\title{
SOEP
}

SOEPpapers

on Multidisciplinary Panel Data Research

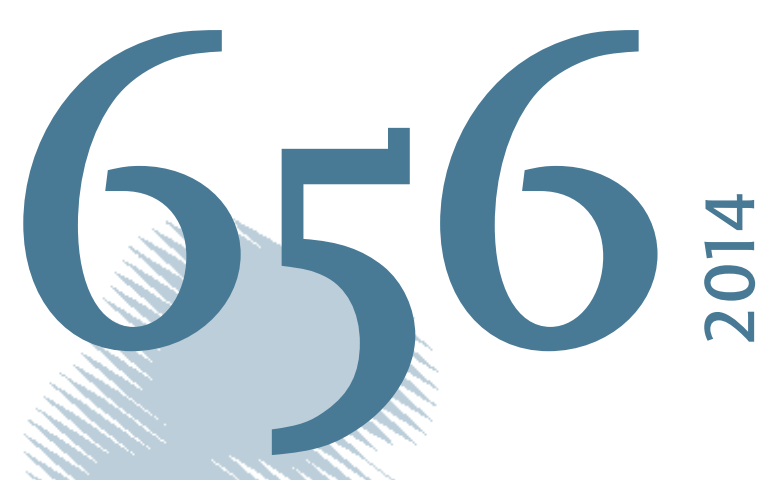

\section{Returns to Citizenship? \\ Evidence from Germany's Recent Immigration Reforms}

Christina Gathmann and Nicolas Keller 


\section{SOEPpapers on Multidisciplinary Panel Data Research}

at DIW Berlin

This series presents research findings based either directly on data from the German SocioEconomic Panel Study (SOEP) or using SOEP data as part of an internationally comparable data set (e.g. CNEF, ECHP, LIS, LWS, CHER/PACO). SOEP is a truly multidisciplinary household panel study covering a wide range of social and behavioral sciences: economics, sociology, psychology, survey methodology, econometrics and applied statistics, educational science, political science, public health, behavioral genetics, demography, geography, and sport science.

The decision to publish a submission in SOEPpapers is made by a board of editors chosen by the DIW Berlin to represent the wide range of disciplines covered by SOEP. There is no external referee process and papers are either accepted or rejected without revision. Papers appear in this series as works in progress and may also appear elsewhere. They often represent preliminary studies and are circulated to encourage discussion. Citation of such a paper should account for its provisional character. A revised version may be requested from the author directly.

Any opinions expressed in this series are those of the author(s) and not those of DIW Berlin. Research disseminated by DIW Berlin may include views on public policy issues, but the institute itself takes no institutional policy positions.

The SOEPpapers are available at

http://www.diw.de/soeppapers

\section{Editors:}

Jürgen Schupp (Sociology)

Gert G. Wagner (Social Sciences, Vice Dean DIW Graduate Center)

Conchita D'Ambrosio (Public Economics)

Denis Gerstorf (Psychology, DIW Research Director)

Elke Holst (Gender Studies, DIW Research Director)

Frauke Kreuter (Survey Methodology, DIW Research Professor)

Martin Kroh (Political Science and Survey Methodology)

Frieder R. Lang (Psychology, DIW Research Professor)

Henning Lohmann (Sociology, DIW Research Professor)

Jörg-Peter Schräpler (Survey Methodology, DIW Research Professor)

Thomas Siedler (Empirical Economics)

C. Katharina Spieß (Empirical Economics and Educational Science)

ISSN: 1864-6689 (online)

German Socio-Economic Panel Study (SOEP)

DIW Berlin

Mohrenstrasse 58

10117 Berlin, Germany

Contact: Uta Rahmann | soeppapers@diw.de 


\title{
Returns to Citizenship? \\ Evidence from Germany's Recent Immigration Reforms
}

\author{
Christina Gathmann \\ Universiy of Heidelberg, CESifo and IZA University of Heidelberg \\ Nicolas Keller
}

This Draft: April, 2014

\begin{abstract}
Immigrants in many countries have lower employment rates and earnings than natives. We study whether the option to naturalize improves immigrant assimilation. The empirical analysis relies on two major immigration reforms in Germany, a country with a weak record of immigrant integration. Using discontinuities in the reforms' eligibility rules, we find few returns of citizenship for men, but substantial returns for women. Returns are also larger for more recent immigrants, but essentially zero for traditional guest workers. For immigrant women, access to citizenship accounts for $70 \%$ of the assimilation rate, i.e. the wage return of an additional year in Germany.
\end{abstract}

\footnotetext{
*Christina Gathmann, Department of Economics, Alfred-Weber-Institut, Bergheimer Strasse 20, 69115 Heidelberg, CESifo and IZA, Email: christina.gathmann@awi.uni-heidelberg.de. Nicolas Keller, Department of Economics, Alfred-Weber-Institut, Bergheimer Strasse 20, 69115 Heidelberg, Email: nicolas.keller@awi.uni-heidelberg.de. We thank Christine Binzel, Christian Dustmann, Zeno Enders, Ben Elsner, Andreas Haufler, Giovanni Facchini, Eckhard Janeba, Astrid Kunze, Panu Poutvaara, Judith Saurer, Albert Solé-Ollé, Massimiliano Tani, Silke Uebelmesser and participants at the University of Mannheim, University of Heidelberg, CESIfo Conference on Public Sector Economics, IZA Research Seminar, the Workshop on Experiments and Quasi-Experiments, the Spring Meeting of Young Economists, EALE and TEMPO Conferences for valuable comments. All remaining errors are our own.
} 


\section{Introduction}

Over recent decades, many developed countries have accumulated sizable immigrant populations. In Europe, for example, the share of foreign-born in 2005 is over $10 \%$ in France, $12 \%$ in Sweden and has reached almost $24 \%$ in Switzerland. These numbers are comparable to the share of foreign-borns in traditional immigrant countries such as Australia, Canada or the United States (OECD, 2006; Hanson, 2009). At the same time, immigrants often seem to perform poorly in the labor market. They have larger unemployment rates and earn substantially less than natives (e.g. Algan et al., 2010; OECD, 2006); in Europe, they often fall short along cultural or political integration as well (Aleksynska and Algan, 2010).

The lack of social and economic integration poses substantial challenges for destination countries. A disadvantaged economic position reduces the fiscal benefit of immigration to the destination country; in ageing societies such as Germany, Italy or Japan, lack of assimilation could also undermine efforts to sustain the current standard of living. Furthermore, exclusion might threaten the social cohesion of host countries producing social unrest and hostility among the native population. While immigrant performance seems to be more successful in traditional immigration countries, the speed of assimilation as well as its underlying mechanisms are still hotly debated (see e.g. Abramitzky et al., 2012; Card, 2005; Borjas, 2013 for some recent US evidence).

As such, the current situation raises a number of very important questions how immigrants may be better integrated into host societies. And which public policies are effective in promoting the economic integration of immigrants? Or, does successful integration hinge on the right "selection" of immigrants by host countries instead? Answers to these questions are crucial for the economic and social well-being of immigrants and destination countries alike.

In this article, we analyze what role citizenship plays for the economic assimilation of immigrants. In particular, does a more liberal access to citizenship improve the economic integration of immigrants in the host country? And what are the mechanisms if citizenship speeds up economic assimilation? Economic theory suggests a number of reasons why citizenship could affect labor market success. First, citizenship is required for a number of public sector or government jobs. To the extent that these jobs offer better pay or working conditions than jobs open to the average immigrant, naturalization would improve labor market performance. A second reason is that employers might not be willing to pay for training of immigrants who stay only for a limited time in the host country (e.g. Lalonde and Topel, 1997). 
In the private sector, employers might also be hesitant to hire a foreign citizen for jobs with extensive traveling abroad due to additional visa costs, for example. In theses cases, citizenship would provide a signal of long-term commitment and reduce existing barriers to career mobility. Most importantly, access to citizenship should also improve the incentives of immigrants to invest in education and language skills in the host country. Better destination-specific skills speed up assimilation as immigrants become more productive on the job or obtain access to new job opportunities (Chiswick and Miller, 1995; Dustmann, 1994; see Dustmann and Glitz, 2011 for a comprehensive survey). Hence, changes in incentives on both the demand and supply side of the labor market suggest that access to citizenship could be an important policy instrument to improve the economic and social integration of immigrants.

Yet, there are also reasons to believe that the benefits of citizenship are overstated. Because naturalized migrants are not selected randomly from the immigrant population, it is challenging to separately identify the return to citizenship from the selection into naturalization. Migrants applying for citizenship might well be those with the highest motivation to integrate and the best prerequisites to perform well in the host country. Previous studies from Canada and the United States, for example, suggest indeed that selection into citizenship is positive with respect to observable skills (see Chiswick and Miller, 2008; Mazzolari, 2009; and Yang, 1994 for the United States; and De Voretz and Pivnenko, 2006 for Canada). A second difficulty facing the researcher is that eligibility to citizenship is often closely tied to the number of years an immigrant has resided in the host country. This close correspondence makes it difficult to separate the returns to citizenship from general assimilation effects in the host country.

To overcome these empirical challenges, we exploit the unique setting in Germany. Today, almost 10 millions foreign-born live in Germany and make up about $13 \%$ of its population. Yet, Germany is an exemplary case for the assimilation and integration problems of immigrants with substantial lower employment and earnings even among second-generation immigrants (e.g. Algan et al., 2010 for recent evidence). Most importantly for our purpose, Germany has substantially liberalized its access to citizenship over recent decades. Traditionally, Germany had a very restrictive citizenship law which was closely tied to ancestry and ethnic origin. Starting in the early 1990s, there have been important changes in Germany's immigration policy. In 1991, the government introduced for the first time explicit criteria how immigrants can obtain German citizenship. Since 2000, immigrants can naturalize after 8 years of residency in Germany, and children of foreign parents in Germany now obtain citizenship at birth. 
To identify the consequences of citizenship for labor market performance, we exploit two institutional peculiarities of Germany's immigration reforms. The 1991 reform defined age-dependent residency requirements for naturalization. Specifically, adult immigrants (aged 23 and above) faced a 15-year residency requirement before they could apply for citizenship. Adolescent immigrants (between 16 and 22) in turn could apply for German citizenship after only 8-year of residence. Hence, immigrants under the age of 23 who arrived in Germany in 1983, for example, became eligible for citizenship right in 1991. Immigrants aged 23 or above who came to Germany in the same year had to wait until 1997 in order to become eligible, or 7 years after the younger cohort. We can therefore compare labor market outcomes of immigrants who are somewhat older or arrived in Germany somewhat earlier and, for this reason, are eligible for naturalization several years earlier than other immigrants. Our analysis then identifies the returns to eligibility (option to naturalize) while being able to control for general assimilation effects and labor market experience.

Our results can be summarized as follows. First, we find that the propensity to naturalize is quite low in Germany even after the liberalization of citizenship. Naturalizations are more common among immigrants from outside the EU member countries and more recent immigrants arriving after the fall of the Berlin wall. Second, our results suggest that selection into citizenship in Germany is intermediate in terms of observable skills for immigrant men and even negative among immigrant women.

Third, accounting for selection into citizenship is important in our case. Once we control for selection into naturalization and general assimilation, we find few, if any effects of naturalization for immigrant men. In line with negative selection into citizenship for women, we find that adjusting for selection increases the wage returns to citizenship. Fourth, we shed light on the mechanisms behind the substantial wage returns for immigrant women. About $30 \%$ of these wage returns is explained by movements across broad occupations and industries. Furthermore, access to citizenship increases job stability: immigrant women are more likely to have a permanent work contract, have higher firm tenure and also work for larger firms after eligibility. In contrast, the wage returns for immigrant women cannot be explained by a higher propensity to work in the public sector, a white collar occupation or a reduction in self-employment; they are also not driven by improved language skills. Overall, we calculate that the returns to citizenship for women explain about $70 \%$ of the overall assimilation rate in Germany.

This article contributes to three strands of the literature. First, we contribute to the literature on naturalization decisions. Most evidence seems to suggest that there is positive selection into citi- 
zenship (Mazzolari, 2009 for the US; Bevelander and Veenman, 2008 for the Netherlands; Steinhardt and Wedemeier, 2012 for Switzerland; Constant et al., 2009 for Germany). We find mixed results for Germany. Men are intermediately selected as the medium-skilled are more likely to naturalize than the low- and high-skilled. Women, in contrast, are negatively selected with respect to education.

Furthermore, our analysis is closely related to studies on the relationship between citizenship and labor market outcomes in the United States or Canada (e.g. Chiswick, 1978; Bratsberg et al., 2002; De Voretz and Pivnenko, 2006) and some European countries (see Bevelander and Veenman, 2008 for the Netherlands; Bevelander and Pendakur, 2011; and Scott, 2008 for Sweden; Fougère and Safi, 2009 for France; Steinhardt, 2012 for Germany). Most studies rely on cross-sectional data comparing naturalized citizens with other immigrants. Recently, a few recent studies employ panel data to estimate whether naturalization improves labor market performance (Bratsberg et al., 2002; Bratsberg and Raaum, 2011; Steinhardt, 2012). We contribute to this literature in three ways: first, we study the effect of legal access to citizenship rather than the individual decision to naturalize. Second, we use arguably exogenous variation in eligibility rules induced by national citizenship reforms to identify the effect of citizenship for labor market performance. Our study therefore does not face the kind of selection problems of earlier, especially cross-sectional studies. Finally, we provide evidence on the benefits of citizenship in a country where naturalization is the exception rather than the norm. Returns to citizenship might differ from those in traditional immigration countries or countries with a long immigration history, such as the UK and France. Taste-based discrimination, for example, might be more widespread in a country where the native population is more homogenous and shares common values or a common religion. Returns to citizenship might then be higher if naturalization eliminates taste-based discrimination in the host country; returns might however, be lower if discrimination is based on foreign-sounding names or appearance rather than citizenship status instead. ${ }^{1}$

Our study also contributes to the literature on immigrant assimilation. A large literature shows substantial native-immigrant wage gaps upon arrival. With time in the home country, immigrants are believed to acquire language skills, better knowledge about job opportunities and get access to social networks thus improving their position in the labor market relative to natives. The size and speed of immigrant assimilation observed in different countries is still hotly debated in the literature (see e.g. Abramitzky et al., 2012; Bell, 1997; Borjas, 1985, 2013; Card, 2005; Clark and Lindley,

\footnotetext{
${ }^{1} \mathrm{~A}$ recent field experiment in Germany suggest that there is some discrimination against immigrants based on foreign-sounding names or foreign accents which are largely independent of citizenship status (Kaas and Manger, 2012).
} 
2009; Duleep and Dowhan, 2002; Hu, 2000; Lalonde and Topel, 1997; Lubotsky, 2007; see Dustmann and Glitz, 2011 for a survey). ${ }^{2}$ For Germany, most studies do not find much evidence for assimilation relative to natives (Pischke, 1993; Dustmann, 1993; Licht and Steiner, 1994; Schmidt, 1997; Bauer et al., 2005; results in Fertig and Schuster, 2007 are mixed). ${ }^{3}$ Our contribution here is twofold: first, we find substantial returns to German citizenship for immigrant women. As such, a more liberal access to citizenship seems one promising instrument to improve the labor market position of immigrants in countries with traditionally restrictive policies. We calculate that access to citizenship accounts for $70 \%$ of the assimilation rate of immigrant women in Germany. Second, we shed light on the possible channels determining assimilation in the labor market in practice: through movements up the occupational ladder, improvements in language skills or economic self-sufficiency. Therefore, our results have direct implications for policy-makers wishing to promote immigrant integration.

This article proceeds as follows. The next section discusses the recent immigration reforms in Germany and outlines our empirical strategy to identify the returns to citizenship. Section 3 introduces our data. Section 4 discusses the determinants of the naturalization decision among immigrants in Germany. Section 5 discusses our results on the returns to citizenship and explores their heterogeneity across immigrant groups. Section 6 presents a number of informal validity checks to test the robustness of our results. Section 7 discusses the policy implications of our findings and concludes.

\section{Institutional Background}

\subsection{A Reluctant Immigration Country}

Almost 10 million foreign-born live in Germany today - or about $13 \%$ of its current population. After World War II, most immigrants, especially from Turkey, Yugoslavia or Italy came to Germany as guest workers. ${ }^{4}$ From the late 1950s until the program was abolished in 1973, the guest worker program actively recruited foreign, mostly low-skilled labor, to meet the growing demand of Germany's booming manufacturing sector. Originally, the guest worker program was intended as a short- to medium-run measure. In practice, however, many guest workers stayed and settled

\footnotetext{
${ }^{2}$ Furthermore, Borjas and Hilton (1996) show that recent immigrants in the United States are more likely to participate in welfare programs than earlier immigrant cohorts.

${ }^{3}$ Basilio and Bauer (2010) argue that lower returns to human capital (education and experience) accumulated abroad can account for most of the native-immigrant wage gap in Germany.

${ }^{4}$ We abstract from war-related refugees from Eastern Europe and East Germany prior to the construction of the Berlin Wall.
} 
down in Germany. ${ }^{5}$ Since the late 1980s and especially after the fall of the Berlin Wall, new waves of immigrants arrived in Germany from Eastern Europe and the former Soviet Union. In the early 1990s, around one million foreigners (about $1 \%$ of its population) arrived in Germany each year. ${ }^{6}$ These immigration rates are comparable to the ones in the United States during the period of mass migration.

Despite substantial inflows of foreign-born, Germany had no explicit naturalization policy at that time. Prior to 1991, German citizenship was closely tied to ancestry (jus sanguinis) as laid down in the law of 1913. Explicit criteria how a foreign-born immigrant without German ancestry would qualify for naturalization did not exist. The official doctrine was that foreigners were only temporary residents in Germany - even though many foreigners had lived in the country for decades. The Federal Naturalization Guidelines of 1977 summarize this official doctrine at the time quite well: "The Federal Republic of Germany is not a country of immigration; it does not strive to increase the number of German citizens by way of naturalization [...]. The granting of German citizenship can only be considered if a public interest in the naturalization exists; the personal desires and economic interests of the applicant cannot be decisive." (Hailbronner and Renner, 1992, pp. 865-6).

\subsection{A New Approach to Citizenship}

The passage of the Alien Act (Ausländergesetz $($ AuslG)) by the federal parliament on April 26, 1990 (and the upper house on May 5, 1990) marked a turning point in Germany's approach to immigration and citizenship. The reform which came into effect on January 1, 1991 defined, for the first time, explicit rules and criteria for naturalization. ${ }^{7}$ Most importantly for our purpose,

\footnotetext{
${ }^{5}$ Their legal status was based on a residence and work permit which became permanent after 5 years and fully unrestricted after 8 years if a person had worked for at least 5 years in a job subject to social security contributions. Close family members could also obtain a residence permit in order to move to Germany. At the same time, the German government used financial incentives to encourage return migration, especially after the end of the guest worker program in 1973.

${ }^{6}$ Many of these were ethnic Germans (i.e. immigrants with some German ancestry), mostly from Eastern Europe and the former Soviet Union, who had access to citizenship within three years of arrival in Germany. Since 1992, the inflow of ethnic Germans is restricted to 220,000 per year. Stricter application requirements (esp. German language requirements) and a reduction in financial assistance further reduced the number of applicants in the late 1990s. While the number of admitted ethnic Germans was 397,000 in 1990, it fell to 222,000 in 1994 and to 105,000 in 1999 (Bundesministerium des Innern, 2008). Below, we drop ethnic Germans from our sample as they are not affected by the immigration reforms we study.

${ }^{7}$ The reform was preceded by more than a decade of intense political discussion that oscillated between the desire to restrict immigration, to encourage return migration and the recognition for social integration of the foreign population already living in Germany. Several reform attempts were made during the 1980s, mostly from left-wing parties, but defeated by the political opposition or influential social groups. The reform in 1991 was pushed on the political agenda by a ruling of the Federal Constitutional Court whether immigrants should be entitled to vote in local elections for foreigners in 1989. The Court ruled those local voting rights unconstitutional but advocated a liberalization of Germany's naturalization policy (see Howard (2008) for a more detailed discussion).
} 
the new law imposed an age-dependent residency requirement. Adults (aged 23 and older) became eligible for citizenship after 15 years of residence in Germany; adolescent immigrants (aged 16-22) in contrast, became eligible after only 8 years. ${ }^{8}$ These residency requirements are still quite restrictive in comparison to other countries. Immigrants in Canada, for example, may naturalize after 3 years of permanent residence, while residency requirements in the United States and many European countries (like the UK, or Sweden) are 5 years - still substantially shorter than the rules imposed by the German reform.

Applicants for German citizenship had to fulfill several other criteria: first, they had to renounce their previous citizenship upon naturalization as the new law did explicitly not allow dual citizenship. Few exemptions to this rule existed at that time. The most important exception covered citizens of the European Union who could keep their citizenship if their country of origin allowed dual citizenship as well. ${ }^{9}$ Second, the applicant must not be convicted of a criminal offense. ${ }^{10}$ Adult immigrants (23 years or older) also had to demonstrate economic self-sufficiency, i.e. they should be able to support themselves and their dependents without welfare benefits or unemployment assistance. Adolescent immigrants (aged 16-22) had to complete a minimum of six years of schooling in Germany, of which at least four years had to be general education. Finally, an applicant needed to declare her loyalty to the democratic principles of the German constitution. Spouses and dependent children of the applicant could be included in the application for naturalization even if they did not fulfill the criteria individually. ${ }^{11}$

The different residency requirements for adult and adolescent immigrants remained in place until

\footnotetext{
${ }^{8}$ See $\S 85$ AuslG (Alien Act) for adolescent immigrants and $\S 86$ AuslG (Alien Act) for adult immigrants. If the applicant stayed abroad for no more than 6 months, the period of absence still counted toward the residency requirement. Temporary stays abroad (between 6 months and 1 year) may still count for the residency requirement. For permanent stays abroad (longer than 6 months), the applicant could count up to five years of residency in Germany toward the residency requirement.

${ }^{9}$ Children of bi-national marriages, for example, did not have to give up their dual citizenship until they turned 18. Other exceptions were granted if the country of current citizenship did not allow the renunciation of citizenship or delayed the renunciation for reasons outside the power of the applicant; if the applicant was an acknowledged refugee or if the renunciation imposed special hardships on older applicants. In practice, few exceptions to the general rule were granted in the 1990 s.

${ }^{10}$ Applicants with minor convictions, such as a suspended prison sentence up to 6 months (which would be abated at the end of the probation period), a fine not exceeding 180 days (calculated according to the net personal income of the individual), or corrective methods imposed by juvenile courts, were still eligible. Convictions exceeding these limits were considered on a case-by-case basis by the authorities.

${ }^{11}$ Similar criteria are found in other countries. Overall, they seem to play a subordinate role for the naturalization process. A survey of eligible immigrants by the Federal Office of Migration and Refugees showed that the majority of migrants had good knowledge about the naturalization criteria. Of those, $72 \%$ reported that they fulfilled all requirements completely while $23 \%$ reported to meet most, though not all of the criteria (BAMF, 2012). As such, rejection of applications for citizenship based on criteria other than residency requirements should not be a major concern. If anything, this would bias our estimates downward as we would define an immigrant as eligible (based on the residency requirement) even though she is not (based on one of the other eligibility criteria).
} 
the second important reform came into effect on January 1, 2000. The Citizenship Act (Staatsangehörigkeitsgesetz (StAG)) reduced the residency requirement to 8 years irrespective of the immigrant's age. ${ }^{12}$ The other requirements of the 1991 reform remained in place: applicants could not have a criminal record, had to demonstrate loyalty to democratic principles and economic self-sufficiency. In addition, the new law also required applicants to demonstrate adequate German language skills prior to naturalization. As before, the law of 2000 did not recognize dual citizenship in general though exemptions became more numerous in practice. ${ }^{13}$ The 2000 reform further introduced elements of citizenship by birthplace into German law. A child born to foreign parents after January 1, 2000 was eligible for citizenship if one parent had been a legal resident in Germany for 8 years and had a permanent residence permit for at least three years. Since our analysis focuses on first-generation immigrants, our sample is not directly affected by the jus soli provisions of the 2000 reform. ${ }^{14}$

The liberalization of citizenship law after 1991 and again after 2000 is reflected in the number of naturalizations in Germany. Prior to the first reform, only about 34,000 persons became naturalized on average each year (see Figure 1). After the immigration reform in 1991, naturalizations jumped to 230,000 per year. After the second reform in 2000, the number of naturalizations was with 137,000 per year actually lower than in the 1990s though higher than in the pre-1991 period. Scaled by the first-generation immigrant population, the propensity to naturalize in Germany is still low compared to traditional immigrant countries. Among immigrants with more than 10 years of residency, about 35-40\% became German citizens; for comparison, the share is about $60 \%$ in the United Kingdom and over $80 \%$ in Canada (OECD, 2011).

\footnotetext{
${ }^{12}$ The law was adopted with a large majority in the lower house on May 7, 1999 and the upper house on May 21, 1999. The provisions are laid down in $\S 10$ Abs. 1 StAG (Abs. 2 for spouses and dependent children of eligible immigrants), which form the basis for over $80 \%$ of all naturalizations in Germany (BAMF, 2008). Additional ways to naturalize are laid down in $\S 8$ (naturalizations based on a discretionary decision of the authorities because of "public interest") and $\S 9$ (naturalization for spouses of German citizens who face a reduced residency requirement of 3 years).

${ }^{13}$ In addition to citizens of the EU member states, it became easier for older applicants and refugees to keep their previous citizenship. Applicants could also keep their nationality if it was legally impossible to renounce it or if it imposed a special hardship like excessive costs or serious economic disadvantages (e.g. problems with inheritances or property in their country of origin).

${ }^{14}$ See Avitabile et al. (2013a; 2013b) for an analysis of the jus soli provisions of the 2000 reform. There might be an indirect effect on first-generation immigrants, however. Before the 2000 reform, second- or third-generation immigrants could only become naturalized if their parents applied for citizenship. After the 2000 reform, young children had access to German citizenship independently of their parents' decision (subject to the residency requirements outlined above). Hence, the reform of 2000 might have actually decreased the inter-generational benefits of citizenship for foreign parents with young children. We return to this issue below.
} 


\subsection{Using the Eligibility Rules of the 1991 and 2000 Reforms}

Can a more liberal access to citizenship promote economic integration, even in a country with little tradition of naturalizations? To answer this question, we cannot simply compare the labor market outcomes of naturalized immigrants with those not naturalized because the decision to naturalize is endogenous. We now sketch how we use the discontinuities in the eligibility rules after the 1991 and 2000 reforms to identify the benefits of citizenship.

To illustrate the discontinuity created by the 1991 reform, consider two immigrants who arrive in Germany in 1983. The first immigrant is 15 years-old (born in 1968), while the second immigrant is 14 years old (born in 1969). When the reform comes into effect in 1991, both immigrants have lived in Germany for 8 years. The younger immigrant is 22 years-old and can therefore apply for citizenship in 1991, whereas the older immigrant is 23 years-old and can only apply for citizenship in 1998. As a result, the younger immigrant is eligible 7 years earlier than the older immigrant - though both are of similar age and have lived in Germany for the same number of years. Figure 2 illustrates when different arrival cohorts are eligible for German citizenship following the two immigration reforms. For immigrants arriving between 1976 and 1983, for instance, adolescents (ages 16-22) can naturalize in 1991, adult immigrants only between 1991 and 1996, i.e. 1 to 6 years later. After 2000, all immigrants older than 16 and arriving in Germany in 1992 or later become eligible after 8 years of residency. Hence, we can exploit three types of variation in eligibility status created by the reforms to identify the returns to citizenship: first, adolescent immigrants arriving in Germany between 1976 and 1983 get eligible immediately after the first immigration reform in 1991. Second, we can compare outcomes of adolescent and adult immigrants who arrive in Germany between 1976 and 1991 and get eligible in different years in the 1991-1999 period. The third type of variation arises because all adult immigrants arriving in Germany between 1985 and 1992 get eligible with the 2000 reform. ${ }^{15}$

\footnotetext{
${ }^{15}$ In principle, we could use the variation to implement an RDD estimator where we use immigrants of similar age and years in Germany left and right of the eligibility threshold. However, no data source is suited for such this empirical approach. The IAB data based on social security records does not contain the year when a foreign citizen first moved to Germany. The Microcensus prior to 2005 does not contain reliable information on actual naturalization; furthermore, the sample sizes are too small to identify a truly local estimate of citizenship eligibility. Therefore, we implement below a reduced form estimator of the returns to citizenship eligibility within a homogeneous sample of immigrants.
} 


\section{Data Sources}

\subsection{Microcensus}

Our main data source to study naturalization and its consequences for labor market performance is the German Microcensus, a repeated cross-sectional survey of a $1 \%$ random sample of the German population. It covers detailed questions about individual socio-demographic characteristics, employment, personal income, and the household. The main advantages of the Microcensus are the large samples of foreigners (about 50,000 per year) as well as detailed and precise information on years spent in Germany and the acquisition of German citizenship.

For each foreigner we know whether he or she was born in or outside of Germany. We restrict our sample to first-generation immigrants, i.e. immigrants born outside of Germany. We also need to drop ethnic Germans who had faster access to citizenship and therefore are not affected by the 1991 and 2000 immigration reforms. To do so, we restrict our analysis to the 2007-2009 survey years since the survey asks since 2007 whether an immigrant is naturalized as an ethnic German. To make our sample even more homogeneous, we further restrict the analysis to immigrants arriving in Germany between 1976 and 2000 who were 16 -35 years-old in the post-reform period. ${ }^{16}$

The Microcensus also reports whether an immigrant has obtained German citizenship and the year in which naturalization took place. Based on this information, we define the number of years since an immigrant obtained German citizenship. To define eligibility for citizenship, we calculate the number of years since an immigrant is eligible using the immigrant's year of arrival and year of birth. ${ }^{17}$ The naturalization and eligibility variables are zero before an immigrant becomes eligible for German citizenship and equal to the number of years since an immigrant has naturalized or become eligible thereafter.

Our main outcome variables of interest are log personal income and employment. The variable is measured as net personal income per month and is deflated by the national consumer price index. Employment is an indicator equal to one if the immigrant pursues any income-generating activity

\footnotetext{
${ }^{16}$ A potential issue of this approach is that only immigrants who survive until the survey year are in the data. However, our analysis focuses on individuals aged 16 to 35 in the 1991-2009 period. We therefore think that survivor bias is not an issue here.

${ }^{17}$ We abstract from other eligibility criteria largely because we do not have any information (e.g. about the criminal record) or because it is unclear how the criteria is applied (e.g. economic self-sufficiency). As a consequence, we are likely to misclassify a few immigrants who satisfy the residency requirements but are not eligible according to some other criteria. This misclassification will result in a downward bias of eligibility on naturalization propensities (as some individuals, which we classify as eligible, cannot naturalize in practice). If immigrants with a criminal record and economic dependence have worse labor market outcomes than eligible immigrants, our estimates of the benefits of German citizenship are downward biased. Consequently, classification errors should produce conservative estimates in our analysis below.
} 
in the week before the interview and zero otherwise. We also analyze economic self-sufficiency, i.e. whether an immigrant receives social assistance payments. The main control variables are the number of years in Germany, age, gender and education. We distinguish between low-skilled (no high school or vocational degree), medium-skilled (a higher school degree or a vocational degree) and high-skilled immigrants (with a college degree).

To study heterogeneity in returns to citizenship by country of origin, we distinguish between immigrants from the traditional EU-15 member states (e.g. Italy or Portugal), immigrants from countries that recently joined the European Union (the so-called EU-12, e.g. Poland or the Czech Republic), immigrants from Turkey, ex-Yugoslavia (except Slovenia) and the Former Soviet Union (except the Baltic states). We lump together other immigrants into broad regions of origin (Asia, Africa, the Middle East and North or South America). In addition, we analyze whether the returns to citizenship differ for immigrants from high- and low-income countries using data on GDP per capita in the country of origin in 2005 from the Penn World Tables (Heston et al., 2011). Table A1 shows summary statistics of our sample of first-generation immigrants in the Microcensus. Further details on the definition of our sample and each variable is contained in the data appendix.

\subsection{Socio-Economic Panel}

To study additional outcomes and shed light on the decision to naturalize, we use the Socio-Economic Panel (SOEP, 2010). The SOEP is an annual panel interviewing more than 20,000 individuals about their labor supply, income and demographic characteristics since $1984 .{ }^{18}$ As in the Microcensus, our basic sample consists of all first-generation immigrants who arrived in Germany between 1976 and 2000 and are between 16-35 years-old in the post-reform period.

We define naturalization based on observed changes in the citizenship recorded. The variable is equal to zero as long as an immigrant reports a foreign nationality and one in all years when a German citizenship is recorded. We perform several consistency checks (outlined in the data appendix) to ensure that individuals do not change their citizenship more than once. Based on the information about current citizenship, we define the number of years since an immigrant actually naturalized. Using the residency requirement, we define an indicator for citizenship eligibility which is equal to one if (1) an individual has been in Germany for at least 8 years and is between 16 and 22 years old for all years after 1990; (2) if an immigrant has been in Germany for at least 15 years and is 23 years old or above in the 1991-1999 period; or, (3) if an immigrant has been in Germany for

\footnotetext{
${ }^{18}$ Wagner, Frick and Schupp (2007) provide a comprehensive description of the dataset.
} 
at least 8 years and is 23 years old or above in 2000-2009. The indicator is zero if a first-generation immigrant is not (yet) eligible for naturalization in a year. We define the number of years since an immigrant became eligible for German citizenship in a similar fashion.

Our main dependent variable is the log of monthly gross labor earnings deflated with the national consumer price index. Labor force participation is an indicator equal to one if an immigrant works in any type of employment; the indicator is zero if she is unemployed or out of the labor force. We further study self-reported language skills in writing or speaking German (recoded to range from $0=$ not at all to $4=$ very well). Our main control variables are age, years spent in Germany and education (which are coded as in the Microcensus). Table A2 shows summary statistics for our sample of first-generation immigrants in the SOEP.

\section{The Determinants of Naturalizations in Germany}

\subsection{Empirical Approach}

We begin with an analysis of the decision to naturalize after the 1991 and 2000 reforms. To do so, we estimate variants of the following model:

$$
\operatorname{Prob}\left(\text { Naturalize }_{i t}=\alpha+\beta \text { Eligible }_{i t}+\gamma_{1} Y r \sin G_{i t}+\gamma_{2} Y r \sin G_{i t}^{2}+\delta X_{i t}+\mathrm{t}_{t}+\lambda_{s}+\vartheta_{s}{ }^{*} \text { year }_{t}+\varepsilon_{i t}\right.
$$

where the dependent variable is equal to one if an individual is naturalized in year $t$ and zero otherwise. Our main parameter of interest is $\beta$ which measures how eligibility for naturalization affects the decision to naturalize. Note that this effect is identified by comparing immigrants who just became eligible for naturalization to immigrants who are not (yet) eligible for naturalization.

Equation (1) includes a linear and squared term of years spent in Germany to capture general assimilation among all immigrants. We also control for immigrant characteristics like age, age squared and education. To adjust for aggregate changes and local economic conditions, we add year and state fixed effects as well as state-specific linear trends. Finally, we include region of origin fixed effects to capture different propensities to naturalize across source countries. ${ }^{19}$ All models are estimated separately for male and female immigrants. Note that we control in equation (1) for all

\footnotetext{
${ }^{19}$ Since we are primarily interested in the effects of naturalization on the labor market performance of immigrants, we choose this rather reduced form approach instead of including detailed controls for the source country (as in Chiswick and Miller, 2008, for example). Clearly, there might be other factors determining the decision to naturalize, for example, the presence of children or close family members in the source country who might have easier access to visa or citizenship after a family member has naturalized in the host country.
} 
variables that also define eligibility (age, years in Germany and year). A regression of the eligibility indicator in the SOEP on all control variables outlined above yields a R2 of 0.7 (women) and 0.72 (men). A similar regression in the Microcensus yields a R2 of 0.57 (for men and women). Hence, we still have variation in our eligibility variables to identify the benefits of citizenship even controlling for general assimilation and age effects. For the analysis, we cluster the standard errors at the age $\mathrm{x}$ immigration year level to adjust for the level of aggregation in the eligibility variable.

\subsection{The Decision to Naturalize in Germany}

Table 1 shows the results of estimating equation (1) with a linear probability model using the SOEP. Consistent with the low naturalization numbers in the official statistics, we find that eligibility after the 1991 and 2000 reforms has a rather weak effect on the decision to naturalize. Eligibility increases the likelihood of naturalization by 6 percentage points for men and 13 percentage points among women. Once we control flexibly for years since immigration, the effect is about 4 percentage points for men and 5 percentage points for women. ${ }^{20}$ One explanation for the low takeup rates is certainly that Germany has been reluctant to accept dual citizenships. Immigrants who plan to return to their home country some day might face disadvantages (e.g. buying or inheriting property as in Turkey, for example) without their original citizenship. Having to renounce the original citizenship could then be one channel why takeup of German citizenship is low.

As argued in the introduction above, the benefits of naturalization, and hence incentives to naturalize, might be stronger for immigrants from outside the European Union. Therefore, we explore next whether the propensity to naturalize differs by country of origin. The evidence indeed suggests that male immigrants from the Middle East, Africa, America, Asia as well as Turkey and exYugoslavia have a much higher propensity to naturalize than immigrants from EU member countries (EU-15 plus the new EU-12). For female immigrants, we see overall a pattern similar to that for men. In addition, female immigrants from EU-12 and the Former Soviet Union are more likely to obtain German citizenship than immigrants from the traditional EU-15 member states.

Table 1 also sheds some light on the selection into citizenship in Germany. In contrast to traditional immigration countries, age has no effect on the propensity to naturalize for male immigrants;

\footnotetext{
${ }^{20}$ One might be worried that some immigrants are more likely to exit the population because of emigration or death. Our analysis of selective dropout in Table A3 suggests that those who eventually naturalize are about 1 percentage point less likely to exit the population. In contrast, we find no correlation between naturalization or eligibility in the current year and dropout. As a consequence, we think this issue is not a major concern. Constant and Massey (2002) show that emigrants from the SOEP have somewhat less stable employment histories but find no selectivity with respect to education or earnings.
} 
for women, we find that younger immigrants are more likely to naturalize. ${ }^{21}$ Even more interestingly, we find no evidence for positive selection in terms of educational attainment. Medium-skilled immigrants are about 3-4 percentage points more likely to naturalize than the low-skilled reference group. High-skilled immigrants are, however, no more likely (male immigrants) or even 4-6 percentage points less likely (female immigrants) to naturalize than the low-skilled. This result is quite surprising because studies from other countries typically find a positive selection into citizenship (see Chiswick and Miller, 2008 and Yang, 1994 for the US; or Fougère and Safi, 2008 for France). We think that European integration is the likely explanation for the non-positive selection into citizenship in Germany. Immigrants from EU member countries have in principle access to the same jobs as natives. At the same time, EU immigrants are on average more skilled than the average immigrants from outside the European Union. Hence, relatively skilled individuals from EU member countries have less incentives to naturalize than immigrants with less privileged access to the labor market and residency permits.

To probe the robustness of these results, we re-estimate equation (1) using a probit model or, alternatively, lagged (rather than current) eligibility status to allow for some delay in the process of naturalization. Conditional on years in Germany, marginal effects in the probit model are similar to those reported in Table 1. Results using lagged eligibility are statistically weaker for men and marginally stronger for female immigrants (see Table A4).

We can also use the larger samples of the Microcensus to study naturalization decisions. To do so, we first convert the Microcensus into a pseudo-panel spanning the 1985-2009 period. ${ }^{22}$ Results for the Microcensus pseudo-panel in Table A5 largely confirm the SOEP results. Eligibility increases the decision to naturalize by $5-6$ percentage points for men and women. The effects decrease to 3-4 percentage points (but remain statistically significant) if we adjust for general assimilation effects. ${ }^{23}$ As in the SOEP, we find evidence for intermediate and negative selection into citizenship and large differences by source countries. Immigrants from Africa, Asia, Middle Asia, Turkey and ex-Yugoslavia are much more likely to naturalize than immigrants from EU member countries.

\footnotetext{
${ }^{21}$ Our evidence is in line with Constant et al. (2009) who use the SOEP to study naturalization decisions in Germany. Evidence from traditional immigration countries suggests instead that older immigrants are more likely to naturalize even conditional on years since immigration (Chiswick and Miller, 2008 for the United States; De Voretz and Pivnenko, 2006 for Canada).

${ }^{22}$ We create an indicator equal to one if an immigrant has naturalized in any year between 1985 and 2009 from the reported year of naturalization. We calculate age in the 1985-2000 period using information on the year of birth; and eligibility for naturalization in any year between 1991 and 2009 from information on age and year of arrival in Germany. Finally, we assign education based on the information recorded in 2007-2009; here, education refers to the highest educational degree attained rather than the education level in a particular year.

${ }^{23}$ We find similar, though slightly weaker effects if we include individual fixed effects.
} 
Does the propensity to naturalize also differ between guest workers and their family members (who came to Germany prior to the fall of the Wall) and more recent immigrants (arriving after the fall of the Berlin Wall)? Table A6 indeed shows striking differences in the propensities to naturalize between the two groups. Guest workers and their family members are much less likely to naturalize than more recent immigrants. For both groups of immigrants, the younger are more likely to naturalize. We again find intermediate selection with respect to education: the medium-skilled, but not the high-skilled, naturalize more than the low-skilled. Finally, more recent immigrants outside the EU are more likely to naturalize than immigrants from the European Union (both EU15 members and the new EU-12 states); there is much less heterogeneity across sending countries for more traditional immigrants.

In sum, the evidence supports the idea that eligibility rules have an impact on actual naturalization behavior. At the same time, the propensity to naturalize in Germany is quite low on average, though higher for immigrants outside the European Union. We also show that, in sharp contrast to traditional immigrant countries like Canada or the United States, selection into citizenship in terms of education is intermediate for men but actually negative for women. We now turn to the question whether access to citizenship affects labor market performance.

\section{Citizenship and Labor Market Performance}

\subsection{Empirical Strategy}

To identify the effect of obtaining German citizenship on labor market outcomes, we estimate variants of the following model:

$$
Y_{i a b t}=\alpha+\beta \text { Treat }_{i a b t}+\gamma_{1} Y r \sin G_{a t}+\gamma_{2} Y r \sin G_{a t}^{2}+\mu_{1} A g e_{b t}+\mu_{2} A g e_{b t}^{2}+\delta X_{i t}+\vartheta_{t}+\lambda_{s}+\varepsilon_{i a b t}
$$

where $Y_{\text {iabt }}$ is the labor market outcome of immigrant $i$ (who arrived in Germany in year $a$ and

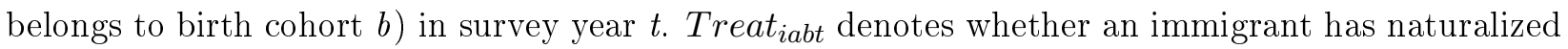
or alternatively is eligible for naturalization. We control for labor market assimilation which occurs independently of naturalization and general labor market experience (both linear and quadratic). We further include the immigrant's skill, region of origin, year and state fixed effects as well as state-specific year trends to adjust for local labor market conditions and aggregate economic shocks.

The main parameter of interest is $\beta$. In the baseline OLS specification, the coefficient measures 
how actual naturalization is related to labor market performance above and beyond general labor market assimilation and returns to human capital. Our main focus is, however, on the reduced-form specification which identifies whether legal access to citizenship improves labor market outcomes among immigrants. We focus on the reduced-form, i.e. the intent-to-treat effect, for two reasons. First, knowing whether a more liberal access to citizenship affects labor market outcomes is important in its own right. The policy effect is the primary parameter of interest for policy makers who aim to improve the economic integration of immigrants in the host country. Second, the evidence in Section 4 suggests that the immigration reforms have a rather modest effect on the propensity to naturalize in Germany. Yet, the reduced-form estimator remains unbiased and consistent even in the presence of a weak first stage. ${ }^{24}$

The reduced-form coefficient is identified from comparing immigrants of the same age who arrived in slightly different years (but get eligible after the immigration reforms in 1991 and 2000); or from comparing immigrants who arrived in the same year, but at somewhat different ages (and therefore get eligible under the rule for adolescent or adult immigrants). The identifying assumption here is that conditional on all our control variables the labor market outcomes of an immigrant who is not yet eligible for naturalization (e.g. because she arrived in Germany somewhat later or was a bit older) is a valid counterfactual for the labor market outcomes of an immigrant eligible for naturalization. This identifying assumption would, for example, be violated if treatment and control groups differ in their pre-reform characteristics; or, if the labor market outcomes of treatment and control group exhibit differential trends prior to the immigration reforms. We find no systematic evidence that our identifying assumption is not valid. We report these tests of our identifying assumption and several other validity checks after we present our main results.

For the analysis of labor market effects, we mostly rely on the Microcensus because it has much larger samples and more accurate information on naturalization. A potential disadvantage of the Microcensus is that we observe labor market outcomes only several years after immigrants actually naturalize or are eligible. Estimation of equation (2) therefore identifies persistent growth effects of naturalization or eligibility. Yet, the Microcensus would not identify a level effect immediately with naturalization or eligibility. The reason is that the control group of immigrants also qualifies for citizenship during our sample period (though later than the treatment group) and would have

\footnotetext{
${ }^{24}$ We could use the eligibility criteria to construct a supplementary instrumental variable approach. Using eligibility as an instrument for actual naturalization, we still find a positive wage return for women and no return for men. The first stage, however, is rather weak especially for men which likely generates biased IV estimates. We therefore focus our analysis on the reduced-form.
} 
experienced the same upward (or downward) shift in wage levels by 2009 (see Figure A1 for an illustration). Our robustness analysis suggests, however, that naturalization mainly works through growth effects (and not level effects). As such, our focus on the longer-run performance of immigrants is not a limitation of the current study. A potential advantage of focusing on long-run outcomes is that our estimates are less likely to be affected by any transitory shocks around the reform years.

\subsection{Naturalization, Eligibility and Labor Market Performance}

Table 2 shows OLS results for employment and log monthly personal income in 2007-2009. The OLS results suggest that an additional year as a German citizen is associated with both higher employment rates (by about $0.3 \%$ ) and higher earnings (by about $0.7 \%$ ). The correlation becomes slightly weaker, but remains robust when we control for years spent in Germany. Conditional on occupation and sector dummies, the correlation declines by $60 \%$ and even becomes statistically insignificant for female immigrants (see columns (5) and (10)). Thus, a substantial share of the correlation between naturalization and earnings, especially for women, seems to work through occupational upgrading and selection into higher-paying industries after getting naturalized as a German citizen. In line with the previous literature, there is little evidence of assimilation for immigrant men in Germany. We find, however, positive assimilation among immigrant women which have not been documented before. We also find large age effects, especially for immigrant men, in part because we focus on a young immigrant sample who are still on the steep part of their age-earnings profile.

If immigrants select into German citizenship based on unobservable characteristics, the correlation between actual naturalization and labor market outcomes may be misleading. In most countries with a long immigration history, naturalized immigrants seem to be positively selected in terms of observable and possibly unobservable skills like motivation etc. In that case, we would expect that OLS estimates overstate the true return to citizenship. In the German context, we find evidence for intermediate selection with respect to education for male immigrants. For female immigrants, we actually find support for negative selection into citizenship. Returns to citizenship would then be larger than the OLS estimates suggest.

To identify returns to citizenship net of selection effects, Table 3 shows the intent-to-treat effect of citizenship on labor market performance. Generally, we find no effect of citizenship on employment rates for both men and women. For male immigrants, there is also no wage return to German citizenship once we control for years in Germany. Female immigrants in contrast, have an annual wage return of $1.4 \%$. Even accounting for sorting across broad occupations and sectors, wage growth 
is still $1 \%$ higher after becoming eligible for citizenship. Hence, about $30 \%$ of the wage return for women is explained by changes to higher-paying occupations and sectors. Consistent with negative selection in terms of unobservables, we find that the reduced-form returns for women are larger than the OLS estimates. These results suggest that women gain substantially from the liberalization of citizenship laws in Germany.

We further explore whether naturalization is related to economic self-sufficiency. We measure self-sufficiency through an indicator equal to one if an immigrant receives unemployment benefits or social assistance in the current year. Immigrants can claim both benefits irrespective of their citizenship as long as they have a valid work permit. OLS estimates suggest that naturalized immigrants are less likely to receive welfare benefits (see Table 4). The reduced-form estimates tell a somewhat different story: the likelihood to receive social assistance is higher among eligible immigrants than among those not yet eligible. While the estimates are similar, they are statistically significant for men only. Table 4 further suggests that men are indeed more likely to draw welfare benefits (rather than unemployment assistance). We think there are two possible interpretations of this pattern: one based on eligibility and one based on information. Recall that one of the criteria for naturalization is that immigrants demonstrate economic self-sufficiency. If immigrants are well informed about these rules, they might try to avoid drawing welfare benefits in order not to jeopardize their chances of naturalization. A second interpretation of the higher propensity to draw welfare benefits is that immigrants are not well-informed about the welfare system in Germany. Only when they qualify for citizenship or after naturalization do they learn about the availability (or their eligibility for) welfare benefits and may make use of them afterward.

\subsection{Potential Mechanisms}

What explains the wage returns to citizenship for women? Naturalization might, for instance, have an impact on the type of job or occupation immigrants work in. Theories of naturalization suggest that citizenship provides access to certain jobs in the public sector. In addition, naturalized immigrants might have better chances of moving up the job ladder, for example by switching from a blue collar to a white collar job; or, allowing them to leave self-employment with low pay. Table 5 explores whether citizenship affects the type of job held by immigrants.

OLS estimates (top panel) suggest that naturalized immigrants are more likely to work in the public sector or in a white collar job. The reduced-form effects (bottom panel) in contrast show no effect on working in the public sector or in a white collar occupation conditional on time spent 
in Germany. Hence, the fact that more naturalized immigrants work in white-collar occupations or are employed in the public sector is driven by unobserved heterogeneity that is correlated both with the decision to naturalize and employment in the public sector or a white-collar occupation. For example, one could imagine that a highly risk averse immigrant, say from a politically unstable source country, has a strong preference to naturalize and at the same time has a strong preference for the job security offered in the public sector.

The results in Table 5 further show that occupational upgrading among female immigrants (see Table 3) cannot be explained by higher rates of employment in the public sector or white collar jobs. Instead, the wage returns seem to be largely the consequence of moving to higher-paying blue-collar occupations within the private sector. We also find no evidence that self-employment decreases (or increases) after becoming eligible for citizenship.

The final two specification in Table 5 show that both male and female immigrants are somewhat more likely to have a permanent work contract and have more stable job histories. The size of the effect, for example, is very small (about $0.5 \%$ ) given that more than $80 \%$ report having a permanent work contract. To investigate the sources of the wage returns further, Table A7 uses the SOEP data to explore whether immigrants are more likey to switch jobs or work in larger firms after eligibility. The results confirm that immigrants are somewhat less likely to switch jobs, occupations or industries after access to citizenship though the effects are quite small. We also find that women (but not men) work in larger firms after eligibility. Hence, the wage return for women is also attributable in part to a firm size effect (as larger firms pay higher wages).

Since citizenship grants immigrants a long-time perspective in the destination country, it should increase incentives to invest in host-country skills such as the native language. Table 6 suggests positive correlations between actual naturalization and German language ability for both male and female immigrants. Controlling for years spent in Germany cuts the correlation in half to about 0.1 and 0.2 of a standard deviation. Once we control for selection using eligibility rather than actual naturalization, we find no improvements in language skills among male and female immigrants in Germany. If anything, there is some evidence that the ability to speak German declines somewhat for men and women. ${ }^{25}$ Other control variables (not shown) have the expected effect: more educated

\footnotetext{
${ }^{25}$ As language skills are self-assessed, we cannot rule out that immigrants' assessment of their own language skills is affected by naturalization or eligibility for citizenship. Naturalized immigrants might see their language skills in an over-optimistic light after obtaining citizenship; such over-optimism would bias the OLS estimates upward. Dustmann and van Soest (2001) have shown for instance, that there is substantial measurement error when individuals self assess their language skills repeatedly in a panel survey. Yet, to account for the strong positive correlation for naturalized immigrants jointly with the negative effects for eligible immigrants, we would require an optimism bias in the first case but an overly pessimistic view in the second case.
} 
immigrants have better language skills as do immigrants who have lived in Germany longer. ${ }^{26}$ We interpret these results as evidence that language skills improve primarily with time in Germany rather than through citizenship alone.

\subsection{Heterogeneity of Effects}

So far we have found little evidence that German citizenship has any returns in the labor market for men while the returns are sizable for women. This average effect might mask substantial heterogeneity in the returns across immigrant groups. Since the propensity to naturalize varies a lot with the country of origin, we might expect that some immigrants also benefit more from citizenship than others in the labor market. Focusing on reduced-form estimates, Table 7a (for men) and Table 7b (for women) document substantial heterogeneity in the returns to citizenship. Male immigrants from the Middle East, Asia and the Former Soviet Union have positive wage returns of 2-3\% higher per year. All other immigrant groups, including immigrants from EU member states, have no wage returns to citizenship. For women we find that immigrants from the EU-12, ex-Yugoslavia, Middle East, Asia and the Former Soviet Union have positive wage returns ranging from 1.5-2.3\% per year.

To analyze this heterogeneity more systematically, we explore whether immigrants from poorer countries benefit more from naturalization. We merge information on the GDP per capita in the source country in 2005 from the Penn World Tables (Heston et al., 2011) and interact the eligibility indicator with the GDP per capita in the immigrant's source country. ${ }^{27}$ Immigrants from richer countries have higher wages overall. Yet, immigrants from poorer countries have higher wage growth after citizenship than immigrants from richer source countries (see columns (3) and (4) of Table 7a and $7 \mathrm{~b}$ ). Going from relatively rich Italy to poor Afghanistan, for instance, roughly doubles the return to citizenship. The return of an additional year of citizenship increases wages for men from -0.007 to +0.008 ; for women, the return increases from 0.011 to $0.02 .^{28}$ In contrast, we do not find evidence that returns to citizenship differ across education levels. ${ }^{29}$

Finally, the returns to citizenship might vary across arrival cohorts, in particular between tra-

\footnotetext{
${ }^{26}$ In 2005, Germany introduced mandatory integration courses which also include German language instruction. Our results become actually slightly stronger if we restrict our data set to the years prior to 2005 .

${ }^{27}$ The number of observations for this specification is lower because we can merge GDP data only with immigrants for which we observe the actual country of origin (e.g. Turkey), not only the region of origin (e.g. Asia).

${ }^{28}$ In 2005, Italy's GDP per capita was 26,155 Euros, while Afghanistan had a GDP per capita of 619 Euros. Taking the main effect and interaction effect of columns (4) in Table 6a (for men) and Table 6b (for women), the return for an Italian men is $0.0053-0.0006^{*} 26.155=-0.0074$. A male immigrant from Afghanistan in turn gets $0.0053-$ $0.0006 * 0.619=0.0075$. For women, the return for an Italian immigrant is calculated as: $0.0202-0.0004 * 26.155=0.0108$; for an Afghan immigrant, the return is: 0.0202-0.0004*0.619=0.0199.

${ }^{29}$ We also check whether citizenship affects female employment especially for women from countries with low female labor force participation rates; however, we do not find any evidence for any convergence in employment.
} 
ditional guest workers (arriving prior to 1990) and more recent immigrants (arriving after the fall of the Berlin wall). More recent immigrants to Germany are more likely to come from Eastern Europe, especially ex-Yugoslavia and the former Soviet Union, than traditional guest workers. We find striking differences. As shown in Table 8, male immigrants arriving in Germany before 1990 have zero returns to citizenship, while more recent immigrants have substantial positive returns to naturalization. For women, there are positive returns to citizenship for both guest workers and recent immigrants though the returns for more recent immigrants are larger.

One interpretation of this heterogeneity would be that the economic and social environment in Germany has turned in favor of immigrants. However, reduced discrimination or other more favorable attitudes of natives toward immigrants would only explain our results if immigrants who arrived recently in Germany benefit from it while more traditional immigrants do not. In addition, the more favorable treatment has to be restricted to immigrants eligible for citizenship, but cannot benefit immigrants who get eligible for German citizenship somewhat later. We think this scenario is unlikely. An alternative explanation would be that immigrants arriving in Germany after 1990 knew that they can obtain citizenship whereas earlier guest workers came to Germany without any such long-term perspective. As such, incentives to migrate and invest in destination-specific skills might have changed after the 1991 and the 2000 reforms. At the same time however, immigrants arriving after 1990, many from Central and Eastern Europe, are on average younger and slightly more educated than traditional guest workers. Their somewhat better human capital endowment could then be the primary reason why recent immigrants benefit more from citizenship. Due to the timing of the reforms, we cannot separate whether the change in immigrant selection after 1991 is a consequence of different incentives alone, or a consequence of the new immigration opportunities after the Iron Curtain was removed.

\section{Robustness Analysis}

This section explores the robustness of the estimated returns to citizenship and the validity of our identifying assumption. Our first specification runs separate regressions for EU and non-EU immigrants because theory suggests that incentives to assimilate and invest in host-country skills are larger for non-EU immigrants. Interestingly, we find little difference in wage returns: the returns to eligibility are essentially zero for men in both samples and sizeable for both EU and non-EU immigrant women. 
Another concern of our analysis so far is that some immigrants in our sample might qualify for citizenship through alternative channels. The most important fast track to citizenship is through being married to a German citizen. Foreign spouses of citizens can apply for naturalization after 3 years of residency in Germany. ${ }^{30}$ Therefore, some of the immigrants in our sample would be eligible for naturalization much faster than our eligibility variable indicates. Naturalization through marriage is expected to be more important for adult immigrants aged 23 and above. Since those immigrants are more likely to be in the control group, we possibly underestimate the returns to German citizenship. To check whether this could explain the absence of returns for male immigrants, we drop all immigrants who report having a German spouse in 2007-2009. ${ }^{31}$ The results reported in Table 9 show a very similar pattern than before: no returns to citizenship for male immigrants once we control for years in Germany and positive returns for female immigrants across all specifications.

A third concern is that the 2000 reform not only changed the residency requirement for adult immigrants but also granted citizenship to children born in Germany to foreign-born parents. Immigrants with dependent children had therefore a higher incentive to naturalize prior to 2000 because they could include spouses and dependent children in their application. After 2000, newborn children obtained German citizenship independently of their parents (except for a 8 year residency requirement for at least one parent). Hence, the benefits of citizenship might be smaller after 2000 for parents with very young children. Controlling for the presence of children in the household as well as their age structure does not change our results.

Fourth, our sample of naturalized citizens could also be affected by changes in the inflow of refugees and asylum seekers. Prior to 1988, Germany had relatively low inflows of asylum seekers (about 60-70,000 per year). After the opening of the Iron Curtain, large numbers of asylum seekers (more than 200,000 per year) began to arrive in Germany. Faced with ever-increasing numbers, the federal government restricted access to political asylum in $1993 .^{32}$ Hence, the selection of refugees arriving in Germany might have changed substantially over time, especially after 1993. Refugees who

\footnotetext{
${ }^{30}$ The immigrant has to be married for at least two years by the time he or she applies for naturalization; furthermore, the spouse has to have a German citizenship for at least 2 years. Finally, the couple has to have a permanent residence permit.

${ }^{31}$ Note that we only observe their current spouse, not the spouse or partner an immigrant had when they first lived in Germany. Some immigrants we drop from the sample might have naturalized through the provisions of the 1990 or 2000 reforms but married a German citizen only afterward. And some immigrants might have naturalized through a German spouse, but got divorced before we observe them in the 2007-2009 sample period. We think that the number of immigrants we misclassify should be small relative to the number of immigrants who still have a German spouse in the 2007-2009 period. We find similar results if we use the SOEP where we have annual information on the immigrant's partner from 1984-2009 (results are available upon request).

${ }^{32}$ After 1993, immigrants from source countries that are considered safe, or those arriving from safe third countries (which included all of Germany's geographic neighbors) could no longer apply for political asylum in Germany.
} 
are granted political asylum face the same naturalization criteria as all other immigrants in Germany. In some cases, however, the residency requirement could be reduced to 6 years. As such, some refugees might have naturalized earlier than our definition of eligibility indicates. Unfortunately, we do not directly observe whether an immigrant arrives in Germany as a refugee or asylum seeker. Yet, we can run two additional tests to check whether our results hold for the subsample of nonrefugees: first, we drop all immigrants from ex-Yugoslavia and the Middle East which formed the largest groups of refugees over our sample period. Our second test restricts the sample to immigrants arriving in Germany prior to 1988 when numbers of refugees were still small. Table 8 shows that immigrant samples net of refugees show the same wage patterns than the main results.

Fifth, changes in the German economy more broadly might have an influence on the results. Germany's labor market experienced a substantial inflow of migrants after the fall of the Berlin Wall and the opening of the Iron Curtain. In addition, wage inequality in Germany increased in the late 1990s and 2000s with substantial net gains for the high-skilled but net wage losses for the low-skilled. In principle, these changes would be absorbed by year dummies or state trends if changes vary across German states. Our reduced-form estimates would only be biased if business cycle effects or secular wage changes affect recently eligible immigrants differently than not yet eligible immigrants. If eligible immigrants perform better during a recession than non-eligible immigrants, for instance, our results would be upward biased. Our first robustness test drops all East German states because immigration flows and labor market dynamics differ substantially between East and West Germany. Alternatively, we include state-level unemployment rates and GDP growth rates to our specification. In both cases, results are very similar to our main estimates.

Sixth, our results might be sensitive to functional form assumptions. Recall that the reducedform effect is identified from variation in the eligibility variable net of a quadratic in age and years in Germany. To allow for more flexible age and assimilation effects, we include separate indicators for 5-year age groups; we then add separate indicators for 5-years arrival cohorts as well. The last two specifications in Table 9 shows that our results are robust to these alternative definitions of the main control variables: access to citizenship still carries no wage return for men and sizable wage returns for immigrant women. ${ }^{33}$

\footnotetext{
${ }^{33}$ A related concern is that our immigrant sample might suffer from cohort bias where more recent arrival cohorts are of higher (or lower) quality in terms of observable characteristics than older arrival cohorts. As our estimates rely on cross-sectional variation between different immigrant cohorts (defined by age, arrival year and time period), cohort bias could in principle affect our results, though the direction of the bias is not so clear. Using Microcensus data from 2000 to 2009, we check whether earnings of more recent arrival cohorts are below or above those of earlier arrival cohorts (holding years in Germany and age effects constant). We find little evidence for cohort bias in the German context (the results are available upon request) which suggests that our results are indeed driven by a more
} 
Seventh, we probe the validity of our identifying assumption using pre-reform data from the SOEP. Table A8 compares the characteristics of immigrants who get eligible shortly after the 1991 reform to those who get eligible later (in the 1996-1999 period). Each entry reports the coefficient from a regression on an indicator equal to one if an immigrant is eligible in 1991-1995 and zero if she gets eligible in 1996-1999. All regressions control for age, age squared, years in Germany (a linear and squared term), region of origin, year and state fixed effects as well as state-specific linear trends. The results show few statistically significant differences between immigrants in the pre-reform period (1984-1989). The only exception for men is that immigrants who get eligible in the first years after the 1991 reform are more likely to be employed in the service sector (and hence, less likely to be employed in manufacturing). Among women, immigrants eligible shortly after the reform live in somewhat smaller households and are somewhat less likely to work full time. All differences are just borderline significant at the $10 \%$ level.

An alternative way to test the validity of our identifying assumption is to use placebo reforms. To check for differential pre-reform trends, we use the same eligibility rules as in the actual reforms but pretend that the reform took place $2,3,4$, or 5 years before 1991 . We restrict attention to the first reform because immigrants in the pre-2000 years would be affected by the 1991 reform. Table A9 in the appendix shows no prior trends for male and female wages and also no prior trend for female employment. The only exception is that labor force participation among male immigrants shows a positive trend 5-6 years prior to the 1991 reform, but not in the period shortly before the actual reform. Since we find no effect of the citizenship reform on employment, we think this is not a major issue.

Finally, our main analysis only identifies whether naturalization or eligibility for citizenship has a persistent effect on the growth rate of wages. Because we only observe immigrants in the Microcensus several years after they actually naturalize or become eligible for citizenship, we cannot identify any level effect of citizenship on labor market outcomes. However, citizenship might shift employment or wages immediately after naturalization, for example if immigrants switch careers immediately. To test for level effects in employment and wages, we again use the SOEP where we can identify both an immediate wage effect of naturalization or eligibility (a level effect) and any persistent effect on wage growth because of faster human capital accumulation (a slope effect). We capture the level effect by a dummy variable whether an individual is naturalized or eligible in the current year. As before, we identify the slope effect by including a measure of years since naturalization or eligibility liberal access to citizenship and not by changes in immigrant selection. 
for citizenship. The results in Table A10 in the appendix show that level effects do not matter once we condition on time in Germany. Overall, the results are consistent with the evidence in Table 2 and 3. There are no growth effects of citizenship for men but positive growth effects for women. ${ }^{34}$

\section{Conclusion}

We study the effects of citizenship in Germany, a country that has traditionally had little experience with naturalizations. Over the past decades Germany has moved from a country where citizenship was closely tied to ancestry to a more liberal understanding of citizenship and naturalization. We find that the take-up of citizenship in Germany among first-generation immigrants is still low compared to more traditional immigration countries, though higher among more recent immigrants. In contrast to traditional immigrant countries, we do not find positive selection into German citizenship. Men are intermediately selected in terms of observable skills, as medium-skilled immigrants are more likely to naturalize than the low-skilled, but also more likely than high-skilled immigrants. Women, in contrast, are even negatively selected with respect to education, with high-skilled immigrants being less likely to naturalize than low- and medium-skilled immigrants. We also find that younger immigrants are more likely to naturalize in Germany.

To identify the effects of citizenship acquisition in the labor market, we exploit age-dependent residency requirements in Germany's reforms of citizenship law. Our intention-to-treat effect shows few permanent benefits of citizenship for men, but substantial returns for immigrant women. Our calculations show that for immigrant women, access to citizenship accounts for $70 \%$ of the overall assimilation rate in Germany. ${ }^{35}$

In contrast to previous evidence from the US, we do not find evidence that immigrants work more in the public sector or in a white-collar job after citizenship. We also find no support that the wage returns are driven by improvements in German language skills. Rather, a more liberal access to citizenship allows women to move to jobs with a permanent contract, to larger firms and to better-paying occupations in the private sector. About $30 \%$ of the wage returns are driven by moving to higher paying occupations and industries. Exploring the heterogeneity of returns, we find

\footnotetext{
${ }^{34}$ The main difference to our main results (using the Microcensus) is that for men even the OLS estimates show no correlation between naturalization and labor market outcomes. This result is most likely the consequence of measurement error; in the SOEP, we have no direct information on the year of naturalization but have to infer naturalizations from changes in citizenship status reported in each year.

${ }^{35} \mathrm{~A}$ regression of personal income on all control variables and years in Germany (linear and ssquared terms) yields an annual assimilation rate of $2 \%$ in our sample. The wage return for citizenship was $1.4 \%$ for immigrant women (see Table 3, column (9)). Hence, $1.4 / 2.0=0.7$.
} 
that wage returns are typically larger for immigrants from outside the European Union and, more generally, for immigrants from poorer countries. The picture is also more optimistic if we focus on more recent immigrant men and women which enjoy substantial wage returns to citizenship. Overall then, naturalization appears to be one channel to improve the economic integration of immigrants even in countries where access to citizenship has traditionally been very restrictive. The benefits of a more liberal immigration policy seem to materialize especially if immigrants have the human capital necessary to succeed in the host country's labor market - a condition more recent immigrants to Germany are more likely to satisfy. As such, the substantial inflow of immigration over the past decades is likely to large fiscal and labor market benefits for Germany. Yet, our results also show that access to citizenship is not a tool that works for every immigrant arriving in Germany.

\section{References}

[1] Abramitzky, R., L.P. Boustan and K. Eriksson (2012), "Europe's tired, poor, huddled masses: Selfselection and economic outcomes in the age of mass migration," American Economic Review, 102, 183256.

[2] Aleksynska, M. and Y. Algan (2010), "Assimilation and integration of immigrants in Europe," IZA Discussion Paper No. 5185.

[3] Algan, Y., C. Dustmann, A. Glitz and A. Manning (2010), "The economic situation of first- and secondgeneration immigrants in France, Germany, and the UK," Economic Journal, 120, F4-F30.

[4] Avitabile, C., I. Clots-Figueras and P. Masella (2013a), "The effect of birthright citizenship on parental integration outcomes," Journal of Law and Economics, 56, 777-810.

[5] Avitabile, C., I. Clots-Figueras and P. Masella (2013b), "Citizenship, fertility and parental investments," American Economic Journal: Applied Economics, forthcoming.

[6] Basilio, L. and T. Bauer (2010), "Transferability of human capital and immigrant assimilation: An analysis for Germany," IZA Discussion Paper No. 4716.

[7] Bauer, T., B. Dietz, K.F. Zimmermann and E. Zwintz (2005), "German migration: Development, assimilation, and labor market effects". In: European Migration. What do we know?, edited by K.F. Zimmermann, pp. 197-261. Oxford: Oxford University Press.

[8] Bevelander, P. and R. Pendakur (2011), "Citizenship, co-ethnic populations, and employment probabilities of immigrants in Sweden," Journal of International Migration and Integration, 13, $203-222$.

[9] Bevelander, P. and J. Veenman (2008). "Naturalisation and socioeconomic integration: The case of the Netherlands." In: The economics of citizenship, edited by P. Bevelander and D.J. DeVoretz. Malmö: Holmbergs.

[10] Birkner, E. (2007), "Aussiedler im Mikrozensus: Identifizierungsprobleme und erste Analysen zur Arbeitsmarktintegration," Presentation at the Workshop „Integrationschancen von Stätaussiedlern,“ March 29-30, Institute for Employment Research (IAB), Nuremburg.

[11] Borjas, G. (1985), "Assimilation, changes in cohort quality, and the earnings of immigrants," Journal of Labor Economics, 3, 463-89.

[12] Borjas, G. (2013), "The slowdown in the economic assimilation of immigrants: Aging and cohort effects revisited again," NBER working paper No. 19116. 
[13] Borjas, G. and L. Hilton (1996), "Immigration and the welfare state: Immigrant participation in meanstested entitlement programs," Quarterly Journal of Economics, 111, 575-604.

[14] Bratsberg, B., Ragan, J. F. and Z. M. Nasir (2002). "The effect of naturalization on wage growth: A panel study of young male immigrants." Journal of Labor Economics, 20, 568-97.

[15] Bratsberg, B. and O. Raaum (2011), "The labour market outcomes of naturalised citizens in Norway," In: Naturalisation: A passport for the better integration of immigrants?, edited by the Organisation for Economic Cooperation and Development (OECD), Paris: OECD.

[16] Bundesministerium des Inneren (2008), Migrationsbericht des Bundesamtes für Migration und Flüchtlinge im Namen der Bundesregierung, Berlin: Federal Ministry of the Interior.

[17] Bundesamt für Migration und Flüchtlinge (BAMF) (2008), "Die Einbürgerung von Ausländern in Deutschland", Federal Office for Migration and Refugees, Working Paper No. 17.

[18] Bundesamt für Migration und Flüchtlinge (BAMF) (2012), "Einbürgerungsverhalten von Ausländerinnen und Ausländern in Deutschland sowie Erkenntnisse zu Optionspflichtigen", Federal Office for Migration and Refugees, Research Paper No. 15.

[19] Card, D. (2005), "Is the new immigration really so bad?" Economic Journal, 115, F300-F323.

[20] Chiswick, B. R. (1978), "The effect of Americanization on the earnings of foreign-born men." Journal of Political Economy, 86, 897-921.

[21] Chiswick, B. R. and P. W. Miller (1995), "The endogeneity between language and earnings: International analyses." Journal of Labor Economics, 13 (2), 246-88.

[22] Chiswick, B. R. and P.W. Miller (2008), "Citizenship in the US: The roles of immigrant characteristics and country of origin," Research in Labor Economics, 29, 91-130.

[23] Clark, K. and J. Lindley (2009), "Immigrant assimilation pre and post labour market entry: evidence from the UK Labour Force Survey," Journal of Population Economics, 22, 175-198.

[24] Constant, A.F., Gataullina, L. and K. F. Zimmermann (2009). "Naturalization proclivities, ethnicity and integration," International Journal of Manpower, 30, 70-82.

[25] Constant, A.F. and D. Massey (2002), "Self-Selection, earnings, and out-migration: A longitudinal study of immigrants in Germany," IZA Discussion Paper No. 672.

[26] De Voretz, D. and S. Pivnenko (2006), "The economic causes and consequences of Canadian citizenship," Journal of Immigration and Integration, 6, 435-68.

[27] Duleep, H.O. and D. J. Dowhan (2002), "Insights from longitudinal data on the earnings growth of U.S. foreign-born men," Demography, 39, 485-506.

[28] Dustmann, C. (1993), "Earnings Adjustment of Temporary Migrants," Journal of Population Economics, $6,153-168$.

[29] Dustmann, C. (1994), "Speaking fluency, writing fluency and earnings of migrants," Journal of Population Economics, 7, 133-156.

[30] Dustmann, C. and A. Glitz (2011), "Migration and Education," Handbook of Economics of Education, edited by E. Hanushek, North Holland: Elsevier, vol. 4, pp. 327-439.

[31] Dustmann, C. and A. Van Soest (2001), "Language fluency and earnings estimation with misclassified language indicators," Review of Economics and Statistics, 83, 663-674.

[32] Fertig, M. and S. Schurer (2007), "Earnings assimilation of immigrants in Germany: The importance of heterogeneity and attrition bias," DIW Discussion Paper No. 30.

[33] Fougère, D., Safi, M. (2009). "The effects of naturalization on immigrants employment probability (France, 1968-1999)," International Journal of Manpower, 30, 83-96.

[34] Hailbronner, K. and G. Renner (1992), Staatsangehörigkeitsrecht, Texte, Munich: C. H. Beck. 
[35] Hanson, G.H. (2009), "The economic consequences of the international migration of labor," Annual Review of Economics, 1, 179-207.

[36] Heston, A., R. Summers and B. Aten (2011), "Penn World Table Version 7.0," Center for International Comparisons of Production, Income and Prices at the University of Pennsylvania.

[37] Howard, M. M. (2008), "The causes and consequences of Germany's new citizenship law," German Politics, 17, 41-62.

[38] Hu, W.-Y. (2000), "Immigrant earnings assimilation: Estimates from longitudinal data," American Economic Review P\&P, 90, 368-72.

[39] Kaas, L. and C. Manger (2012), "Ethnic discrimination in Germany's labour market: A field experiment," German Economic Review, 13, 1-20.

[40] Lalonde, R. and R. Topel (1997), "Economic impact of international migration and the economic performance of migrants." In: Handbook of Population and Family Economics, vol. 1B, edited by Mark R. Rosenzweig and Oded Stark. Amsterdam: Elsevier Science.

[41] Licht, G. and V. Steiner (1994), "Assimilation, labour market experience, and earning profiles of temporary and permanent immigrant workers in Germany," International Review of Applied Economics, 8, $130-56$.

[42] Lubotsky, (2007), "Chutes or ladders? A longitudinal analysis of immigrant earnings," Journal of Political Economy, 115, 820-67.

[43] Mazzolari, F. (2009), "Determinants and effects of naturalization: the role of dual citizenship laws", Demography, 46, 169-91.

[44] Organisation for Economic Cooperation and Development (2006), International Migration Outlook: SOPEMI-2006 Edition, Paris: OECD

[45] Organisation for Economic Cooperation and Development (2011), Naturalisation: A passport for the better integration of immigrants? Paris: OECD.

[46] Pischke, J.-S. (1993), "Assimilation and the earnings of guestworkers in Germany," unpublished manuscript, MIT.

[47] Schmidt, C.M. (1997), "Immigrant performance in Germany: Labor earnings of ethnic German migrants and foreign guest workers," Quarterly Review of Economics and Finance, 37, 379-97.

[48] Scott, K. (2008), "The economics of citizenship: Is there a naturalization effect?" In: The economics of citizenship, edited by P. Bevelander and D.J. DeVoretz. Malmö: Holmbergs.

[49] Socio-Economic Panel (SOEP) (2010), data for years 1984-2009, version 26, doi:10.5684/soep.v26.

[50] Steinhardt, M.F. (2012), "Does citizenship matter? The economic impact of naturalizations in Germany", Labour Economics, 19, 813-23.

[51] Steinhardt, M. F. and J. Wedemeier (2012), "The labor market performance of naturalized immigrants in Switzerland - New evidence from the Swiss Labor Force Survey," Journal of International Migration and Integration, 13, 223-242.

[52] Wagner, G., Frick, J. R. and J. Schupp (2007), "The German Socio-Economic Panel Study (SOEP) Scope, evolution and enhancements." Schmollers Jahrbuch, 127 (1): 139-169.

[53] Yang, P.Q. (1994), "Explaining immigrant naturalization," International Migration Review, 28, 3: 44977. 


\section{A German Microcensus (2007-2009)}

Data and Sample: The Microcensus interviews about 830,000 individuals each year. Participation is required by law (though answering some questions is voluntary) as the data form the basis for the calculation of nationally representative labor market statistics. The scientific use file is a $70 \%$ subsample of the official dataset. We restrict the sample to first-generation immigrants, i.e. foreign-born individuals who live in private households in Germany. For each person, we know the year the person arrived in Germany and the country of origin. Individuals born abroad to German parents are also contained in the foreign-born sample but can be identified as their country of origin is missing. We further restrict our sample to immigrants who arrived in Germany between 1976 and 2000 and are between 16 and 35 years of age in the post-reform period (1991-2009).

Since 2005, the survey records whether and how an immigrant has obtained German citizenship and the year in which naturalization took place. To define our sample of interest, we first calculate the number of years an immigrant has lived in Germany. Together with the age of an individual in the post-reform period, we then define the year an immigrant is first eligible for citizenship based on the residency requirement. An immigrant arriving in 1976 becomes eligible for citizenship in 1991 independent of her age. Adolescent immigrants (aged 16-22) arriving between 1977 and 1982 become eligible in 1991 while those arriving between 1983 and 2000 become eligible after 8 years (between 1991 and 2009). Adult immigrants (aged 23 and older) arriving between 1977 and 1985 become eligible after 15 years of residence (between 1991 and 2000). Adult immigrants arriving between 1986 and 1991 all become eligible in 2000 when the reduced residency requirement comes into effect. All adult immigrants arriving between 1992 and 2000 become eligible after 8 years of residency (between 2000 and 2009). In the final step, we then calculate the number of years an immigrant in 2007-2009 has been eligible for German citizenship.

We also need to distinguish regular immigrants from ethnic Germans ("Aussiedler") who are not affected by the 1991 and 2000 reforms. Ethnic Germans have some German ancestry and have access to German citizenship within three years of arrival. Aggregate statistics suggest that migration flows of ethnic Germans started in 1985 with less than 50,000 per year, peaked between 1988 and 1991 at around 300,000 per year, remained at about 200,000 per year between 1992 and 1996 and then subsided to 100,000 and below after 1998 (Bundesministerium des Inneren, 2009). We first define ethnic Germans as individuals born outside Germany with a German passport who naturalized within three years of arrival in Germany (which is legally impossible for regular immigrants) and whose previous nationality was Czech, Hungarian, Kazakh, Polish, Romanian, Russian, Slovakian or Ukrainian as ethnic Germans (see Birkner, 2007: Algan et al., 2010 follow the same approach). Based on this definition, we identify and exclude about 58,000 ethnic Germans in our data over the period from 2005 to 2009. After applying this restriction, our data still contain immigrants from Eastern Europe or the Former Soviet Union who naturalize much earlier than the required 8 or 15 years. We therefore restrict our sample to the 2007-2009 survey years when we explicitly know whether an immigrant naturalized as an ethnic German or not.

Dependent variables: Our primary outcome variable is the log of monthly net personal income. The variable combines labor earnings, income from self-employment, rental income, public and private pensions as well as public transfers (like welfare or unemployment benefits, child benefit or housing subsidies) but is net of taxes and other contributions. To deflate income to constant Euros, we use the consumer price index from the Federal Statistical Office (the base year is 2005). The income variable is recorded as a categorical variable with 24 categories. We use the midpoint of each category to convert personal income into a continuous variable.

Our second outcome variable is employment. The question about employment asks whether an individual has been working for pay or has been engaged in an income generating activity in the previous week ("Haben Sie in der vergangenen Woche eine bezahlte bzw. eine mit einem Einkommen verbundene Tätigkeit ausgeübt? Dabei ist es egal, welchen zeitlichen Umfang diese hatte."). We define a person as employed if she works fulltime or part-time, works for less than 400 Euros per month, works in a family business or works in a job temporarily. A person is not employed in the current year if she is either unemployed, on long-term parental leave (longer than three months) or out of the labor force. Alternatively, we define individuals as employed if they are unemployed but available for work. We also analyze whether naturalized immigrants are more likely to work in the public sector or in a white-collar job. A white-collar job is defined as working as a clerk or officer, judge or civil servant. The variable is zero if someone is employed as a worker or home worker. 
Here, we exclude trainees ("Auszubildende") and family workers.

Our third outcome of interest is economic self-sufficiency. The variable is coded as one if an individual receives welfare benefits, either unemployment benefits ("Arbeitslosengeld I") or social assistance ("Arbeitslosengeld II'); and zero otherwise. Finally, we study whether an individual works on a temporary or permanent contract.

Control variables: Educational attainment is defined as low-skilled if the individual has no vocational degree and at most a lower secondary school degree. A migrant is medium-skilled if she has a vocational degree or high school degree; and she is high-skilled if she has a college degree. The occupation variable distinguishes between self-employed, civil servant, employee, workers, trainees and soldiers while the sector variable distinguishes between 8 broad sectors.

To explore the heterogeneity of naturalization effects, we study immigrants from different countries of origin. In particular, we define ten categories of countries of origin based on the current citizenship (for those who do not naturalize) or the citizenship prior to naturalization (for those naturalized). The first group (EU15: Austria, Belgium, Denmark, Finland, France, Greece, Ireland, Italy, Luxembourg, Netherlands, Portugal, Spain, Sweden and United Kingdom) includes all countries from the European Union before the enlargement of 2004 as well as Switzerland and Norway. This group had already free access to the German labor market in the 1990s. The second group consists of immigrants from Eastern European countries which joined the EU in 2004 but did not have full access to the labor market prior to 2011 (EU12: Bulgaria, Czech Republic, Estonia, Hungary, Latvia, Lithuania, Poland, Romania, Slovakia, Slovenia as well as Malta and Cyprus). The other important source countries are former Yugoslavia except Slovenia (Bosnia and Herzegovina, Croatia, Kosovo, Macedonia, Montenegro, Serbia) and Turkey. We lump together other immigrants into broad regions: the Middle East (for example Afghanistan, Iran and Iraq), Africa (for example Morocco), Asia (for example China and Vietnam), North and South America as well as Russia and other former Soviet republics which are not member of the European Union. The last category contains immigrants who either have no exact region of origin ("other European country" or "rest of the world") or report not having any citizenship at all.

To test whether immigrants from lower-income countries benefit more from naturalization, we use the GDP per capita in the country of origin (divided by 1,000) in 2005 from the Penn World Tables (Heston et al., 2011). The sample including the GDP data is smaller as we can only match immigrants where we know the actual country of origin and not only the broad region (such as North Africa). To control for state-specic labor market shocks, we use the state unemployment rate defined as percentage of registered unemployed people to the total number of employed persons. To control for the state's economic situation more broadly, we use the growth rate in state GDP per capita from the national accounts data.

\section{B Socio-Economic Panel (1984-2009)}

Data and Sample: The Socio-Economic Panel (SOEP) is a household survey that has been conducted annually since 1984 (in East Germany since 1990). The original sample oversampled migrants from traditional sending countries (like Turkey, Yugoslavia or Italy). Several refreshment samples including another immigrant sample have been drawn in subsequent years to maintain the representativeness of the SOEP. Interviews are performed in German, the respondent's native language or a mixed mode. Our basic sample consists of all foreigners living in private households who were born abroad and migrated to Germany between 1976 and 2000 ("first-generation immigrants").

The survey asks respondents whether they are German citizens; if they answer no, the respondent is asked about his or her current nationality. We can then identify naturalizations if the first-generation immigrant reports a German citizenship in the current year and a foreign citizenship in previous years. Note that this definition only captures individuals that naturalize while in the SOEP sample. It does not record naturalizations that occur prior to or after being a SOEP participant which introduces two potential sources of bias: first, a sample member might drop out of the SOEP and naturalize after leaving the sample. If an immigrant instead naturalizes before she enters the panel, we only observe that a first-generation immigrant is naturalized but not in which year. In the main analysis, we restrict our sample to firstgeneration immigrants who naturalize while being a sample member in the SOEP. To the extent that this sample is representative of immigrants more broadly, this should not affect our results. Alternatively, we 
assign the first observation in the panel as the year of naturalization; this would understate the first-stage effect of eligibility (which is measured independently from sample membership) and would also understate the returns of naturalization (because naturalization is defined later than it actually occurred). In both cases, our coefficients are conservative estimates of the true effect. In 2002, the survey asks all naturalized immigrants in which year they obtained their German citizenship. We use this information together with additional consistency check to reduce measurement error in the naturalization variable. To distinguish first-generation immigrants from ethnic Germans, we use the same procedure as in the Microcensus (following Birkner, 2007).

We further restrict the sample to first-generation immigrants between age 16 and 35 in the 1991-2009 period. Based on the residency requirement, the eligibility indicator is equal to one if (1) an individual has been in Germany for at least 8 years and is betweeen 16 and 22 years old in the post-1990 period; (2) if an immigrant has been in Germany for at least 15 years and is 23 years old or above during the survey years 1991-1999; and (3) if an immigrant has been in Germany for at least 8 years and is 23 years-old or above in the survey years 2000-2009. The indicator is zero if a first-generation immigrant is not (yet) eligible for naturalization in the current year.

Dependent variables: The main dependent variable is self-reported language skills which are asked roughly every second year (1984-1987, 1989, 1991, 1993, 1995. 1997, 1999, 2001, 2003, 2005, 2007 and 2009). We recode the language variables which are asked separately for writing and speaking German such that the highest value (4) corresponds to very good language skills while the lowest value (0) implies that the immigrant has no German language skills. Earnings are measured as the log of monthly gross labor earnings deflated to 2006 prices using the national consumer price index. Employment is equal to one if an immigrant works in any type of employment and zero if a person is unemployed or out of the labor force. Firm size is a categorical variable ranging from 1 (self-employed without employees or working in a company with less than 5 employees) to 10 (firm with 2000 or more employees).

Control variables: Educational attainment is defined as in the Microcensus: low-skilled if an immigrant has no vocational degree and at most a lower secondary school degree; medium-skilled if she has a vocational degree or high school degree ("Abitur") and high-skilled if she has a college degree. We use the same classification as in the Microcensus to classify source countries into 10 broad groups of origin. 
Table 1: The Propensity to Naturalize after the 1991 and 2000 Reforms

\begin{tabular}{|c|c|c|c|c|c|c|}
\hline & \multicolumn{3}{|c|}{ Male Immigrants } & \multicolumn{3}{|c|}{ Female Immigrants } \\
\hline & $\begin{array}{c}\text { Base } \\
(1) \\
\end{array}$ & $\begin{array}{c}\text { Years in G } \\
(2)\end{array}$ & $\begin{array}{c}\text { Origin } \\
(3) \\
\end{array}$ & $\begin{array}{c}\text { Base } \\
(4) \\
\end{array}$ & $\begin{array}{c}\text { Years in G } \\
(5)\end{array}$ & $\begin{array}{c}\text { Origin } \\
(6) \\
\end{array}$ \\
\hline Eligible for Naturalization & $\begin{array}{c}0.057^{* * *} \\
{[0.010]}\end{array}$ & $\begin{array}{c}0.041^{* *} \\
{[0.017]}\end{array}$ & $\begin{array}{c}-0.062 * * * \\
{[0.014]}\end{array}$ & $\begin{array}{c}0.131^{* * *} \\
{[0.010]}\end{array}$ & $\begin{array}{c}0.049 * * * \\
{[0.010]}\end{array}$ & $\begin{array}{c}-0.092 * * * \\
{[0.016]}\end{array}$ \\
\hline Eligible*new EU12 & & & $\begin{array}{c}0.062^{* *} \\
{[0.029]}\end{array}$ & & & $\begin{array}{c}0.235^{* * *} \\
{[0.030]}\end{array}$ \\
\hline Eligible*Ex-Yugoslavia & & & $\begin{array}{c}0.064^{* * *} \\
{[0.019]}\end{array}$ & & & $\begin{array}{c}0.061^{* * *} \\
{[0.018]}\end{array}$ \\
\hline Eligible*Turkey & & & $\begin{array}{c}0.103^{* * *} \\
{[0.013]}\end{array}$ & & & $\begin{array}{c}0.118^{* * *} \\
{[0.012]}\end{array}$ \\
\hline Eligible*Middle East & & & $\begin{array}{c}0.456 * * * \\
{[0.074]}\end{array}$ & & & $\begin{array}{c}0.541 * * * \\
{[0.088]}\end{array}$ \\
\hline Eligible*Africa & & & $\begin{array}{c}0.348 * * * \\
{[0.094]}\end{array}$ & & & $\begin{array}{c}0.183^{* *} \\
{[0.078]}\end{array}$ \\
\hline Eligible*Asia & & & $\begin{array}{c}0.265^{* * *} \\
{[0.072]}\end{array}$ & & & $\begin{array}{c}0.485^{* * *} \\
{[0.053]}\end{array}$ \\
\hline Eligible*(North and South America) & & & $\begin{array}{c}0.178^{* *} \\
{[0.071]}\end{array}$ & & & $\begin{array}{c}0.221 * * * \\
{[0.066]}\end{array}$ \\
\hline Eligible*(Russia and Former SU) & & & $\begin{array}{c}0.044^{* *} \\
{[0.021]}\end{array}$ & & & $\begin{array}{c}0.142^{* * *} \\
{[0.025]}\end{array}$ \\
\hline Eligible*(Other or No Citizenship) & & & $\begin{array}{c}0.039 \\
{[0.029]}\end{array}$ & & & $\begin{array}{c}-0.016 \\
{[0.168]}\end{array}$ \\
\hline Years in Germany & & $\begin{array}{l}-0.001 \\
{[0.004]}\end{array}$ & $\begin{array}{l}-0.001 \\
{[0.004]}\end{array}$ & & $\begin{array}{c}0.010 * * * \\
{[0.002]}\end{array}$ & $\begin{array}{c}0.009 * * * \\
{[0.002]}\end{array}$ \\
\hline Years in Germany Squared & & $\begin{array}{c}0.000 \\
{[0.000]}\end{array}$ & $\begin{array}{c}0.000 \\
{[0.000]}\end{array}$ & & $\begin{array}{c}0.000 \\
{[0.000]}\end{array}$ & $\begin{array}{c}0.000 \\
{[0.000]}\end{array}$ \\
\hline Age & $\begin{array}{c}-0.000 \\
{[0.003]}\end{array}$ & $\begin{array}{l}-0.000 \\
{[0.003]}\end{array}$ & $\begin{array}{l}-0.001 \\
{[0.003]}\end{array}$ & $\begin{array}{c}-0.008 * * * \\
{[0.003]}\end{array}$ & $\begin{array}{c}-0.011 * * * \\
{[0.003]}\end{array}$ & $\begin{array}{c}-0.011^{* * *} \\
{[0.003]}\end{array}$ \\
\hline Age Squared & $\begin{array}{c}0.000 \\
{[0.000]}\end{array}$ & $\begin{array}{c}0.000 \\
{[0.000]}\end{array}$ & $\begin{array}{c}0.000 \\
{[0.000]}\end{array}$ & $\begin{array}{c}0.000 * * * \\
{[0.000]}\end{array}$ & $\begin{array}{c}0.000 * * * \\
{[0.000]}\end{array}$ & $\begin{array}{c}0.000^{* * *} * \\
{[0.000]}\end{array}$ \\
\hline Medium-skilled & $\begin{array}{c}0.036 * * * \\
{[0.006]}\end{array}$ & $\begin{array}{c}0.036 * * * \\
{[0.006]}\end{array}$ & $\begin{array}{c}0.035^{* * *} \\
{[0.006]}\end{array}$ & $\begin{array}{c}0.036 * * * \\
{[0.007]}\end{array}$ & $\begin{array}{c}0.036 * * * \\
{[0.007]}\end{array}$ & $\begin{array}{c}0.037^{* * *} \\
{[0.007]}\end{array}$ \\
\hline High-skilled & $\begin{array}{c}0.010 \\
{[0.014]}\end{array}$ & $\begin{array}{c}0.019 \\
{[0.014]}\end{array}$ & $\begin{array}{l}0.026 * \\
{[0.013]}\end{array}$ & $\begin{array}{c}-0.058 * * * \\
{[0.015]}\end{array}$ & $\begin{array}{c}-0.042 * * * \\
{[0.014]}\end{array}$ & $\begin{array}{c}-0.047^{* * *} \\
{[0.014]}\end{array}$ \\
\hline In School & $\begin{array}{c}0.051 * * * \\
{[0.011]}\end{array}$ & $\begin{array}{c}0.048 * * * \\
{[0.011]}\end{array}$ & $\begin{array}{c}0.047^{* * *} \\
{[0.011]}\end{array}$ & $\begin{array}{c}0.067^{* * *} \\
{[0.012]}\end{array}$ & $\begin{array}{c}0.054 * * * \\
{[0.012]}\end{array}$ & $\begin{array}{c}0.052 * * * \\
{[0.012]}\end{array}$ \\
\hline Region of Origin Fixed Effects & Yes & Yes & Yes & Yes & Yes & Yes \\
\hline Year Fixed Effects & Yes & Yes & Yes & Yes & Yes & Yes \\
\hline State Fixed Effects & Yes & Yes & Yes & Yes & Yes & Yes \\
\hline State-specific Linear Trends & Yes & Yes & Yes & Yes & Yes & Yes \\
\hline Observations & 9,642 & 9,642 & 9,642 & 10,223 & 10,601 & 10,601 \\
\hline R Squared & 0.683 & 0.686 & 0.690 & 0.625 & 0.632 & 0.640 \\
\hline Mean of Dependent Variable & 0.107 & 0.107 & 0.107 & 0.086 & 0.086 & 0.086 \\
\hline
\end{tabular}

Notes: The dependent variable is a binary indicator equal to one if a first-generation migrant has naturalized and zero otherwise. The sample includes all migrants who are not ethnic Germans, arrived in Germany between 1976 to 2000, are 16 to 35 years-old in the post-policy period (1991-2009), and report valid information on income, naturalization and years lived in Germany. The eligibility indicator is equal to one if an individual is either: a) $16-22$ years old and has lived in Germany for at least 8 years after 1991; b) is 23-35 years old and has lived in Germany for at least 15 years in the $1991-1999$ period; or c) is 23-35 years old and has lived in Germany for at least 8 years in the 2000-2009 period. The left-hand side reports results from a linear probability model for men, the right-hand side for women. All specifications include state and year fixed effects as well as state-specific linear trends. All specifications also control for 10 region of origin fixed effects (traditional EU countries, new EU entrants (EU-12), ex-Yugoslavia, Turkey, Middle East, Asia, Africa, North and South America, Russia and other former Soviet Union republics, other or no citizenship). The second specification (columns (2) and (5)) add a linear and squared term of years in Germany. The third specification (columns (3) and (6)) allows for heterogeneous effects of eligibility by region of origin. The omitted region of origin is EU-15 member states; the omitted education category is low-skilled (without high school or vocational degree). Standard errors in brackets are clustered at the age $x$ arrival cohort level. Statistical significance: ${ }^{* * *} p<0.01, * * p<0.05, * p<0.1$.

Source : Socio-Economic Panel (1984-2009) 
Table 2: OLS Estimates of Naturalization and Labor Market Outcomes

\begin{tabular}{|c|c|c|c|c|c|c|c|c|c|c|}
\hline & \multicolumn{5}{|c|}{ Male Immigrants } & \multicolumn{5}{|c|}{ Female Immigrants } \\
\hline & \multicolumn{2}{|c|}{ Employment } & \multicolumn{3}{|c|}{ Log Personal Income } & \multicolumn{2}{|c|}{ Employment } & \multicolumn{3}{|c|}{$\underline{\text { Log Personal Income }}$} \\
\hline & (1) & (2) & (3) & (4) & (5) & (6) & (7) & (8) & (9) & (10) \\
\hline Years since Naturalized & $\begin{array}{c}0.004^{* * *} \\
{[0.001]}\end{array}$ & $\begin{array}{c}0.003^{* * *} \\
{[0.001]}\end{array}$ & $\begin{array}{c}0.007^{* * *} \\
{[0.001]}\end{array}$ & $\begin{array}{c}0.005^{* * *} \\
{[0.001]}\end{array}$ & $\begin{array}{c}0.002^{* *} \\
{[0.001]}\end{array}$ & $\begin{array}{c}0.006^{* * *} \\
{[0.001]}\end{array}$ & $\begin{array}{c}0.003^{* * *} \\
{[0.001]}\end{array}$ & $\begin{array}{c}0.009 * * * \\
{[0.001]}\end{array}$ & $\begin{array}{c}0.004^{* * *} \\
{[0.001]}\end{array}$ & $\begin{array}{c}0.001 \\
{[0.001]}\end{array}$ \\
\hline Years in Germany & & $\begin{array}{c}-0.004 \\
{[0.003]}\end{array}$ & & $\begin{array}{c}0.008 \\
{[0.006]}\end{array}$ & $\begin{array}{l}0.010^{*} \\
{[0.005]}\end{array}$ & & $\begin{array}{c}0.024^{* * *} \\
{[0.003]}\end{array}$ & & $\begin{array}{c}0.018^{* * *} \\
{[0.006]}\end{array}$ & $\begin{array}{c}0.009 \\
{[0.006]}\end{array}$ \\
\hline Years in Germany Squared & & $\begin{array}{c}0.000 \\
{[0.000]}\end{array}$ & & $\begin{array}{l}-0.000 \\
{[0.000]}\end{array}$ & $\begin{array}{c}-0.000 \\
{[0.000]}\end{array}$ & & $\begin{array}{c}-0.000 * * * \\
{[0.000]}\end{array}$ & & $\begin{array}{l}-0.000 \\
{[0.000]}\end{array}$ & $\begin{array}{c}0.000 \\
{[0.000]}\end{array}$ \\
\hline Age & $\begin{array}{c}0.092^{* * *} \\
{[0.004]}\end{array}$ & $\begin{array}{c}0.093^{* * *} \\
{[0.004]}\end{array}$ & $\begin{array}{c}0.217^{* * *} \\
{[0.007]}\end{array}$ & $\begin{array}{c}0.227^{* * *} \\
{[0.008]}\end{array}$ & $\begin{array}{c}0.166^{* * * *} \\
{[0.007]}\end{array}$ & $\begin{array}{c}0.027^{* * *} \\
{[0.004]}\end{array}$ & $\begin{array}{c}0.034^{* * *} \\
{[0.004]}\end{array}$ & $\begin{array}{c}0.087^{* * *} \\
{[0.008]}\end{array}$ & $\begin{array}{c}0.102^{* * *} \\
{[0.008]}\end{array}$ & $\begin{array}{c}0.090^{* * *} \\
{[0.008]}\end{array}$ \\
\hline Age Squared & $\begin{array}{c}-0.001^{* * *} \\
{[0.000]}\end{array}$ & $\begin{array}{c}-0.001^{* * *} \\
{[0.000]}\end{array}$ & $\begin{array}{c}-0.003^{* * *} \\
{[0.000]}\end{array}$ & $\begin{array}{c}-0.003^{* * *} \\
{[0.000]}\end{array}$ & $\begin{array}{c}-0.002^{* * *} \\
{[0.000]}\end{array}$ & $\begin{array}{c}-0.000^{* * *} \\
{[0.000]}\end{array}$ & $\begin{array}{c}-0.000 * * * \\
{[0.000]}\end{array}$ & $\begin{array}{c}-0.001^{* * *} \\
{[0.000]}\end{array}$ & $\begin{array}{c}-0.001 * * * \\
{[0.000]}\end{array}$ & $\begin{array}{c}-0.001 * * * \\
{[0.000]}\end{array}$ \\
\hline Medium-skilled & $\begin{array}{c}0.082^{* * *} \\
{[0.008]}\end{array}$ & $\begin{array}{c}0.081 * * * \\
{[0.008]}\end{array}$ & $\begin{array}{c}0.192 * * * \\
{[0.012]}\end{array}$ & $\begin{array}{c}0.185^{* * *} \\
{[0.012]}\end{array}$ & $\begin{array}{c}0.104 * * * \\
{[0.010]}\end{array}$ & $\begin{array}{c}0.203^{* * *} \\
{[0.009]}\end{array}$ & $\begin{array}{c}0.195^{* * *} \\
{[0.009]}\end{array}$ & $\begin{array}{c}0.254 * * * \\
{[0.016]}\end{array}$ & $\begin{array}{c}0.242^{* * *} \\
{[0.016]}\end{array}$ & $\begin{array}{c}0.093^{* * *} \\
{[0.015]}\end{array}$ \\
\hline High-skilled & $\begin{array}{c}0.124^{* * *} \\
{[0.011]}\end{array}$ & $\begin{array}{c}0.124^{* * *} \\
{[0.011]}\end{array}$ & $\begin{array}{c}0.533^{* * *} \\
{[0.023]}\end{array}$ & $\begin{array}{c}0.538^{* * *} \\
{[0.023]}\end{array}$ & $\begin{array}{c}0.406^{* * *} \\
{[0.021]}\end{array}$ & $\begin{array}{c}0.278^{* * *} \\
{[0.013]}\end{array}$ & $\begin{array}{c}0.288^{* * *} \\
{[0.013]}\end{array}$ & $\begin{array}{c}0.598^{* * *} \\
{[0.027]}\end{array}$ & $\begin{array}{c}0.611^{* * *} \\
{[0.026]}\end{array}$ & $\begin{array}{c}0.328^{* * *} \\
{[0.025]}\end{array}$ \\
\hline Year Fixed Effects & Yes & Yes & Yes & Yes & Yes & Yes & Yes & Yes & Yes & Yes \\
\hline State Fixed Effects & Yes & Yes & Yes & Yes & Yes & Yes & Yes & Yes & Yes & Yes \\
\hline State-specific Linear Trends & Yes & Yes & Yes & Yes & Yes & Yes & Yes & Yes & Yes & Yes \\
\hline Region of Origin Fixed Effects & Yes & Yes & Yes & Yes & Yes & Yes & Yes & Yes & Yes & Yes \\
\hline Occupation and Sector Fixed Effects & - & - & No & No & Yes & - & - & No & No & Yes \\
\hline Observations & 15,763 & 15,763 & 13,727 & 13,727 & 13,727 & 16,609 & 16,609 & 11,719 & 11,719 & 11,719 \\
\hline R Squared & 0.167 & 0.168 & 0.333 & 0.336 & 0.509 & 0.134 & 0.141 & 0.144 & 0.151 & 0.265 \\
\hline Mean of Dependent Variable & 0.752 & 0.752 & 7.25 & 7.25 & 7.25 & 0.550 & 0.550 & 6.72 & 6.72 & 6.72 \\
\hline
\end{tabular}

Notes: The table reports OLS estimates of the returns to citizenship for male and female immigrants in Germany. The dependent variables are whether a person is gainfully employed (columns (1)-(2) and (6)-(7)) and the log monthly personal income adjusted to 2005 prices (in columns (3)-(5) and (8)-(10)). The sample includes all immigrants who arrived in Germany between 1976 and 2000 and who were between 16 and 35 yearsold in some year in the 1991-2009 period. We exclude all ethnic Germans, i.e. immigrants with German ancestry who had faster access to German citizenship than regular immigrants. Years since naturalized denote the number of years since an immigrants reports naturalization. All specifications include year and state of current residence fixed effects as well as state-specific linear trends. We also include region of origin fixed effects (traditional EU countries, new EU entrants (EU-12), ex-Yugoslavia, Turkey, Middle East, Asia, Africa, North and South America, Russia and other former Soviet Union republics, other or no citizenship). The omitted education category is low-skilled (without high school or vocational degree). The second and third specifications (columns (2), (4), (5), (7), (9), (10)) include a linear and squared term of years spent in Germany. The third specification (columns (5) and (10)) also includes broad occupation and sector of employment dummies. Standard errors are clustered at the age $x$ arrival cohort level. Statistical significance: *** $p<0.01,{ }^{* *} p<0.05,{ }^{*} p<0.1$.

Source : Microcensus (2007-2009). 
Table 3: Eligibility for Citizenship, Employment and Wage Growth

\begin{tabular}{|c|c|c|c|c|c|c|c|c|c|c|}
\hline & \multicolumn{5}{|c|}{ Male Immigrants } & \multicolumn{5}{|c|}{ Female Immigrants } \\
\hline & \multicolumn{2}{|c|}{ Employment } & \multicolumn{3}{|c|}{ Log Personal Income } & \multicolumn{2}{|c|}{ Employment } & \multicolumn{3}{|c|}{ Log Personal Income } \\
\hline & $(1)$ & $(2)$ & (3) & (4) & (5) & (6) & (7) & (8) & (9) & (10) \\
\hline Years since Eligible & $\begin{array}{c}0.002^{* *} \\
{[0.001]}\end{array}$ & $\begin{array}{c}-0.001 \\
{[0.002]}\end{array}$ & $\begin{array}{c}0.012 * * * \\
{[0.002]}\end{array}$ & $\begin{array}{c}0.003 \\
{[0.004]}\end{array}$ & $\begin{array}{c}0.003 \\
{[0.003]}\end{array}$ & $\begin{array}{c}0.013^{* * *} \\
{[0.001]}\end{array}$ & $\begin{array}{c}0.003 \\
{[0.002]}\end{array}$ & $\begin{array}{c}0.022 * * * \\
{[0.002]}\end{array}$ & $\begin{array}{c}0.014 * * * \\
{[0.004]}\end{array}$ & $\begin{array}{c}0.010 * * \\
{[0.004]}\end{array}$ \\
\hline Years in Germany & & $\begin{array}{l}-0.001 \\
{[0.004]}\end{array}$ & & $\begin{array}{c}0.009 \\
{[0.007]}\end{array}$ & $\begin{array}{c}0.008 \\
{[0.006]}\end{array}$ & & $\begin{array}{c}0.025^{* * *} \\
{[0.004]}\end{array}$ & & $\begin{array}{c}0.009 \\
{[0.007]}\end{array}$ & $\begin{array}{c}0.001 \\
{[0.007]}\end{array}$ \\
\hline Years in Germany Squared & & $\begin{array}{c}0.000 \\
{[0.000]}\end{array}$ & & $\begin{array}{c}-0.000 \\
{[0.000]}\end{array}$ & $\begin{array}{c}-0.000 \\
{[0.000]}\end{array}$ & & $\begin{array}{c}-0.000 * * * \\
{[0.000]}\end{array}$ & & $\begin{array}{c}-0.000 \\
{[0.000]}\end{array}$ & $\begin{array}{c}0.000 \\
{[0.000]}\end{array}$ \\
\hline Age & $\begin{array}{c}0.090 * * * \\
{[0.004]}\end{array}$ & $\begin{array}{c}0.094^{* * *} \\
{[0.004]}\end{array}$ & $\begin{array}{c}0.214^{* * *} \\
{[0.007]}\end{array}$ & $\begin{array}{c}0.224^{* * *} \\
{[0.008]}\end{array}$ & $\begin{array}{c}0.164^{* * *} \\
{[0.008]}\end{array}$ & $\begin{array}{c}0.024^{* * *} \\
{[0.004]}\end{array}$ & $\begin{array}{c}0.032 * * * \\
{[0.004]}\end{array}$ & $\begin{array}{c}0.084 * * * \\
{[0.007]}\end{array}$ & $\begin{array}{c}0.092^{* * *} \\
{[0.008]}\end{array}$ & $\begin{array}{c}0.083^{* * *} \\
{[0.008]}\end{array}$ \\
\hline Age Squared & $\begin{array}{c}-0.001 * * * \\
{[0.000]}\end{array}$ & $\begin{array}{c}-0.001 * * * \\
{[0.000]}\end{array}$ & $\begin{array}{c}-0.003^{* * *} \\
{[0.000]}\end{array}$ & $\begin{array}{c}-0.003 * * * \\
{[0.000]}\end{array}$ & $\begin{array}{c}-0.002 * * * \\
{[0.000]}\end{array}$ & $\begin{array}{c}-0.000 * * * \\
{[0.000]}\end{array}$ & $\begin{array}{c}-0.000 * * * \\
{[0.000]}\end{array}$ & $\begin{array}{c}-0.001 * * * \\
{[0.000]}\end{array}$ & $\begin{array}{c}-0.001 * * * \\
{[0.000]}\end{array}$ & $\begin{array}{c}-0.001 * * * \\
{[0.000]}\end{array}$ \\
\hline Medium-skilled & $\begin{array}{c}0.085^{* * *} \\
{[0.008]}\end{array}$ & $\begin{array}{c}0.084^{* * *} \\
{[0.008]}\end{array}$ & $\begin{array}{c}0.189 * * * \\
{[0.012]}\end{array}$ & $\begin{array}{c}0.189 * * * \\
{[0.012]}\end{array}$ & $\begin{array}{c}0.105^{* * *} \\
{[0.010]}\end{array}$ & $\begin{array}{c}0.199 * * * \\
{[0.009]}\end{array}$ & $\begin{array}{c}0.199 * * * \\
{[0.009]}\end{array}$ & $\begin{array}{c}0.247^{* * *} \\
{[0.016]}\end{array}$ & $\begin{array}{c}0.245^{* * *} \\
{[0.016]}\end{array}$ & $\begin{array}{c}0.093^{* * *} \\
{[0.015]}\end{array}$ \\
\hline High-skilled & $\begin{array}{c}0.128 * * * \\
{[0.011]}\end{array}$ & $\begin{array}{c}0.127^{* * *} \\
{[0.011]}\end{array}$ & $\begin{array}{c}0.542 * * * \\
{[0.023]}\end{array}$ & $\begin{array}{c}0.543^{* * *} \\
{[0.023]}\end{array}$ & $\begin{array}{c}0.407^{* * *} \\
{[0.021]}\end{array}$ & $\begin{array}{c}0.287^{* * *} \\
{[0.013]}\end{array}$ & $\begin{array}{c}0.291 * * * \\
{[0.013]}\end{array}$ & $\begin{array}{c}0.616^{* * *} \\
{[0.026]}\end{array}$ & $\begin{array}{c}0.616^{* * *} \\
{[0.026]}\end{array}$ & $\begin{array}{c}0.329 * * * \\
{[0.025]}\end{array}$ \\
\hline Year Fixed Effects & Yes & Yes & Yes & Yes & Yes & Yes & Yes & Yes & Yes & Yes \\
\hline State Fixed Effects & Yes & Yes & Yes & Yes & Yes & Yes & Yes & Yes & Yes & Yes \\
\hline State-specific Linear Trends & Yes & Yes & Yes & Yes & Yes & Yes & Yes & Yes & Yes & Yes \\
\hline Region of Origin Fixed Effects & Yes & Yes & Yes & Yes & Yes & Yes & Yes & Yes & Yes & Yes \\
\hline Occupation and Sector Fixed Effects & - & - & No & No & Yes & - & - & No & No & Yes \\
\hline Observations & 15,763 & 15,763 & 13,727 & 13,727 & 13,727 & 16,609 & 16,609 & 11,719 & 11,719 & 11,719 \\
\hline R Squared & 0.165 & 0.166 & 0.334 & 0.335 & 0.508 & 0.137 & 0.140 & 0.150 & 0.151 & 0.265 \\
\hline Mean of Dependent Variable & 0.752 & 0.752 & 7.25 & 7.25 & 7.25 & 0.550 & 0.550 & 6.72 & 6.72 & 6.72 \\
\hline
\end{tabular}


Table 4: Naturalization, Eligibility and Social Assistance

\begin{tabular}{|c|c|c|c|c|c|c|c|c|}
\hline & \multicolumn{4}{|c|}{ Male Immigrants } & \multicolumn{4}{|c|}{ Female Immigrants } \\
\hline & \multirow{3}{*}{\multicolumn{2}{|c|}{$\frac{\frac{\text { Any Social }}{\text { Assistance }}}{\text { OLS }}$}} & \multirow{3}{*}{\multicolumn{2}{|c|}{$\frac{\frac{\text { Unempl. Benefits }}{\text { or Welfare Benefits }}}{\text { OLS }}$}} & \multirow{3}{*}{\multicolumn{2}{|c|}{$\frac{\frac{\text { Any Social }}{\text { Assistance }}}{\text { OLS }}$}} & \multirow{3}{*}{\multicolumn{2}{|c|}{$\frac{\frac{\text { Unempl. Benefits }}{\text { or Welfare Benefits }}}{\text { OLS }}$}} \\
\hline & & & & & & & & \\
\hline & & & & & & & & \\
\hline & $(1)$ & $(2)$ & (3) & (4) & (5) & $(6)$ & $(7)$ & $(8)$ \\
\hline \multirow[t]{2}{*}{ Years since Naturalized } & $-0.003^{* * *}$ & $-0.002 * * *$ & 0.002 & 0.002 & $-0.001 * * *$ & $-0.002 * * *$ & 0.002 & 0.001 \\
\hline & {$[0.000]$} & {$[0.001]$} & [0.002] & {$[0.002]$} & {$[0.000]$} & {$[0.000]$} & {$[0.001]$} & {$[0.002]$} \\
\hline Observations & 15,756 & 15,756 & 2,369 & 2,369 & 16,602 & 16,602 & 1,877 & 1,877 \\
\hline \multirow[t]{2}{*}{ R Squared } & 0.085 & 0.085 & 0.108 & 0.109 & 0.057 & 0.058 & 0.100 & 0.102 \\
\hline & \multicolumn{2}{|c|}{ Reduced Form } & \multicolumn{2}{|c|}{ Reduced Form } & \multicolumn{2}{|c|}{ Reduced Form } & \multicolumn{2}{|c|}{ Reduced Form } \\
\hline \multirow[t]{2}{*}{ Years since Eligible } & $-0.001 *$ & $0.0033^{* *}$ & -0.002 & $-0.011 * *$ & $0.002 * *$ & 0.0027 & $0.004^{* *}$ & -0.002 \\
\hline & {$[0.001]$} & {$[0.0016]$} & {$[0.002]$} & {$[0.005]$} & {$[0.001]$} & {$[0.0017]$} & {$[0.002]$} & {$[0.005]$} \\
\hline Observations & 15,756 & 15,756 & 2,369 & 2,369 & 16,602 & 16,602 & 1,877 & 1,877 \\
\hline R Squared & 0.084 & 0.084 & 0.108 & 0.109 & 0.057 & 0.057 & 0.100 & 0.101 \\
\hline Individual Characteristics & Yes & Yes & Yes & Yes & Yes & Yes & Yes & Yes \\
\hline Years in Germany & No & Yes & No & Yes & No & Yes & No & Yes \\
\hline Region of Origin Fixed Effects & Yes & Yes & Yes & Yes & Yes & Yes & Yes & Yes \\
\hline Year Fixed Effects & Yes & Yes & Yes & Yes & Yes & Yes & Yes & Yes \\
\hline State Fixed Effects & Yes & Yes & Yes & Yes & Yes & Yes & Yes & Yes \\
\hline State-specific Linear Trends & Yes & Yes & Yes & Yes & Yes & Yes & Yes & Yes \\
\hline Mean of Dependent Variable & 0.154 & 0.154 & 0.776 & 0.776 & 0.114 & 0.114 & 0.865 & 0.865 \\
\hline \multicolumn{9}{|c|}{$\begin{array}{l}\text { Notes: The table reports OLS (top panel) and reduced-form estimates (bottom panel) of the returns to citizenship for male and female immigrants in Germany. The } \\
\text { dependent variable in columns (1), (2), (5) and (6) is defined as one if a person receives unemployment benefits (Arbeitlosengeld I) or social assistance (Arbeitslosengeld II) } \\
\text { In columns (3), (4), (7) and (8), the dependent variable is one if an immigrant receives unemployment assistance and zero if he receives welfare benefits. The sample } \\
\text { includes all immigrants who arrived in Germany between } 1976 \text { and } 2000 \text { and who were between the ages of } 16 \text { and } 35 \text { in some year in the } 1991-2009 \text { period. We exclude al } \\
\text { ethnic Germans, i.e. immigrants with German ancestry who had faster access to German citizenship than regular immigrants. Years since naturalized denote the number of } \\
\text { years since an immigrant reports naturalization. All specifications include the same individual characteristics as earlier tables (age, education), current year and state of } \\
\text { current residence fixed effects as well as state-specific linear trends. We also include } 10 \text { region of origin fixed effects (traditional EU countries, new EU entrants (EU-12), ex- } \\
\text { Yugoslavia, Turkey, Middle East, Asia, Africa, North and South America, Russia and other former Soviet Union republics, other or no citizenship). The second specification } \\
\text { (columns (2), (4), (6) and (8)) includes a linear and squared term of years spent in Germany. Standard errors are clustered at the age } x \text { arrival cohort level. Statistical } \\
\text { significance: }{ }^{* * *} p<0.01, * * 0<0.05, * p<0.1 \text {. }\end{array}$} \\
\hline
\end{tabular}


Table 5: Citizenship and Type of Employment

\begin{tabular}{|c|c|c|c|c|c|c|c|c|c|c|}
\hline & & \multicolumn{3}{|c|}{ Male Immigrants } & \multicolumn{6}{|c|}{ Female Immigrants } \\
\hline & $\begin{array}{c}\frac{\text { Public Sector }}{\text { OLS }} \\
(1) \\
\end{array}$ & $\begin{array}{c}\text { White Collar } \\
\text { OLS } \\
(2) \\
\end{array}$ & $\begin{array}{c}\frac{\text { Self-Employed }}{\text { OLS }} \\
(3) \\
\end{array}$ & $\begin{array}{c}\frac{\text { Permanent Contract }}{\text { OLS }} \\
(4) \\
\end{array}$ & $\begin{array}{c}\frac{\text { Job Tenure }}{\text { OLS }} \\
(5) \\
\end{array}$ & $\begin{array}{c}\frac{\text { Public Sector }}{\text { OLS }} \\
(6) \\
\end{array}$ & $\begin{array}{c}\text { White Collar } \\
\text { OLS } \\
(7) \\
\end{array}$ & $\begin{array}{c}\frac{\text { Self-Employed }}{\text { OLS }} \\
(8) \\
\end{array}$ & $\begin{array}{c}\frac{\text { Permanent Contract }}{\text { OLS }} \\
(9) \\
\end{array}$ & $\begin{array}{c}\frac{\text { Job Tenure }}{\text { OLS }} \\
(10) \\
\end{array}$ \\
\hline Years since Naturalized & $\begin{array}{c}0.001^{* * *} \\
{[0.000]}\end{array}$ & $\begin{array}{c}0.004^{* * *} \\
{[0.001]}\end{array}$ & $\begin{array}{c}0.000 \\
{[0.001]}\end{array}$ & $\begin{array}{l}-0.000 \\
{[0.001]}\end{array}$ & $\begin{array}{c}0.007 \\
{[0.011]}\end{array}$ & $\begin{array}{c}0.002^{* * *} \\
{[0.001]}\end{array}$ & $\begin{array}{c}0.003^{* * *} \\
{[0.001]}\end{array}$ & $\begin{array}{c}0.001 \\
{[0.000]}\end{array}$ & $\begin{array}{l}-0.001 \\
{[0.001]}\end{array}$ & $\begin{array}{c}0.009 \\
{[0.009]}\end{array}$ \\
\hline $\begin{array}{l}\text { Observations } \\
\text { R Squared }\end{array}$ & $\begin{array}{c}11,847 \\
0.027\end{array}$ & $\begin{array}{l}9,267 \\
0.204\end{array}$ & $\begin{array}{c}11,850 \\
0.052\end{array}$ & $\begin{array}{c}10,322 \\
0.191\end{array}$ & $\begin{array}{c}11,254 \\
0.318\end{array}$ & $\begin{array}{l}9,129 \\
0.028\end{array}$ & $\begin{array}{l}7,758 \\
0.294\end{array}$ & $\begin{array}{l}9,132 \\
0.048\end{array}$ & $\begin{array}{l}8,279 \\
0.159\end{array}$ & $\begin{array}{l}8,674 \\
0.213\end{array}$ \\
\hline & Reduced Form & Reduced Form & Reduced Form & Reduced Form & Reduced Form & $\begin{array}{l}\text { Reduced Form } \\
\end{array}$ & Reduced Form & Reduced Form & Reduced Form & Reduced Form \\
\hline Years since Eligible & $\begin{array}{c}0.001 \\
{[0.001]}\end{array}$ & $\begin{array}{c}-0.003 \\
{[0.003]}\end{array}$ & $\begin{array}{c}-0.002 \\
{[0.002]}\end{array}$ & $\begin{array}{c}0.005^{* * *} \\
{[0.002]}\end{array}$ & $\begin{array}{l}0.059 * \\
{[0.036]}\end{array}$ & $\begin{array}{c}0.001 \\
{[0.002]}\end{array}$ & $\begin{array}{c}0.003 \\
{[0.003]}\end{array}$ & $\begin{array}{c}-0.000 \\
{[0.002]}\end{array}$ & $\begin{array}{l}0.005^{* *} \\
{[0.002]}\end{array}$ & $\begin{array}{c}0.077 * * * \\
{[0.027]}\end{array}$ \\
\hline $\begin{array}{l}\text { Observations } \\
\text { R Squared }\end{array}$ & $\begin{array}{c}11,847 \\
0.022\end{array}$ & $\begin{array}{l}9,267 \\
0.202\end{array}$ & $\begin{array}{c}11,850 \\
0.053\end{array}$ & $\begin{array}{c}10,322 \\
0.191\end{array}$ & $\begin{array}{c}11,254 \\
0.318\end{array}$ & $\begin{array}{l}9,129 \\
0.023\end{array}$ & $\begin{array}{l}7,758 \\
0.293\end{array}$ & $\begin{array}{l}9,132 \\
0.047\end{array}$ & $\begin{array}{l}8,279 \\
0.160\end{array}$ & $\begin{array}{l}8,674 \\
0.213\end{array}$ \\
\hline Individual Characteristics & Yes & Yes & Yes & Yes & Yes & Yes & Yes & Yes & Yes & Yes \\
\hline Years in Germany & Yes & Yes & Yes & Yes & Yes & Yes & Yes & Yes & Yes & Yes \\
\hline Region of Origin Fixed Effects & Yes & Yes & Yes & Yes & Yes & Yes & Yes & Yes & Yes & Yes \\
\hline Year Fixed Effects & Yes & Yes & Yes & Yes & Yes & Yes & Yes & Yes & Yes & Yes \\
\hline State Fixed Effects & Yes & Yes & Yes & Yes & Yes & Yes & Yes & Yes & Yes & Yes \\
\hline State-specific Linear Trends & Yes & Yes & Yes & Yes & Yes & Yes & Yes & Yes & Yes & Yes \\
\hline Mean of Dependent Variable & 0.046 & 0.378 & 0.124 & 0.834 & 7.839 & 0.114 & 0.612 & 0.074 & 0.815 & 6.602 \\
\hline
\end{tabular}

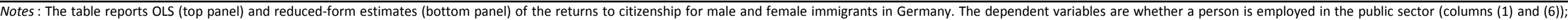

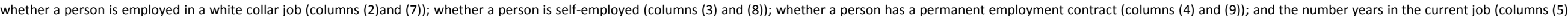

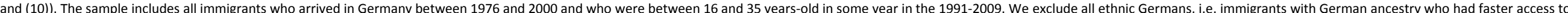

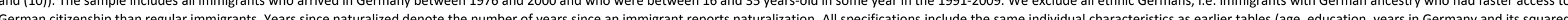

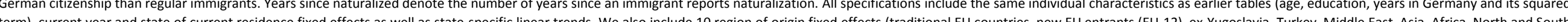
America, Russia and other former Soviet Union republics, other or no citizenship). Standard errors are clustered at the age $x$ arrival cohort level. Statistical significance: *** $p<0.01, * * p<0.05 * 0<0.1$.

Source : Microcensus (2007-2009). 
Table 6: Citizenship Acquisition and Language Ability

\begin{tabular}{|c|c|c|c|c|c|c|c|c|}
\hline & \multicolumn{4}{|c|}{ Male Immigrants } & \multicolumn{4}{|c|}{ Female Immigrants } \\
\hline & \multirow{2}{*}{\multicolumn{2}{|c|}{$\frac{\text { Write in German }}{\text { OLS }}$}} & \multirow{2}{*}{\multicolumn{2}{|c|}{$\frac{\text { Speak German }}{\text { OLS }}$}} & \multirow{2}{*}{\multicolumn{2}{|c|}{$\frac{\text { Write in German }}{\text { OLS }}$}} & \multirow{2}{*}{\multicolumn{2}{|c|}{$\frac{\text { Speak German }}{\text { OLS }}$}} \\
\hline & & & & & & & & \\
\hline & (1) & (2) & (3) & (4) & (5) & (6) & (7) & (8) \\
\hline \multirow[t]{2}{*}{ Years since Naturalized } & $0.029 * * *$ & -0.001 & $0.022^{* * *}$ & -0.004 & $0.023^{* * *}$ & -0.004 & $0.015^{* * *}$ & $-0.011 * * *$ \\
\hline & {$[0.006]$} & {$[0.005]$} & {$[0.005]$} & [0.004] & [0.004] & [0.004] & {$[0.004]$} & {$[0.004]$} \\
\hline Observations & 3,908 & 3,908 & 3,923 & 3,923 & 3,952 & 3,952 & 4,225 & 4,225 \\
\hline \multirow[t]{3}{*}{ R Squared } & 0.231 & 0.368 & 0.169 & 0.350 & 0.347 & 0.443 & 0.367 & 0.458 \\
\hline & \multicolumn{2}{|c|}{ Write in German } & \multicolumn{2}{|c|}{ Speak German } & \multicolumn{2}{|c|}{ Write in German } & \multicolumn{2}{|c|}{ Speak German } \\
\hline & \multicolumn{2}{|c|}{ Reduced Form } & \multicolumn{2}{|c|}{ Reduced Form } & \multicolumn{2}{|c|}{ Reduced Form } & \multicolumn{2}{|c|}{ Reduced Form } \\
\hline \multirow[t]{2}{*}{ Years since Eligible } & $0.111^{* * *}$ & -0.001 & $0.099 * * *$ & -0.000 & $0.089 * * *$ & $-0.021 * *$ & $0.077^{* * *}$ & $-0.041 * * *$ \\
\hline & [0.006] & [0.010] & {$[0.005]$} & {$[0.008]$} & {$[0.006]$} & [0.009] & {$[0.005]$} & {$[0.008]$} \\
\hline Observations & 3,908 & 3,908 & 3,923 & 3,923 & 4,225 & 4,225 & 4,235 & 4,235 \\
\hline R Squared & 0.294 & 0.368 & 0.253 & 0.350 & 0.398 & 0.459 & 0.338 & 0.434 \\
\hline Individual Characteristics & Yes & Yes & Yes & Yes & Yes & Yes & Yes & Yes \\
\hline Years in Germany & No & Yes & No & Yes & No & Yes & No & Yes \\
\hline Region of Origin Fixed Effects & Yes & Yes & Yes & Yes & Yes & Yes & Yes & Yes \\
\hline Year Fixed Effects & Yes & Yes & Yes & Yes & Yes & Yes & Yes & Yes \\
\hline State Fixed Effects & Yes & Yes & Yes & Yes & Yes & Yes & Yes & Yes \\
\hline State-specific Linear Trends & Yes & Yes & Yes & Yes & Yes & Yes & Yes & Yes \\
\hline Mean of Dependent Variable & 2.29 & 2.29 & 2.77 & 2.77 & 2.00 & 2.00 & 2.48 & 2.48 \\
\hline \multicolumn{9}{|c|}{$\begin{array}{l}\text { Notes: The table reports OLS (top panel) and reduced-form estimates (bottom panel) of the returns to citizenship for male and female immigrants in Germany. The dependent variables are } \\
\text { self-assessed language skills in writing and speaking German respectively (reported on a scale from } 0=\text { Not at all to } 4=\text { Very well). The sample includes all immigrants who arrived in Germany } \\
\text { between } 1976 \text { and } 2000 \text { and who were between the ages of } 16 \text { and } 35 \text { in some year in the } 1991-2009 \text { period. We exclude all ethnic Germans, i.e. immigrants with German ancestry who had } \\
\text { faster access to German citizenship than regular immigrants. All specifications include the same individual characteristics as earlier tables (age, education), current year and state of current } \\
\text { residence fixed effects as well as state-specific linear trends. We also include } 10 \text { region of origin fixed effects (traditional EU countries, new EU entrants (EU-12), ex-Yugoslavia, Turkey, } \\
\text { Middle East, Asia, Africa, North and South America, Russia and other former Soviet Union republics, other or no citizenship). The second specification (columns (2), (4), (6) and (8)) includes a } \\
\text { linear and squared term of years spent in Germany. Standard errors are clustered at the age x arrival cohort level. Statistical significance: }{ }^{* * *} p<0.01,{ }^{* *} p<0.05,{ }^{*} p<0.1 .\end{array}$} \\
\hline
\end{tabular}

Source : Socio-Economic Panel (1984-1987, 1989, 1991, 1993, 1995, 1997, 1999, 2001, 2003, 2005, 2007-2009) 


\begin{tabular}{|c|c|c|c|c|c|c|}
\hline & \multicolumn{6}{|c|}{ Reduced-form Results } \\
\hline & \multicolumn{2}{|c|}{ Region of Origin } & \multicolumn{2}{|c|}{ Source GDP } & \multicolumn{2}{|c|}{ Education } \\
\hline & (1) & $(2)$ & (3) & (4) & $(5)$ & (6) \\
\hline Years Eligible for Naturalization & $\begin{array}{c}0.005 \\
{[0.003]}\end{array}$ & $\begin{array}{c}-0.004 \\
{[0.005]}\end{array}$ & $\begin{array}{c}0.015^{* * *} \\
{[0.002]}\end{array}$ & $\begin{array}{c}0.005 \\
{[0.004]}\end{array}$ & $\begin{array}{c}0.012^{* * *} \\
{[0.002]}\end{array}$ & $\begin{array}{c}0.002 \\
{[0.004]}\end{array}$ \\
\hline Years Eligible*new EU12 & $\begin{array}{c}0.006 \\
{[0.005]}\end{array}$ & $\begin{array}{c}0.007 \\
{[0.005]}\end{array}$ & & & & \\
\hline Years Eligible*Ex-Yugoslavia & $\begin{array}{c}0.007 \\
{[0.006]}\end{array}$ & $\begin{array}{c}0.008 \\
{[0.006]}\end{array}$ & & & & \\
\hline Years Eligible*Turkey & $\begin{array}{c}0.003 \\
{[0.004]}\end{array}$ & $\begin{array}{c}0.002 \\
{[0.004]}\end{array}$ & & & & \\
\hline Years Eligible*Middle East & $\begin{array}{c}0.019 * * * \\
{[0.005]}\end{array}$ & $\begin{array}{c}0.020^{* * *} \\
{[0.005]}\end{array}$ & & & & \\
\hline Years Eligible*Africa & $\begin{array}{c}0.030^{* * *} \\
{[0.006]}\end{array}$ & $\begin{array}{c}0.032^{* * *} \\
{[0.006]}\end{array}$ & & & & \\
\hline Years Eligible*Asia & $\begin{array}{c}0.008 \\
{[0.006]}\end{array}$ & $\begin{array}{c}0.009 \\
{[0.006]}\end{array}$ & & & & \\
\hline Years Eligible*(North/South America) & $\begin{array}{c}0.006 \\
{[0.011]}\end{array}$ & $\begin{array}{c}0.006 \\
{[0.011]}\end{array}$ & & & & \\
\hline Years Eligible*(Russia and Former SU) & $\begin{array}{c}0.017^{* * *} \\
{[0.006]}\end{array}$ & $\begin{array}{c}0.019 * * * \\
{[0.006]}\end{array}$ & & & & \\
\hline Years Eligible*(Other or No Passport) & $\begin{array}{c}0.020^{* *} \\
{[0.010]}\end{array}$ & $\begin{array}{c}0.021^{* *} \\
{[0.010]}\end{array}$ & & & & \\
\hline GDP Source Country & & & $\begin{array}{c}0.009 * * * \\
{[0.002]}\end{array}$ & $\begin{array}{c}0.009 * * * \\
{[0.002]}\end{array}$ & & \\
\hline Years Eligible*GDP Source Country & & & $\begin{array}{c}-0.001^{* * *} \\
{[0.000]}\end{array}$ & $\begin{array}{c}-0.001^{* * *} \\
{[0.000]}\end{array}$ & & \\
\hline Years Eligible*Medium-skilled & & & & & $\begin{array}{c}0.000 \\
{[0.002]}\end{array}$ & $\begin{array}{c}0.000 \\
{[0.003]}\end{array}$ \\
\hline Years Eligible*High-skilled & & & & & $\begin{array}{c}0.000 \\
{[0.004]}\end{array}$ & $\begin{array}{c}0.001 \\
{[0.004]}\end{array}$ \\
\hline Individual Characteristics & Yes & Yes & Yes & Yes & Yes & Yes \\
\hline Years in Germany & No & Yes & No & Yes & No & Yes \\
\hline Region of Origin Fixed Effects & Yes & Yes & No & No & Yes & Yes \\
\hline Year Fixed Effects & Yes & Yes & Yes & Yes & Yes & Yes \\
\hline State Fixed Effects & Yes & Yes & Yes & Yes & Yes & Yes \\
\hline State-specific Linear Trends & Yes & Yes & Yes & Yes & Yes & Yes \\
\hline Observations & 13,727 & 13,727 & 11,405 & 11,405 & 13,727 & 13,727 \\
\hline R Squared & 0.337 & 0.337 & 0.331 & 0.332 & 0.334 & 0.335 \\
\hline
\end{tabular}

Notes: The table reports reduced-form estimates of the returns to citizenship eligibility in Germany. The dependent variable is log monthly personal income (adjusted to 2005 prices). The sample includes all immigrants who arrived in Germany between 1976 and 2000 and who were between the ages of 16 and 35 in some year in the 1991-2009 period. We exclude all ethnic Germans, i.e. immigrants with German ancestry who had faster access to German citizenship than regular immigrants. Years since eligible denote the number of years since an immigrants became eligible for naturalization after the 1991 and 2000 immigration reforms. All specifications include the same individual characteristics (age, education) as before, year and state of current residence fixed effects as well as state-specific linear trends. We also include 10 region of origin fixed effects (traditional EU countries, new EU entrants (EU-12), ex-Yugoslavia, Turkey, Middle East, Asia, Africa, North and South America, Russia and other former Soviet Union republics, other or no citizenship). The second specification adds a linear and squared term of years spent in Germany. Standard errors are clustered at the age $\mathrm{x}$ arrival cohort level. Statistical significance: ${ }^{* * *} \mathrm{p}<0.01,{ }^{* *} \mathrm{p}<0.05,{ }^{*} \mathrm{p}<0.1$.

Source : Microcensus (2007-2009). 


\begin{tabular}{|c|c|c|c|c|c|c|}
\hline & \multicolumn{6}{|c|}{ Reduced-form Results } \\
\hline & \multicolumn{2}{|c|}{ Region of Origin } & \multicolumn{2}{|c|}{ Source GDP } & \multicolumn{2}{|c|}{ Education } \\
\hline & $(1)$ & $(2)$ & (3) & (4) & (5) & (6) \\
\hline Years Eligible for Naturalization & $\begin{array}{c}0.012 * * * \\
{[0.004]}\end{array}$ & $\begin{array}{c}0.003 \\
{[0.006]}\end{array}$ & $\begin{array}{c}0.027 * * * \\
{[0.003]}\end{array}$ & $\begin{array}{c}0.022 * * * \\
{[0.005]}\end{array}$ & $\begin{array}{c}0.024 * * * \\
{[0.002]}\end{array}$ & $\begin{array}{c}0.016 * * * \\
{[0.005]}\end{array}$ \\
\hline Years Eligible*new EU12 & $\begin{array}{c}0.016^{* * *} \\
{[0.006]}\end{array}$ & $\begin{array}{c}0.017 * * * \\
{[0.006]}\end{array}$ & & & & \\
\hline Years Eligible*Ex-Yugoslavia & $\begin{array}{c}0.022^{* * *} \\
{[0.006]}\end{array}$ & $\begin{array}{c}0.022 * * * \\
{[0.006]}\end{array}$ & & & & \\
\hline Years Eligible*Turkey & $\begin{array}{c}0.009 * * \\
{[0.005]}\end{array}$ & $\begin{array}{l}0.009 * \\
{[0.005]}\end{array}$ & & & & \\
\hline Years Eligible*Middle East & $\begin{array}{c}0.023 * * * \\
{[0.007]}\end{array}$ & $\begin{array}{c}0.023^{* * *} \\
{[0.008]}\end{array}$ & & & & \\
\hline Years Eligible*Africa & $\begin{array}{l}-0.014^{*} \\
{[0.008]}\end{array}$ & $\begin{array}{c}-0.014^{*} \\
{[0.008]}\end{array}$ & & & & \\
\hline Years Eligible*Asia & $\begin{array}{l}0.016^{* *} \\
{[0.008]}\end{array}$ & $\begin{array}{c}0.016^{* *} \\
{[0.008]}\end{array}$ & & & & \\
\hline Years Eligible*(North/South America) & $\begin{array}{c}0.005 \\
{[0.009]}\end{array}$ & $\begin{array}{c}0.005 \\
{[0.009]}\end{array}$ & & & & \\
\hline Years Eligible*(Russia and Former SU) & $\begin{array}{c}0.015^{* *} \\
{[0.007]}\end{array}$ & $\begin{array}{c}0.017^{* *} \\
{[0.008]}\end{array}$ & & & & \\
\hline Years Eligible*(Other or No Passport) & $\begin{array}{c}0.019 \\
{[0.013]}\end{array}$ & $\begin{array}{c}0.020 \\
{[0.013]}\end{array}$ & & & & \\
\hline GDP Source Country & & & $\begin{array}{c}0.008^{* * *} \\
{[0.002]}\end{array}$ & $\begin{array}{c}0.008^{* * *} \\
{[0.002]}\end{array}$ & & \\
\hline Years Eligible*GDP Source Country & & & $\begin{array}{l}-0.000^{*} \\
{[0.000]}\end{array}$ & $\begin{array}{c}-0.000^{*} \\
{[0.000]}\end{array}$ & & \\
\hline Years Eligible*Medium-skilled & & & & & $\begin{array}{l}-0.005 \\
{[0.003]}\end{array}$ & $\begin{array}{l}-0.005 \\
{[0.003]}\end{array}$ \\
\hline Years Eligible*High-skilled & & & & & $\begin{array}{c}0.003 \\
{[0.006]}\end{array}$ & $\begin{array}{c}0.003 \\
{[0.006]}\end{array}$ \\
\hline Individual Characteristics & Yes & Yes & Yes & Yes & Yes & Yes \\
\hline Years in Germany & No & Yes & No & Yes & No & Yes \\
\hline Region of Origin Fixed Effects & Yes & Yes & No & No & Yes & Yes \\
\hline Year Fixed Effects & Yes & Yes & Yes & Yes & Yes & Yes \\
\hline State Fixed Effects & Yes & Yes & Yes & Yes & Yes & Yes \\
\hline State-specific Linear Trends & Yes & Yes & Yes & Yes & Yes & Yes \\
\hline Observations & 11,719 & 11,719 & 9,892 & 9,892 & 11,719 & 11,719 \\
\hline R Squared & 0.153 & 0.153 & 0.147 & 0.147 & 0.151 & 0.151 \\
\hline
\end{tabular}

Notes: The table reports reduced-form estimates of the returns to citizenship eligibility in Germany. The dependent variable is log monthly personal income (adjusted to 2005 prices). The sample includes all immigrants who arrived in Germany between 1976 and 2000 and who were between the ages of 16 and 35 in some year in the 1991-2009 period. We exclude all ethnic Germans, i.e. immigrants with German ancestry who had faster access to German citizenship than regular immigrants. Years since eligible denote the number of years since an immigrants became eligible for naturalization after the 1991 and 2000 immigration reforms. All specifications include the same individual characteristics (age, education) as before, year and state of current residence fixed effects as well as state-specific linear trends. We also include 10 region of origin fixed effects (traditional EU countries, new EU entrants (EU-12), ex-Yugoslavia, Turkey, Middle East, Asia, Africa, North and South America, Russia and other former Soviet Union republics, other or no citizenship). The second specification adds a linear and squared term of years spent in Germany. Standard errors are clustered at the age $x$ arrival cohort level. Statistical significance: $* * * p<0.01, * * p<0.05, * p<0.1$.

Source : Microcensus (2007-2009). 
Table 8: Returns to Citizenship for Different Immigration Waves to Germany

\begin{tabular}{|c|c|c|c|c|c|c|c|c|}
\hline \multirow{4}{*}{ Y: Log Personal Income } & \multicolumn{4}{|c|}{ Male Immigrants } & \multicolumn{4}{|c|}{ Female Immigrants } \\
\hline & \multirow{2}{*}{\multicolumn{2}{|c|}{$\begin{array}{c}\frac{\text { Guest Worker Immigrants }}{\text { (arrived 1976-1989) }} \\
\text { OLS }\end{array}$}} & \multirow{2}{*}{\multicolumn{2}{|c|}{$\begin{array}{c}\frac{\text { Recent Immigrants }}{\text { (arrived 1990-2000) }} \\
\text { OLS }\end{array}$}} & \multirow{2}{*}{\multicolumn{2}{|c|}{$\begin{array}{c}\frac{\text { Guest Worker Immigrants }}{\text { (arrived 1976-1989) }} \\
\text { OLS }\end{array}$}} & \multirow{2}{*}{\multicolumn{2}{|c|}{$\begin{array}{c}\frac{\text { Recent Immigrants }}{\text { (arrived 1990-2000) }} \\
\text { OLS }\end{array}$}} \\
\hline & & & & & & & & \\
\hline & $(1)$ & $(2)$ & (3) & $(4)$ & $(5)$ & (6) & (7) & (8) \\
\hline \multirow[t]{2}{*}{ Years since Naturalized } & $0.003 * * *$ & $0.003^{* *}$ & $0.008^{* * *}$ & $0.005^{* *}$ & $0.005^{* * *}$ & $0.004 * * *$ & $0.007 * * *$ & 0.003 \\
\hline & {$[0.001]$} & {$[0.001]$} & {$[0.002]$} & {$[0.002]$} & {$[0.001]$} & {$[0.001]$} & [0.002] & [0.002] \\
\hline Observations & 5,715 & 5,715 & 8,012 & 8,012 & 4,477 & 4,477 & 7,242 & 7,242 \\
\hline \multirow[t]{3}{*}{ R Squared } & 0.218 & 0.218 & 0.386 & 0.386 & 0.115 & 0.118 & 0.168 & 0.172 \\
\hline & \multirow{2}{*}{\multicolumn{2}{|c|}{$\begin{array}{c}\frac{\text { Guest Worker Immigrants }}{\text { (arrived 1976-1989) }} \\
\text { Reduced Form }\end{array}$}} & \multirow{2}{*}{\multicolumn{2}{|c|}{$\begin{array}{c}\frac{\text { Recent Immigrants }}{\text { (arrived 1990-2000) }} \\
\text { Reduced Form }\end{array}$}} & \multirow{2}{*}{\multicolumn{2}{|c|}{$\begin{array}{c}\frac{\text { Guest Worker Immigrants }}{\text { (arrived 1976-1989) }} \\
\text { Reduced Form }\end{array}$}} & \multirow{2}{*}{\multicolumn{2}{|c|}{$\begin{array}{c}\frac{\text { Recent Immigrants }}{\text { (arrived 1990-2000) }} \\
\text { Reduced Form }\end{array}$}} \\
\hline & & & & & & & & \\
\hline \multirow[t]{2}{*}{ Years since Eligible } & 0.003 & -0.000 & $0.019 * * *$ & $0.030 * * *$ & $0.016 * * *$ & $0.012 * *$ & $0.027 * * *$ & $0.044 * * *$ \\
\hline & {$[0.003]$} & {$[0.004]$} & [0.003] & {$[0.010]$} & {$[0.003]$} & {$[0.005]$} & {$[0.003]$} & {$[0.010]$} \\
\hline Observations & 5,715 & 5,715 & 8,012 & 8,012 & 4,477 & 4,477 & 7,242 & 7,242 \\
\hline R Squared & 0.217 & 0.217 & 0.386 & 0.386 & 0.118 & 0.118 & 0.173 & 0.174 \\
\hline Individual Characteristics & Yes & Yes & Yes & Yes & Yes & Yes & Yes & Yes \\
\hline Years in Germany & No & Yes & No & Yes & No & Yes & No & Yes \\
\hline Region of Origin Fixed Effects & Yes & Yes & Yes & Yes & Yes & Yes & Yes & Yes \\
\hline Year Fixed Effects & Yes & Yes & Yes & Yes & Yes & Yes & Yes & Yes \\
\hline State Fixed Effects & Yes & Yes & Yes & Yes & Yes & Yes & Yes & Yes \\
\hline State-specific Linear Trends & Yes & Yes & Yes & Yes & Yes & Yes & Yes & Yes \\
\hline Mean of Dependent Variable & 7.36 & 7.36 & 7.17 & 7.17 & 6.79 & 6.79 & 6.68 & 6.68 \\
\hline
\end{tabular}


Table 9: Additional Robustness Checks

\begin{tabular}{|c|c|c|c|c|c|c|c|c|}
\hline & \multicolumn{4}{|c|}{ Male Immigrants } & \multicolumn{4}{|c|}{ Female Immigrants } \\
\hline & \multicolumn{2}{|c|}{ OLS } & \multicolumn{2}{|c|}{ Reduced-Form } & \multicolumn{2}{|c|}{ OLS } & \multicolumn{2}{|c|}{ Reduced-Form } \\
\hline & (1) & (2) & (3) & (4) & (5) & (6) & (7) & (8) \\
\hline Immigrants from EU Member States & $\begin{array}{c}0.005 * * * \\
{[0.002]}\end{array}$ & $\begin{array}{c}0.005 * * * \\
{[0.002]}\end{array}$ & $\begin{array}{c}0.004 \\
{[0.003]}\end{array}$ & $\begin{array}{c}0.003 \\
{[0.006]}\end{array}$ & $\begin{array}{c}0.010^{* * * *} \\
{[0.002]}\end{array}$ & $\begin{array}{c}0.008^{* * *} \\
{[0.002]}\end{array}$ & $\begin{array}{c}0.020^{* * *} \\
{[0.003]}\end{array}$ & $\begin{array}{c}0.024^{* * *} \\
{[0.008]}\end{array}$ \\
\hline Immigrants from Outside the EU & $\begin{array}{c}0.008^{* * *} \\
{[0.001]}\end{array}$ & $\begin{array}{c}0.005^{* * *} \\
{[0.001]}\end{array}$ & $\begin{array}{c}0.015^{* * * *} \\
{[0.002]}\end{array}$ & $\begin{array}{c}0.002 \\
{[0.004]}\end{array}$ & $\begin{array}{c}0.008^{* * * *} \\
{[0.001]}\end{array}$ & $\begin{array}{c}0.002 \\
{[0.001]}\end{array}$ & $\begin{array}{c}0.023^{* * *} \\
{[0.002]}\end{array}$ & $\begin{array}{c}0.011^{* *} \\
{[0.005]}\end{array}$ \\
\hline Drop Immigrants with German Partners & $\begin{array}{c}0.002 \\
{[0.001]}\end{array}$ & $\begin{array}{c}-0.001 \\
{[0.001]}\end{array}$ & $\begin{array}{c}0.010^{* * * *} \\
{[0.002]}\end{array}$ & $\begin{array}{c}0.004 \\
{[0.004]}\end{array}$ & $\begin{array}{c}0.023^{* * * *} \\
{[0.001]}\end{array}$ & $\begin{array}{c}0.018^{* * *} \\
{[0.002]}\end{array}$ & $\begin{array}{c}0.025^{* * *} \\
{[0.002]}\end{array}$ & $\begin{array}{c}0.013^{* * * *} \\
{[0.005]}\end{array}$ \\
\hline Control for Children in Household & $\begin{array}{c}0.007^{* * *} \\
{[0.001]}\end{array}$ & $\begin{array}{c}0.005^{* * *} \\
{[0.001]}\end{array}$ & $\begin{array}{c}0.012^{* * *} \\
{[0.002]}\end{array}$ & $\begin{array}{c}0.004 \\
{[0.004]}\end{array}$ & $\begin{array}{c}0.008^{* * *} \\
{[0.001]}\end{array}$ & $\begin{array}{c}0.003^{* * *} \\
{[0.001]}\end{array}$ & $\begin{array}{c}0.020^{* * *} \\
{[0.002]}\end{array}$ & $\begin{array}{c}0.013^{* * *} \\
{[0.004]}\end{array}$ \\
\hline Drop Ex-Yugoslavia \& Middle East & $\begin{array}{c}0.006^{* * *} \\
{[0.001]}\end{array}$ & $\begin{array}{c}0.004^{* * *} \\
{[0.001]}\end{array}$ & $\begin{array}{c}0.011^{* * * *} \\
{[0.002]}\end{array}$ & $\begin{array}{c}-0.000 \\
{[0.004]}\end{array}$ & $\begin{array}{c}0.009 * * * \\
{[0.001]}\end{array}$ & $\begin{array}{c}0.006^{* * *} \\
{[0.001]}\end{array}$ & $\begin{array}{c}0.020^{* * *} \\
{[0.002]}\end{array}$ & $\begin{array}{c}0.018^{* * *} \\
{[0.005]}\end{array}$ \\
\hline Immigrants Arriving Prior to 1988 & $\begin{array}{l}0.004^{* *} \\
{[0.001]}\end{array}$ & $\begin{array}{c}0.003^{* *} \\
{[0.001]}\end{array}$ & $\begin{array}{l}-0.000 \\
{[0.003]}\end{array}$ & $\begin{array}{l}-0.004 \\
{[0.004]}\end{array}$ & $\begin{array}{c}0.005 * * * \\
{[0.002]}\end{array}$ & $\begin{array}{c}0.004^{* * *} \\
{[0.002]}\end{array}$ & $\begin{array}{c}0.011^{* * *} \\
{[0.004]}\end{array}$ & $\begin{array}{c}0.006 \\
{[0.005]}\end{array}$ \\
\hline Drop East German States & $\begin{array}{c}0.007^{* * *} \\
{[0.001]}\end{array}$ & $\begin{array}{c}0.004^{* * *} \\
{[0.001]}\end{array}$ & $\begin{array}{c}0.012^{* * * *} \\
{[0.002]}\end{array}$ & $\begin{array}{c}0.002 \\
{[0.004]}\end{array}$ & $\begin{array}{c}0.009^{* * * *} \\
{[0.001]}\end{array}$ & $\begin{array}{c}0.004^{* * *} \\
{[0.001]}\end{array}$ & $\begin{array}{c}0.023^{* * *} \\
{[0.002]}\end{array}$ & $\begin{array}{c}0.014^{* * *} \\
{[0.004]}\end{array}$ \\
\hline Add Economic Conditions & $\begin{array}{c}0.007^{* * *} \\
{[0.001]}\end{array}$ & $\begin{array}{c}0.005^{* * *} \\
{[0.001]}\end{array}$ & $\begin{array}{c}0.012^{* * *} \\
{[0.002]}\end{array}$ & $\begin{array}{c}0.003 \\
{[0.004]}\end{array}$ & $\begin{array}{c}0.009 * * * \\
{[0.001]}\end{array}$ & $\begin{array}{c}0.004^{* * *} \\
{[0.001]}\end{array}$ & $\begin{array}{c}0.022^{* * *} \\
{[0.002]}\end{array}$ & $\begin{array}{c}0.014^{* * *} \\
{[0.004]}\end{array}$ \\
\hline Use Flexible Age Dummies & $\begin{array}{c}0.006^{* * *} \\
{[0.001]}\end{array}$ & $\begin{array}{c}0.004^{* * *} \\
{[0.001]}\end{array}$ & $\begin{array}{c}0.011^{* * * *} \\
{[0.002]}\end{array}$ & $\begin{array}{c}0.003 \\
{[0.004]}\end{array}$ & $\begin{array}{c}0.008^{* * * *} \\
{[0.001]}\end{array}$ & $\begin{array}{c}0.004^{* * *} \\
{[0.001]}\end{array}$ & $\begin{array}{c}0.021^{* * *} \\
{[0.002]}\end{array}$ & $\begin{array}{c}0.013^{* * *} \\
{[0.004]}\end{array}$ \\
\hline Flexible Age, Year of Arrival Dummies & $\begin{array}{c}0.006^{* * *} \\
{[0.001]}\end{array}$ & $\begin{array}{c}0.004^{* * *} \\
{[0.001]}\end{array}$ & $\begin{array}{c}0.011^{* * *} \\
{[0.002]}\end{array}$ & $\begin{array}{c}0.003 \\
{[0.003]}\end{array}$ & $\begin{array}{c}0.008^{* * *} \\
{[0.001]}\end{array}$ & $\begin{array}{c}0.004^{* * *} \\
{[0.001]}\end{array}$ & $\begin{array}{c}0.021^{* * *} \\
{[0.002]}\end{array}$ & $\begin{array}{c}0.016^{* * *} \\
{[0.004]}\end{array}$ \\
\hline Individual Characteristics & Yes & Yes & Yes & Yes & Yes & Yes & Yes & Yes \\
\hline Years in Germany & No & Yes & No & Yes & No & Yes & No & Yes \\
\hline Region of Origin Fixed Effects & Yes & Yes & Yes & Yes & Yes & Yes & Yes & Yes \\
\hline Year Fixed Effects & Yes & Yes & Yes & Yes & Yes & Yes & Yes & Yes \\
\hline State Fixed Effects & Yes & Yes & Yes & Yes & Yes & Yes & Yes & Yes \\
\hline State-specific Linear Trends & Yes & Yes & Yes & Yes & Yes & Yes & Yes & Yes \\
\hline
\end{tabular}

Notes : The table reports OLS (columns (1)-(2) and (5)-(6)) and reduced-form estimates (columns (3)-(4) and (7)-(8)) where the dependent variable is log personal income adjusted to 2005 prices. The key independent variables are the number of years since a person got naturalized (in columns (1), (2), (5) and (6)) and the number of years since an individual became eligible for naturalization (in columns (3), (4), (7) and (8)). The first row drops immigrants who have a German spouse in 2007-09. The second row includes controls for the number and age structure of children in the household. The third row excludes all immigrants from Ex-Yugoslavia and the Middle East, the fourth one all immigrants who immigrated after 1988. The fifth row drops observations from East German states except Berlin, while the sixth row adds labor market controls (state unemployment rate (a linear and quadratic term) and the state GDP growth rate. The final two specifications include 5-year age dummies to control flexibly for age effects; the final specification further adds 5 year dummies for the arrival cohort to allow for general assimilation effects. All specifications include the same individual characteristics as in previous tables (education, age), state and year fixed effects, state-specific linear time trends and 10 region of origin fixed effects. The second specification (columns (2), (4), (6) and (8)) includes a linear and squared term of years spent in Germany (except for the last specification). Standard errors are clustered at the age $\mathrm{x}$ arrival cohort level. Statistical significance: ${ }^{* * *} p<0.01, * *$
$p<0.05, * p<0.1$. $\mathrm{p}<0.05, * \mathrm{p}<0.1$

Source: Microcensus (2007-2009). 
Figure 1: Number of Naturalizations in Germany

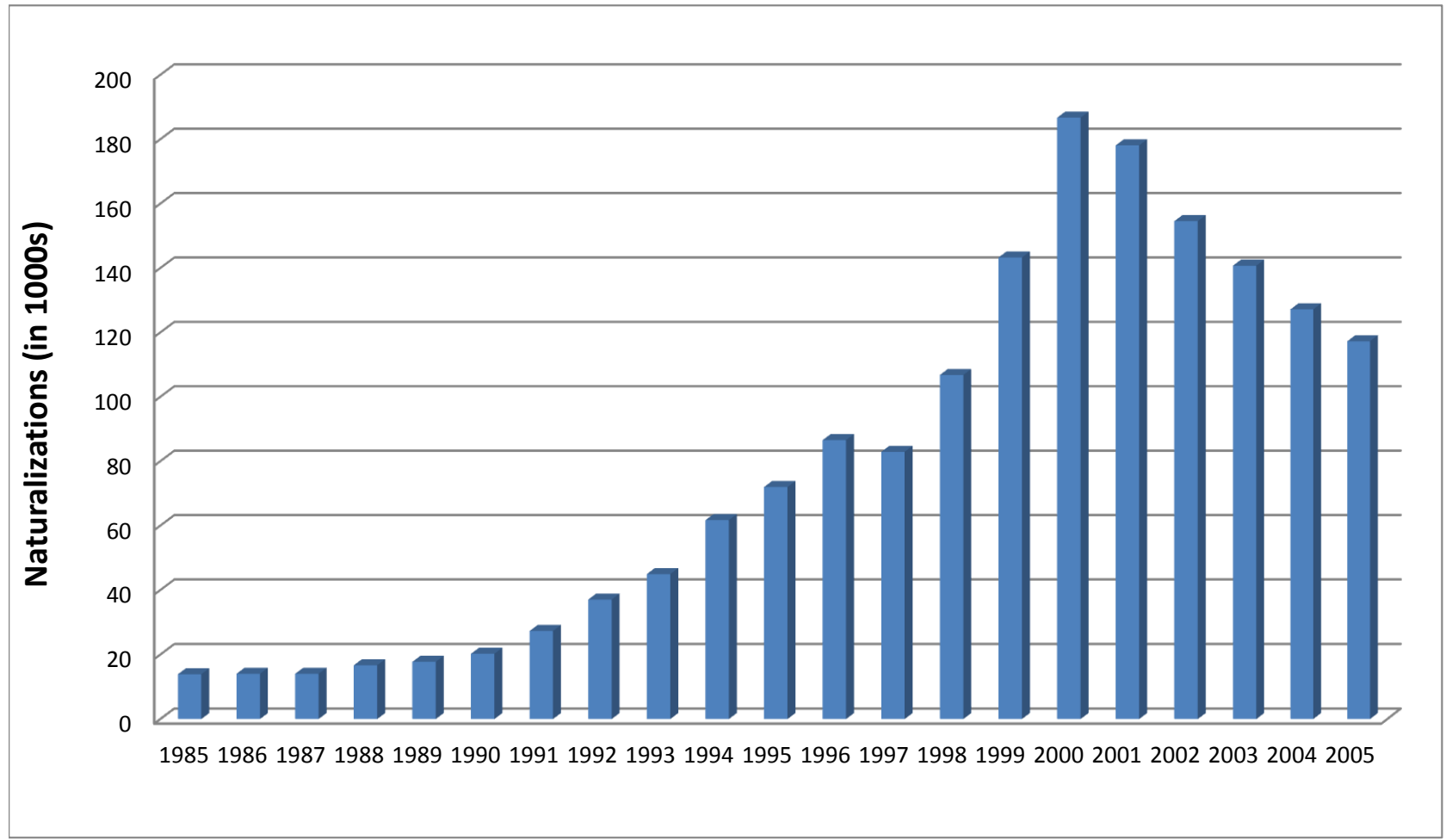

Notes: The figure reports official statistics of the number of naturalizations in Germany (excluding naturalized ethnic Germans). The figure contains discretionary naturalizations (applications for naturalization based on critera other than ancestry) prior to 1993; and naturalizations following the 1990 reform and other discretionary naturalizations after 1993. We exclude naturalizations through a legal claim (based on German ancestry prior to 1990) prior to 1993 and naturalizations based on German ancestry after 1993.

Source : Authors' calculations based on data of the Federal Statistical Office

Figure 2: Eligibility for German Citizenship after the 1991 and 2000 Reforms

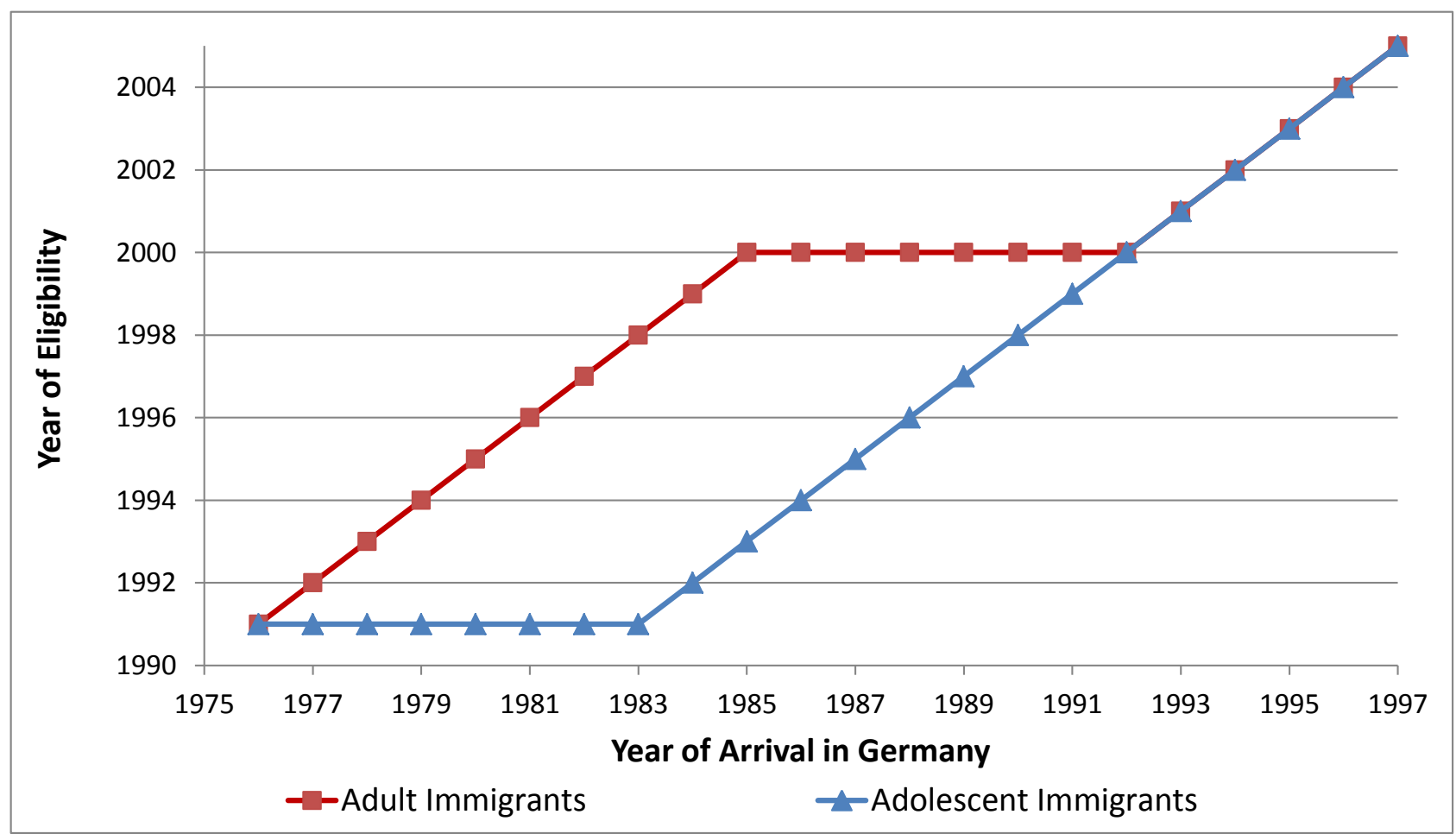

Notes: The figure shows the year of eligibility for naturalization as a function of the year of arrival and the residency requirement of the 1991 and 2000 reforms. Adolescent immigrants (aged 16-22) get eligible after 8 years of residency, while adult immigrants (aged 23 and older) faced a 15 -year residency requirement prior to 2000 and 8-year residency requirement after 2000.

Source : Authors' calculations. 


\begin{tabular}{|c|c|c|c|c|}
\hline & \multicolumn{2}{|c|}{ Male Immigrants } & \multicolumn{2}{|c|}{ Female Immigrants } \\
\hline & Mean & Std. Dev. & Mean & Std. Dev. \\
\hline Labor Force Participation & 0.752 & 0.432 & 0.550 & 0.498 \\
\hline Personal Income & 1411.50 & 945.63 & 831.79 & 729.32 \\
\hline Public Sector Employment & 0.046 & 0.210 & 0.114 & 0.319 \\
\hline White Collar Employment & 0.378 & 0.485 & 0.612 & 0.487 \\
\hline Self-Employed & 0.124 & 0.329 & 0.076 & 0.262 \\
\hline Permanent Work Contract & 0.834 & 0.372 & 0.815 & 0.389 \\
\hline Unemployment Benefits or Welfare Benefits & 0.154 & 0.361 & 0.114 & 0.318 \\
\hline Welfare Benefits & 0.777 & 0.417 & 0.865 & 0.342 \\
\hline Year of Arrival & 1990 & 6.808 & 1991 & 6.740 \\
\hline Years in Germany & 18.30 & 6.851 & 17.52 & 6.784 \\
\hline Naturalized & 0.374 & 0.484 & 0.363 & 0.481 \\
\hline Years since Naturalized & 3.83 & 6.485 & 3.85 & 6.620 \\
\hline Year 1st Eligible & 2000 & 4.850 & 2001 & 4.744 \\
\hline Years since Eligible & 7.73 & 4.909 & 7.16 & 4.807 \\
\hline Age & 33.350 & 8.281 & 33,200 & 7.806 \\
\hline Low-skilled & 0.469 & 0.499 & 0.512 & 0.500 \\
\hline Medium-skilled & 0.450 & 0.4974 & 0.390 & 0.297 \\
\hline High-skilled & 0.082 & 0.275 & 0.098 & 0.297 \\
\hline \multicolumn{5}{|l|}{ Region of origin } \\
\hline Traditional EU member states (EU 15) & 0.136 & 0.343 & 0.115 & 0.319 \\
\hline New EU Member States (EU 12) & 0.088 & 0.284 & 0.148 & 0.354 \\
\hline Ex-Yugoslavia & 0.128 & 0.335 & 0.117 & 0.321 \\
\hline Turkey & 0.311 & 0.463 & 0.290 & 0.454 \\
\hline Middle East & 0.090 & 0.287 & 0.065 & 0.245 \\
\hline Africa & 0.057 & 0.232 & 0.042 & 0.201 \\
\hline Asia & 0.051 & 0.220 & 0.066 & 0.249 \\
\hline North and South America & 0.017 & 0.131 & 0.028 & 0.166 \\
\hline Former Soviet Union (without EU12) & 0.101 & 0.302 & 0.115 & 0.319 \\
\hline Other or No Citizenship & 0.019 & 0.135 & 0.016 & 0.124 \\
\hline Source Country GDP per capita (in 1,000 ) & 9322.02 & 7597.63 & 13924.93 & 7149.25 \\
\hline Observations & 15,763 & & 16,609 & \\
\hline
\end{tabular}

Notes: The table shows summary statistics for the sample of first-generation immigrants who arrived in Germany between 1976 and 2000 and are 16-35 years old in the post-reform period (1991-2009). Ethnic Germans are excluded from the sample. The means for personal income, public sector and white collar employment are only available for the subsample of working individuals; GDP per capita in the country of origin (measured in 2005) is only available for immigrants for which we know the country of origin rather than only the region of origin. Low-skilled are those without highschool degree or vocational degree; medium-skilled individuals are those with a highschool or vocational degree; high-skilled are those with a college degree. 


\begin{tabular}{|c|c|c|c|c|}
\hline & \multicolumn{2}{|c|}{ Male Immigrants } & \multicolumn{2}{|c|}{ Female Immigrants } \\
\hline & Mean & Std. Dev. & Mean & Std. Dev. \\
\hline Labor force Participation & 0.783 & 0.412 & 0.481 & 0.500 \\
\hline Monthly Labor income & 2266.651 & 1483.377 & 1323.830 & 1030.752 \\
\hline Log Monthly Labor Income & 7.562 & 0.631 & 6.918 & 0.799 \\
\hline Speak German & 2.806 & 0.947 & 2.605 & 1.128 \\
\hline Write in German & 2.321 & 1.213 & 2.160 & 1.347 \\
\hline Year of Arrival & 1987 & 6 & 1987 & 6 \\
\hline Years in Germany & 11.982 & 6.880 & 11.867 & 6.937 \\
\hline Naturalized & 0.470 & 0.499 & 0.455 & 0.498 \\
\hline Years since Naturalized & 2.976 & 5.234 & 2.847 & 5.204 \\
\hline Eligible & 0.623 & 0.485 & 0.618 & 0.486 \\
\hline Years since Eligible & 3.635 & 4.472 & 3.662 & 4.520 \\
\hline Age & 31.69 & 9.12 & 31.69 & 9.12 \\
\hline Low-skilled & 0.440 & 0.496 & 0.440 & 0.496 \\
\hline Medium-skilled & 0.338 & 0.473 & 0.338 & 0.473 \\
\hline High-skilled & 0.110 & 0.313 & 0.110 & 0.313 \\
\hline In School & 0.111 & 0.315 & 0.111 & 0.315 \\
\hline \multicolumn{5}{|l|}{ Region of origin } \\
\hline$\overline{\text { Traditional EU Member Countries (EU 15) }}$ & 0.123 & 0.329 & 0.139 & 0.346 \\
\hline New EU Member Countries (EU 12) & 0.207 & 0.405 & 0.239 & 0.426 \\
\hline Ex-Yugoslavia & 0.084 & 0.277 & 0.077 & 0.267 \\
\hline Turkey & 0.299 & 0.458 & 0.270 & 0.444 \\
\hline Middle East & 0.023 & 0.150 & 0.015 & 0.120 \\
\hline Africa & 0.012 & 0.109 & 0.006 & 0.077 \\
\hline Asia & 0.015 & 0.122 & 0.018 & 0.134 \\
\hline North and South America & 0.017 & 0.130 & 0.017 & 0.131 \\
\hline Former Soviet Union (without EU 12) & 0.217 & 0.412 & 0.216 & 0.411 \\
\hline Other or no Citizenship & 0.003 & 0.050 & 0.003 & 0.057 \\
\hline Observations & 9,642 & & 10,601 & \\
\hline
\end{tabular}

Notes : The table reports summary statistics for first-generation immigrants who are not ethnic Germans, arrived in Germany between 1976 and 2000 and who are 16-35 years old in the post-reform period (1991-2009). Writing and speaking German are self-assessed language abilities which vary from 0 (not at all) to 4 (very well). Naturalized is equal to one if a person is actually naturalized. Eligible is equal to one if an individual is (a) aged 16-22, has lived in Germany for at least 8 years and the year is 1991 or later; (b) aged 23-35, has lived in Germany for at least 15 years in the period 1991-1999; or (c) aged 23-35, has lived in Germany for at least 8 years and the year is 2000 or later. Low-skilled individuals are those without a highschool degree or vocational degree; medium-skilled are those with highschool degree or vocational degree; high-skilled are those with college degree. Individuals are in school if they still attend school over the past four weeks.

Source : Socio-Economic Panel (1984-2009) 


\begin{tabular}{|c|c|c|c|c|c|c|}
\hline & \multicolumn{3}{|c|}{$\begin{array}{c}\text { Male Immigrants } \\
\text { Exit from Population } \\
\text { (Emigration or Mortality) }\end{array}$} & \multicolumn{3}{|c|}{$\begin{array}{c}\text { Female Immigrants } \\
\text { Exit from Population } \\
\text { (Emigration or Mortality) }\end{array}$} \\
\hline & $(1)$ & $(2)$ & $(3)$ & $(4)$ & (5) & $(6)$ \\
\hline Eventually Naturalized & $\begin{array}{c}-0.010^{* * *} \\
{[0.003]}\end{array}$ & & & $\begin{array}{c}-0.008^{* * *} \\
{[0.002]}\end{array}$ & & \\
\hline Actually Naturalized & & $\begin{array}{c}-0.001 \\
{[0.004]}\end{array}$ & & & $\begin{array}{c}-0.001 \\
{[0.003]}\end{array}$ & \\
\hline Eligible for Naturalization & & & $\begin{array}{c}-0.004 \\
{[0.005]}\end{array}$ & & & $\begin{array}{c}-0.003 \\
{[0.004]}\end{array}$ \\
\hline Years in Germany & $\begin{array}{c}-0.004^{* * *} \\
{[0.001]}\end{array}$ & $\begin{array}{c}-0.004 * * * \\
{[0.001]}\end{array}$ & $\begin{array}{c}-0.003 * * * \\
{[0.001]}\end{array}$ & $\begin{array}{c}-0.002 * * \\
{[0.001]}\end{array}$ & $\begin{array}{c}-0.002^{* *} \\
{[0.001]}\end{array}$ & $\begin{array}{c}-0.001 \\
{[0.001]}\end{array}$ \\
\hline Years in Germany Squared & $\begin{array}{c}0.000 * * * \\
{[0.000]}\end{array}$ & $\begin{array}{c}0.000 * * * \\
{[0.000]}\end{array}$ & $\begin{array}{c}0.000 * * \\
{[0.000]}\end{array}$ & $\begin{array}{l}0.000 * \\
{[0.000]}\end{array}$ & $\begin{array}{l}0.000 * \\
{[0.000]}\end{array}$ & $\begin{array}{c}0.000 \\
{[0.000]}\end{array}$ \\
\hline Age & $\begin{array}{l}0.002^{*} \\
{[0.001]}\end{array}$ & $\begin{array}{l}0.002 * \\
{[0.001]}\end{array}$ & $\begin{array}{c}-0.003 * * * \\
{[0.001]}\end{array}$ & $\begin{array}{c}-0.001 \\
{[0.001]}\end{array}$ & $\begin{array}{c}-0.001 \\
{[0.001]}\end{array}$ & $\begin{array}{c}-0.001 \\
{[0.001]}\end{array}$ \\
\hline Age Squared & $\begin{array}{l}-0.000 * \\
{[0.000]}\end{array}$ & $\begin{array}{l}-0.000 * \\
{[0.000]}\end{array}$ & $\begin{array}{c}0.000 * * \\
{[0.000]}\end{array}$ & $\begin{array}{c}0.000 \\
{[0.000]}\end{array}$ & $\begin{array}{c}0.000 \\
{[0.000]}\end{array}$ & $\begin{array}{c}0.000 \\
{[0.000]}\end{array}$ \\
\hline Medium-skilled & $\begin{array}{c}-0.003 \\
{[0.003]}\end{array}$ & $\begin{array}{c}-0.003 \\
{[0.003]}\end{array}$ & $\begin{array}{c}0.002 \\
{[0.001]}\end{array}$ & $\begin{array}{c}-0.009 * * * \\
{[0.003]}\end{array}$ & $\begin{array}{c}-0.010 * * * \\
{[0.003]}\end{array}$ & $\begin{array}{c}-0.010^{* * *} \\
{[0.003]}\end{array}$ \\
\hline High-skilled & $\begin{array}{c}-0.002 \\
{[0.006]}\end{array}$ & $\begin{array}{c}-0.003 \\
{[0.006]}\end{array}$ & $\begin{array}{c}-0.000 \\
{[0.000]}\end{array}$ & $\begin{array}{c}0.004 \\
{[0.005]}\end{array}$ & $\begin{array}{c}0.004 \\
{[0.005]}\end{array}$ & $\begin{array}{c}0.004 \\
{[0.005]}\end{array}$ \\
\hline In School & $\begin{array}{c}0.008 \\
{[0.007]}\end{array}$ & $\begin{array}{c}0.007 \\
{[0.007]}\end{array}$ & $\begin{array}{c}-0.003 \\
{[0.003]}\end{array}$ & $\begin{array}{c}-0.004 \\
{[0.005]}\end{array}$ & $\begin{array}{c}-0.004 \\
{[0.005]}\end{array}$ & $\begin{array}{c}-0.004 \\
{[0.005]}\end{array}$ \\
\hline Year Fixed Effects & Yes & Yes & Yes & Yes & Yes & Yes \\
\hline State Fixed Effects & Yes & Yes & Yes & Yes & Yes & Yes \\
\hline State-specific Linear Trends & Yes & Yes & Yes & Yes & Yes & Yes \\
\hline Region of Origin Fixed Effects & Yes & Yes & Yes & Yes & Yes & Yes \\
\hline Observations & 9,255 & 9,255 & 9,255 & 10,116 & 10,116 & 10,116 \\
\hline R Squared & 0.029 & 0.028 & 0.028 & 0.032 & 0.031 & 0.031 \\
\hline
\end{tabular}

Notes : The table reports OLS estimates of the probability that an immigrant exits from the population (either through mortality or moving abroad) in the GSOEP. The key independent variables are whether an immigrant eventually naturalizes while participating in the GSOEP (columns (1) and (4)); whether the immigrant is currently naturalized (columns (2) and (5)); or whether the immigrant is currently eligible for naturalization (columns ( 3 ) and (6)). The sample is defined as in Table 1 . All control variables are the same as in previous tables. Statistical significance: $* * * p<0.01, * *$ p $<0.05$ and $*$ $\mathrm{p}<0.1$.

Source : Socio-Economic Panel (1984-2009) 
Table A4: The Propensity to Naturalize using Alternative Specifications

\begin{tabular}{|c|c|c|c|c|c|c|c|c|}
\hline & \multicolumn{4}{|c|}{ Male Immigrants } & \multicolumn{4}{|c|}{ Female Immigrants } \\
\hline & \multicolumn{2}{|c|}{ Probit Estimates } & \multicolumn{2}{|c|}{ Lagged Eligibility } & \multicolumn{2}{|c|}{ Probit Estimates } & \multicolumn{2}{|c|}{ Lagged Eligibility } \\
\hline & $\begin{array}{c}\text { Base } \\
(1) \\
\end{array}$ & $\begin{array}{c}\text { Years in G } \\
(2) \\
\end{array}$ & $\begin{array}{c}\text { Base } \\
(3) \\
\end{array}$ & $\begin{array}{c}\text { Years in G } \\
(4) \\
\end{array}$ & $\begin{array}{c}\text { Base } \\
(5) \\
\end{array}$ & $\begin{array}{c}\text { Years in G } \\
(6) \\
\end{array}$ & $\begin{array}{c}\text { Base } \\
(7) \\
\end{array}$ & $\begin{array}{c}\text { Years in G } \\
(8) \\
\end{array}$ \\
\hline Eligible for Naturalization & $\begin{array}{c}0.142^{* * *} \\
{[0.018]}\end{array}$ & $\begin{array}{c}0.041 * \\
{[0.023]}\end{array}$ & $\begin{array}{c}0.061 * * * \\
{[0.010]}\end{array}$ & $\begin{array}{c}0.017 \\
{[0.011]}\end{array}$ & $\begin{array}{c}0.240 * * * \\
{[0.015]}\end{array}$ & $\begin{array}{c}0.044 * * \\
{[0.022]}\end{array}$ & $\begin{array}{c}0.138 * * * \\
{[0.011]}\end{array}$ & $\begin{array}{c}0.058^{* * *} \\
{[0.011]}\end{array}$ \\
\hline Years in Germany & & $\begin{array}{c}0.030 * * * \\
{[0.006]}\end{array}$ & & $\begin{array}{c}0.006^{* * *} \\
{[0.002]}\end{array}$ & & $\begin{array}{c}0.049 * * * \\
{[0.005]}\end{array}$ & & $\begin{array}{c}0.012 * * * \\
{[0.002]}\end{array}$ \\
\hline Years in Germany Squared & & $\begin{array}{c}-0.000 * * * \\
{[0.000]}\end{array}$ & & $\begin{array}{c}-0.000 \\
{[0.000]}\end{array}$ & & $\begin{array}{c}-0.001 * * * \\
{[0.000]}\end{array}$ & & $\begin{array}{c}-0.000 \\
{[0.000]}\end{array}$ \\
\hline Age & $\begin{array}{c}-0.002 \\
{[0.007]}\end{array}$ & $\begin{array}{c}-0.000 \\
{[0.007]}\end{array}$ & $\begin{array}{c}-0.000 \\
{[0.003]}\end{array}$ & $\begin{array}{c}-0.000 \\
{[0.003]}\end{array}$ & $\begin{array}{c}-0.019 * * * \\
{[0.007]}\end{array}$ & $\begin{array}{c}-0.020 * * * \\
{[0.007]}\end{array}$ & $\begin{array}{c}-0.008^{* *} \\
{[0.003]}\end{array}$ & $\begin{array}{c}-0.010 * * * \\
{[0.003]}\end{array}$ \\
\hline Age Squared & $\begin{array}{c}0.000 \\
{[0.000]}\end{array}$ & $\begin{array}{c}-0.000 \\
{[0.000]}\end{array}$ & $\begin{array}{c}0.000 \\
{[0.000]}\end{array}$ & $\begin{array}{c}0.000 \\
{[0.000]}\end{array}$ & $\begin{array}{c}0.000 * * * \\
{[0.000]}\end{array}$ & $\begin{array}{c}0.000 * * \\
{[0.000]}\end{array}$ & $\begin{array}{c}0.000 * * * \\
{[0.000]}\end{array}$ & $\begin{array}{c}0.000 * * * \\
{[0.000]}\end{array}$ \\
\hline Medium-skilled & $\begin{array}{c}0.091 * * * \\
{[0.016]}\end{array}$ & $\begin{array}{c}0.085^{* * *} \\
{[0.016]}\end{array}$ & $\begin{array}{c}0.036 * * * \\
{[0.006]}\end{array}$ & $\begin{array}{c}0.036^{* * *} \\
{[0.006]}\end{array}$ & $\begin{array}{c}0.086 * * * \\
{[0.015]}\end{array}$ & $\begin{array}{c}0.080 * * * \\
{[0.014]}\end{array}$ & $\begin{array}{c}0.037 * * * \\
{[0.007]}\end{array}$ & $\begin{array}{c}0.037^{* * *} \\
{[0.007]}\end{array}$ \\
\hline High-skilled & $\begin{array}{l}0.050 * \\
{[0.027]}\end{array}$ & $\begin{array}{c}0.074 * * * \\
{[0.028]}\end{array}$ & $\begin{array}{c}0.011 \\
{[0.014]}\end{array}$ & $\begin{array}{c}0.020 \\
{[0.014]}\end{array}$ & $\begin{array}{c}-0.086 * * * \\
{[0.021]}\end{array}$ & $\begin{array}{c}-0.066 * * * \\
{[0.022]}\end{array}$ & $\begin{array}{c}-0.057 * * * \\
{[0.015]}\end{array}$ & $\begin{array}{c}-0.042 * * * \\
{[0.015]}\end{array}$ \\
\hline In School & $\begin{array}{c}0.130 * * * \\
{[0.032]}\end{array}$ & $\begin{array}{c}0.133^{* * *} \\
{[0.032]}\end{array}$ & $\begin{array}{c}0.052 * * * \\
{[0.012]}\end{array}$ & $\begin{array}{c}0.049 * * * \\
{[0.012]}\end{array}$ & $\begin{array}{c}0.133 * * * \\
{[0.029]}\end{array}$ & $\begin{array}{c}0.104^{* * *} \\
{[0.031]}\end{array}$ & $\begin{array}{c}0.068 * * * \\
{[0.012]}\end{array}$ & $\begin{array}{c}0.056 * * * \\
{[0.013]}\end{array}$ \\
\hline Region of Origin Fixed Effects & Yes & Yes & Yes & Yes & Yes & Yes & Yes & Yes \\
\hline Year Fixed Effects & Yes & Yes & Yes & Yes & Yes & Yes & Yes & Yes \\
\hline State Fixed Effects & Yes & Yes & Yes & Yes & Yes & Yes & Yes & Yes \\
\hline State-specific Linear Trends & Yes & Yes & Yes & Yes & Yes & Yes & Yes & Yes \\
\hline Individual Fixed Effects & No & No & No & No & No & No & No & No \\
\hline Observations & 9,641 & 9,641 & 9,462 & 9,462 & 10,274 & 10,274 & 10,383 & 10,383 \\
\hline Log-likelihood & -2434.04 & -2394.06 & & & -3099.03 & -2959.13 & & \\
\hline R Squared & 0.627 & 0.633 & 0.680 & 0.683 & 0.556 & 0.576 & 0.621 & 0.629 \\
\hline
\end{tabular}

Notes: The dependent variable is a binary indicator equal to one if a first-generation migrant has naturalized and zero otherwise. The sample includes all migrants who are not ethnic Germans, arrived in Germany between 1976 to 2000, are 16-35 years old in some year in the 1991-2009 period, and report valid information on income, naturalization and years lived in Germany. The eligibility indicator is equal to one if an individual is either: a) $16-22$ years old and has lived in Germany for at least 8 years; or b) is $23-35$ years old and has lived in Germany for at least 15 years in the 1991-1999 period; and c) is 23-35 years old and has lived in Germany for at least 8 years after 2000. The left-hand side reports results for men, the right-hand side for women. All specifications also include state and year fixed effects, state-specific linear trends and 10 region of origin fixed effects (traditional EU countries, new EU entrants (EU12), ex-Yugoslavia, Turkey, Middle East, Asia, Africa, North and South America, Russia and other former Soviet Union republics, other or no passport). The first specification (columns (1)-(2) and (5)-(6)) report marginal effects from a probit model. The second specification (columns (3)-(4) and (7)-(8)) use lagged eligibility rather than current eligiblity as key independent variable. The omitted education category is low-skilled (no high school or vocational degree). Standard errors in brackets are clustered at the age $\mathrm{x}$ arrival cohort level. Statistical significance. ${ }^{* * *} p<0.01,{ }^{* *} p<0.05,{ }^{*} p<0.1$. See also notes to Table 1 .

Source : Socio-Economic Panel (1984-2009) 
Table A5: The Propensity to Naturalize after the 1991 and 2000 Reforms

\begin{tabular}{|c|c|c|c|c|c|c|}
\hline & \multicolumn{3}{|c|}{ Male Immigrants } & \multicolumn{3}{|c|}{ Female Immigrants } \\
\hline & $\begin{array}{c}\text { Base } \\
(1) \\
\end{array}$ & $\begin{array}{c}\text { Years in G } \\
\text { (2) }\end{array}$ & $\begin{array}{c}\text { Hetero } \\
(3)\end{array}$ & $\begin{array}{c}\text { Base } \\
(4)\end{array}$ & $\begin{array}{c}\text { Years in G } \\
(5)\end{array}$ & $\begin{array}{c}\text { Hetero } \\
(6)\end{array}$ \\
\hline Eligible for Naturalization & $\begin{array}{c}0.045 * * * \\
{[0.007]}\end{array}$ & $\begin{array}{c}0.030 * * * \\
{[0.007]}\end{array}$ & $\begin{array}{c}-0.094^{* * *} \\
{[0.033]}\end{array}$ & $\begin{array}{c}0.056 * * * \\
{[0.007]}\end{array}$ & $\begin{array}{c}0.044 * * * \\
{[0.008]}\end{array}$ & $\begin{array}{c}-0.027 \\
{[0.050]}\end{array}$ \\
\hline Eligible*new EU12 & & & $\begin{array}{l}-0.024 \\
{[0.041]}\end{array}$ & & & $\begin{array}{l}-0.018 \\
{[0.054]}\end{array}$ \\
\hline Eligible*Ex-Yugoslavia & & & $\begin{array}{c}0.173^{* * *} \\
{[0.040]}\end{array}$ & & & $\begin{array}{l}0.092^{*} \\
{[0.055]}\end{array}$ \\
\hline Eligible*Turkey & & & $\begin{array}{c}0.099 * * * \\
{[0.034]}\end{array}$ & & & $\begin{array}{c}0.049 \\
{[0.051]}\end{array}$ \\
\hline Eligible*Middle East & & & $\begin{array}{c}0.177^{* * *} \\
{[0.037]}\end{array}$ & & & $\begin{array}{c}0.178^{* * *} \\
{[0.055]}\end{array}$ \\
\hline Eligible*Africa & & & $\begin{array}{c}0.145^{* * *} \\
{[0.039]}\end{array}$ & & & $\begin{array}{c}0.079 \\
{[0.055]}\end{array}$ \\
\hline Eligible*Asia & & & $\begin{array}{c}0.187^{* * *} \\
{[0.043]}\end{array}$ & & & $\begin{array}{c}0.120^{* *} \\
{[0.057]}\end{array}$ \\
\hline Eligible*(North and South America) & & & $\begin{array}{c}0.075 \\
{[0.068]}\end{array}$ & & & $\begin{array}{c}0.068 \\
{[0.066]}\end{array}$ \\
\hline Eligible*(Russia and Former SU) & & & $\begin{array}{l}0.087^{*} \\
{[0.051]}\end{array}$ & & & $\begin{array}{c}0.037 \\
{[0.061]}\end{array}$ \\
\hline Eligible*(Other or No Passport) & & & $\begin{array}{c}0.288^{* * *} \\
{[0.074]}\end{array}$ & & & $\begin{array}{c}0.102 \\
{[0.079]}\end{array}$ \\
\hline Years in Germany & & $\begin{array}{c}-0.023 * * * \\
{[0.001]}\end{array}$ & $\begin{array}{c}-0.023^{* * *} \\
{[0.001]}\end{array}$ & & $\begin{array}{c}-0.022^{* * *} \\
{[0.001]}\end{array}$ & $\begin{array}{c}-0.022^{* * *} \\
{[0.001]}\end{array}$ \\
\hline Years in Germany Squared & & $\begin{array}{c}0.002 * * * \\
{[0.000]}\end{array}$ & $\begin{array}{c}0.002 * * * \\
{[0.000]}\end{array}$ & & $\begin{array}{c}0.001 * * * \\
{[0.000]}\end{array}$ & $\begin{array}{c}0.001^{* * *} \\
{[0.000]}\end{array}$ \\
\hline Age & $\begin{array}{c}-0.009 * * * \\
{[0.001]}\end{array}$ & $\begin{array}{c}-0.007 * * * \\
{[0.001]}\end{array}$ & $\begin{array}{c}-0.007^{* * *} \\
{[0.001]}\end{array}$ & $\begin{array}{c}-0.009 * * * \\
{[0.001]}\end{array}$ & $\begin{array}{c}-0.008^{* * *} \\
{[0.001]}\end{array}$ & $\begin{array}{c}-0.008^{* * *} \\
{[0.001]}\end{array}$ \\
\hline Age Squared & $\begin{array}{c}0.000^{* * *} \\
{[0.000]}\end{array}$ & $\begin{array}{c}0.000 * * * \\
{[0.000]}\end{array}$ & $\begin{array}{c}0.000 * * * \\
{[0.000]}\end{array}$ & $\begin{array}{c}0.000^{* * *} \\
{[0.000]}\end{array}$ & $\begin{array}{c}0.000 * * * \\
{[0.000]}\end{array}$ & $\begin{array}{c}0.000 * * * \\
{[0.000]}\end{array}$ \\
\hline Medium-skilled & $\begin{array}{c}0.013 * * * \\
{[0.003]}\end{array}$ & $\begin{array}{c}0.014 * * * \\
{[0.003]}\end{array}$ & $\begin{array}{c}0.014 * * * \\
{[0.003]}\end{array}$ & $\begin{array}{c}-0.004 \\
{[0.003]}\end{array}$ & $\begin{array}{c}-0.002 \\
{[0.003]}\end{array}$ & $\begin{array}{c}-0.002 \\
{[0.003]}\end{array}$ \\
\hline High-skilled & $\begin{array}{c}-0.026 * * * \\
{[0.005]}\end{array}$ & $\begin{array}{c}-0.025^{* * *} \\
{[0.005]}\end{array}$ & $\begin{array}{c}-0.024 * * * \\
{[0.005]}\end{array}$ & $\begin{array}{c}-0.054 * * * \\
{[0.006]}\end{array}$ & $\begin{array}{c}-0.052^{* * *} \\
{[0.006]}\end{array}$ & $\begin{array}{c}-0.052^{* * *} \\
{[0.006]}\end{array}$ \\
\hline Region of Origin Fixed Effects & Yes & Yes & Yes & Yes & Yes & Yes \\
\hline Year Fixed Effects & Yes & Yes & Yes & Yes & Yes & Yes \\
\hline State Fixed Effects & Yes & Yes & Yes & Yes & Yes & Yes \\
\hline State-specific Linear Trends & Yes & Yes & Yes & Yes & Yes & Yes \\
\hline Individual Fixed Effects & No & No & No & No & No & No \\
\hline Observations & 38,206 & 38,206 & 38,206 & 38,155 & 38,155 & 38,155 \\
\hline R Squared & 0.104 & 0.113 & 0.116 & 0.093 & 0.101 & 0.103 \\
\hline Mean of Dependent Variable & 0.11 & 0.11 & 0.11 & 0.12 & 0.12 & 0.12 \\
\hline
\end{tabular}

Notes: The table reports results from a linear probability model where the dependent variable is a binary indicator equal to one if a migrant has naturalized in a given year and zero otherwise. The sample includes all first-generation immigrants who are not ethnic Germans, arrived in Germany between 1976 to 2000, are 16-35 years old in some year in the 1991-2009 period, and report valid information on income, naturalization and years lived in Germany. The eligibility indicator is equal to one if an individual is a) 16-22 years old and has lived in Germany for at least 8 years; b) 23-35 years old and has lived in Germany for at least 15 years in 1991-1999; or c) 23-35 years old and has lived in Germany for at least 8 years after 2000. The left-hand side reports results for male immigrants, the right-hand side for female immigrants. The second specification adds a linear and squared term of years in Germany; and the third specification allows for heterogeneous effects by region of origin. All specifications include state and year fixed effects as well as statespecific linear trends. We also include 10 region of origin fixed effects (traditional EU countries, new EU entrants (EU-12), ex-Yugoslavia, Turkey, Middle East, Asia, Africa, North and South America, Russia and other former Soviet Union republics, other or no citizenship). The omitted region of origin are the original EU-15 member states; the omitted education category is low-skilled (no high school or vocational degree). Standard errors are clustered at the age $\mathrm{x}$ arrival cohort level. Statistical significance: ${ }^{* * *} \mathrm{p}<0.01,{ }^{* *} \mathrm{p}<0.05,{ }^{*} \mathrm{p}<0.1$.

Source : Microcensus Pseudopanel (1985-2009). 
Table A6: The Propensity to Naturalize For Different Immigration Waves

\begin{tabular}{|c|c|c|c|c|c|c|c|c|c|c|c|c|}
\hline & \multicolumn{6}{|c|}{ Male Immigrants } & \multicolumn{6}{|c|}{ Female Immigrants } \\
\hline & \multicolumn{3}{|c|}{$\frac{\text { Guest Worker Immigrants }}{\underline{\text { (arrived 1976-1989) }}}$} & \multicolumn{3}{|c|}{$\frac{\text { Recent Immigrants }}{\text { (arrived 1990-2000) }}$} & \multicolumn{3}{|c|}{$\frac{\text { Guest Worker Immigrants }}{\text { (arrived 1976-1989) }}$} & \multicolumn{3}{|c|}{$\begin{array}{l}\text { Recent Immigrants } \\
\text { (arrived 1990-2000) }\end{array}$} \\
\hline & (1) & (2) & (3) & (4) & (5) & (6) & (7) & (8) & (9) & (10) & (11) & (12) \\
\hline Eligible for Naturalization & $\begin{array}{c}0.019^{* * *} \\
{[0.007]}\end{array}$ & $\begin{array}{c}-0.004 \\
0.0071\end{array}$ & $\begin{array}{l}-0.104^{* * *} \\
{[0.039]}\end{array}$ & $\begin{array}{l}0.075^{* * *} \\
{[0.013]}\end{array}$ & $0.035^{* *}$ & $\begin{array}{l}-0.145^{* * *} \\
{[0.043]}\end{array}$ & $\begin{array}{c}0.032^{* * *} \\
{[0.008]}\end{array}$ & $\begin{array}{c}0.012 \\
{[0.008]}\end{array}$ & $\begin{array}{r}-0.010 \\
{[0.068]}\end{array}$ & $\begin{array}{l}0.076^{* * *} \\
{[0.013]}\end{array}$ & $\begin{array}{c}0.050^{* * *} \\
{[0.014]}\end{array}$ & $\begin{array}{c}-0.127^{* *} \\
{[0.051]}\end{array}$ \\
\hline Eligible*new EU12 & & & $\begin{array}{c}-0.110^{* *} \\
{[0.043]}\end{array}$ & & & $\begin{array}{c}0.027 \\
{[0.061]}\end{array}$ & & & $\begin{array}{c}-0.114 \\
{[0.074]}\end{array}$ & & & $\begin{array}{c}0.080 \\
{[0.057]}\end{array}$ \\
\hline Eligible*Ex-Yugoslavia & & & $\begin{array}{l}0.087^{*} \\
{[0.048]}\end{array}$ & & & $\begin{array}{c}0.232^{* * *} \\
{[0.052]}\end{array}$ & & & $\begin{array}{c}0.007 \\
{[0.072]}\end{array}$ & & & $\begin{array}{c}0.176^{* * *} \\
{[0.059]}\end{array}$ \\
\hline Eligible*Turkey & & & $\begin{array}{l}0.096 * * \\
{[0.039]}\end{array}$ & & & $\begin{array}{c}0.195 * * * \\
{[0.049]}\end{array}$ & & & $\begin{array}{c}0.010 \\
{[0.068]}\end{array}$ & & & $\begin{array}{c}0.218^{* * *} \\
{[0.057]}\end{array}$ \\
\hline Eligible*Middle East & & & $\begin{array}{c}0.163 * * * \\
{[0.045]}\end{array}$ & & & $\begin{array}{c}0.185^{* * *} \\
{[0.049]}\end{array}$ & & & $\begin{array}{c}0.110 \\
{[0.073]}\end{array}$ & & & $\begin{array}{c}0.273^{* * *} \\
{[0.060]}\end{array}$ \\
\hline Eligible*Africa & & & $\begin{array}{c}0.131^{* * *} \\
{[0.047]}\end{array}$ & & & $\begin{array}{c}0.165 * * * \\
{[0.052]}\end{array}$ & & & $\begin{array}{c}0.047 \\
{[0.073]}\end{array}$ & & & $\begin{array}{c}0.172^{* * *} \\
{[0.065]}\end{array}$ \\
\hline Eligible*Asia & & & $\begin{array}{c}0.150^{* * *} \\
{[0.050]}\end{array}$ & & & $\begin{array}{c}0.270 * * * \\
{[0.063]}\end{array}$ & & & $\begin{array}{c}0.067 \\
{[0.076]}\end{array}$ & & & $\begin{array}{c}0.217^{* * *} \\
{[0.062]}\end{array}$ \\
\hline Eligible*(North and South America) & & & $\begin{array}{c}-0.025 \\
{[0.081]}\end{array}$ & & & $\begin{array}{l}0.189^{*} \\
{[0.100]}\end{array}$ & & & $\begin{array}{c}0.003 \\
{[0.102]}\end{array}$ & & & $\begin{array}{l}0.167 * * \\
{[0.071]}\end{array}$ \\
\hline Eligible*(Russia and Former SU) & & & $\begin{array}{c}-0.017 \\
{[0.128]}\end{array}$ & & & $\begin{array}{l}0.128^{* *} \\
{[0.058]}\end{array}$ & & & $\begin{array}{c}0.052 \\
{[0.134]}\end{array}$ & & & $\begin{array}{l}0.129 * * \\
{[0.061]}\end{array}$ \\
\hline Eligible*(Other/No Citizenship) & & & $\begin{array}{l}0.222 * * \\
{[0.089]}\end{array}$ & & & $\begin{array}{c}0.345^{* * *} \\
{[0.104]}\end{array}$ & & & $\begin{array}{c}0.133 \\
{[0.113]}\end{array}$ & & & $\begin{array}{c}0.099 \\
{[0.082]}\end{array}$ \\
\hline Years in Germany & & $\begin{array}{l}-0.019 * * * \\
{[0.002]}\end{array}$ & $\begin{array}{l}-0.019 * * * \\
{[0.002]}\end{array}$ & & $\begin{array}{l}-0.046^{* * *} \\
{[0.004]}\end{array}$ & $\begin{array}{c}-0.046^{* * *} \\
{[0.004]}\end{array}$ & & $\begin{array}{l}-0.018^{* * *} \\
{[0.002]}\end{array}$ & $\begin{array}{l}-0.018^{* * *} \\
{[0.002]}\end{array}$ & & $\begin{array}{c}-0.041^{* * *} \\
{[0.003]}\end{array}$ & $\begin{array}{c}-0.041^{* * *} \\
{[0.003]}\end{array}$ \\
\hline Years in Germany Squared & & $\begin{array}{c}0.001 * * * \\
{[0.000]}\end{array}$ & $\begin{array}{c}0.001 * * * \\
{[0.000]}\end{array}$ & & $\begin{array}{l}0.005 * * * \\
{[0.000]}\end{array}$ & $\begin{array}{c}0.005^{* * *} \\
{[0.000]}\end{array}$ & & $\begin{array}{c}0.001^{* * *} \\
{[0.000]}\end{array}$ & $\begin{array}{c}0.001 * * * \\
{[0.000]}\end{array}$ & & $\begin{array}{c}0.004^{* * *} \\
{[0.000]}\end{array}$ & $\begin{array}{c}0.004^{* * *} \\
{[0.000]}\end{array}$ \\
\hline Age & $\begin{array}{c}-0.011^{* * *} \\
{[0.001]}\end{array}$ & $\begin{array}{c}-0.008^{* * *} \\
{[0.001]}\end{array}$ & $\begin{array}{c}-0.007 * * * \\
{[0.001]}\end{array}$ & $\begin{array}{c}-0.005 * * * \\
{[0.001]}\end{array}$ & $\begin{array}{c}-0.007 * * * \\
{[0.001]}\end{array}$ & $\begin{array}{c}-0.007 * * * \\
{[0.001]}\end{array}$ & $\begin{array}{c}-0.010^{* * *} \\
{[0.001]}\end{array}$ & $\begin{array}{c}-0.007^{* * *} \\
{[0.001]}\end{array}$ & $\begin{array}{c}-0.007 * * * \\
{[0.001]}\end{array}$ & $\begin{array}{c}-0.007 * * * \\
{[0.002]}\end{array}$ & $\begin{array}{c}-0.009 * * * \\
{[0.001]}\end{array}$ & $\begin{array}{c}-0.009 * * * \\
{[0.001]}\end{array}$ \\
\hline Age Squared & $\begin{array}{c}0.000^{* * *} \\
{[0.000]}\end{array}$ & $\begin{array}{c}0.000^{* * *} \\
{[0.000]}\end{array}$ & $\begin{array}{c}0.000^{* * *} \\
{[0.000]}\end{array}$ & $\begin{array}{c}0.000^{* * *} \\
{[0.000]}\end{array}$ & $\begin{array}{c}0.000^{* * *} \\
{[0.000]}\end{array}$ & $\begin{array}{c}0.000^{* * *} \\
{[0.000]}\end{array}$ & $\begin{array}{c}0.000^{* * *} \\
{[0.000]}\end{array}$ & $\begin{array}{c}0.000^{* * *} \\
{[0.000]}\end{array}$ & $\begin{array}{c}0.000^{* * *} \\
{[0.000]}\end{array}$ & $\begin{array}{c}0.000^{* * *} \\
{[0.000]}\end{array}$ & $\begin{array}{c}0.000^{* * *} \\
{[0.000]}\end{array}$ & $\begin{array}{c}0.000^{* * *} \\
{[0.000]}\end{array}$ \\
\hline Medium-skilled & $\begin{array}{c}0.012^{* * *} \\
{[0.004]}\end{array}$ & $\begin{array}{c}0.013 * * * \\
{[0.004]}\end{array}$ & $\begin{array}{c}0.013 * * * \\
{[0.004]}\end{array}$ & $\begin{array}{c}0.018^{* * *} \\
{[0.006]}\end{array}$ & $\begin{array}{c}0.022^{* * *} \\
{[0.005]}\end{array}$ & $\begin{array}{c}0.022^{* * *} \\
{[0.005]}\end{array}$ & $\begin{array}{l}-0.006 \\
{[0.004]}\end{array}$ & $\begin{array}{c}-0.004 \\
{[0.004]}\end{array}$ & $\begin{array}{c}-0.004 \\
{[0.004]}\end{array}$ & $\begin{array}{c}-0.000 \\
{[0.006]}\end{array}$ & $\begin{array}{c}0.004 \\
{[0.005]}\end{array}$ & $\begin{array}{c}0.004 \\
{[0.005]}\end{array}$ \\
\hline High-skilled & $\begin{array}{c}-0.006 \\
{[0.006]}\end{array}$ & $\begin{array}{c}-0.004 \\
{[0.006]}\end{array}$ & $\begin{array}{c}-0.004 \\
{[0.006]}\end{array}$ & $\begin{array}{c}-0.051 * * * \\
{[0.009]}\end{array}$ & $\begin{array}{c}-0.048^{* * *} \\
{[0.008]}\end{array}$ & $\begin{array}{c}-0.047 * * * \\
{[0.008]}\end{array}$ & $\begin{array}{c}-0.029 * * * \\
{[0.007]}\end{array}$ & $\begin{array}{c}-0.025 * * * \\
{[0.007]}\end{array}$ & $\begin{array}{c}-0.025 * * * \\
{[0.007]}\end{array}$ & $\begin{array}{c}-0.065 * * * \\
{[0.009]}\end{array}$ & $\begin{array}{c}-0.064^{* * *} \\
{[0.008]}\end{array}$ & $\begin{array}{c}-0.063^{* * *} \\
{[0.008]}\end{array}$ \\
\hline Region of Origin Fixed Effects & Yes & Yes & Yes & Yes & Yes & Yes & Yes & Yes & Yes & Yes & Yes & Yes \\
\hline Year Fixed Effects & Yes & Yes & Yes & Yes & Yes & Yes & Yes & Yes & Yes & Yes & Yes & Yes \\
\hline State Fixed Effects & Yes & Yes & Yes & Yes & Yes & Yes & Yes & Yes & Yes & Yes & Yes & Yes \\
\hline State-specific Linear Trends & Yes & Yes & Yes & Yes & Yes & Yes & Yes & Yes & Yes & Yes & Yes & Yes \\
\hline Observations & 22,387 & 22,387 & 22,387 & 19,167 & 19,167 & 19,167 & 21,923 & 21,923 & 21,923 & 19,663 & 19,663 & 19,663 \\
\hline R Squared & 0.102 & 0.110 & 0.116 & 0.110 & 0.126 & 0.129 & 0.091 & 0.098 & 0.101 & 0.096 & 0.108 & 0.110 \\
\hline Mean of Dependent Variable & 0.085 & 0.085 & 0.085 & 0.144 & 0.144 & 0.144 & 0.092 & 0.092 & 0.092 & 0.152 & 0.152 & 0.152 \\
\hline
\end{tabular}

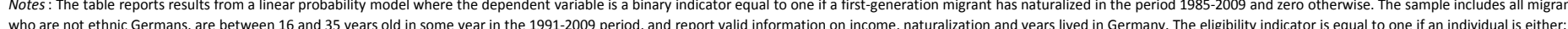
$16-22$ years old and has lived in Germany for at least 8 years; or b) is $23-35$ vears old and has lived in Germany for at least 15 years in the 1991-1999 period; and c) is $23-35$ years old and has lived in Germany for at least 8 years after 2000 . The first specification reports results for older guestworkers (or their family members) who arrived in Germany between 1976 and 1989 (men in columns (1)-(3), women incolumns (7)-(9)). The second specification shows results for more recent immigrants who arrived in Germany between 1990 and 2000 (men in columns (4)-(6) and women in columns (10)-(12)). The omitted region of origin are the traditional EU-15 member states; the omitted education category is low-skilled (no highschool or vocational

Source: Microcensus Pseudopanel (1985-2009). 
Table A7: Citizenship and Employment Stability

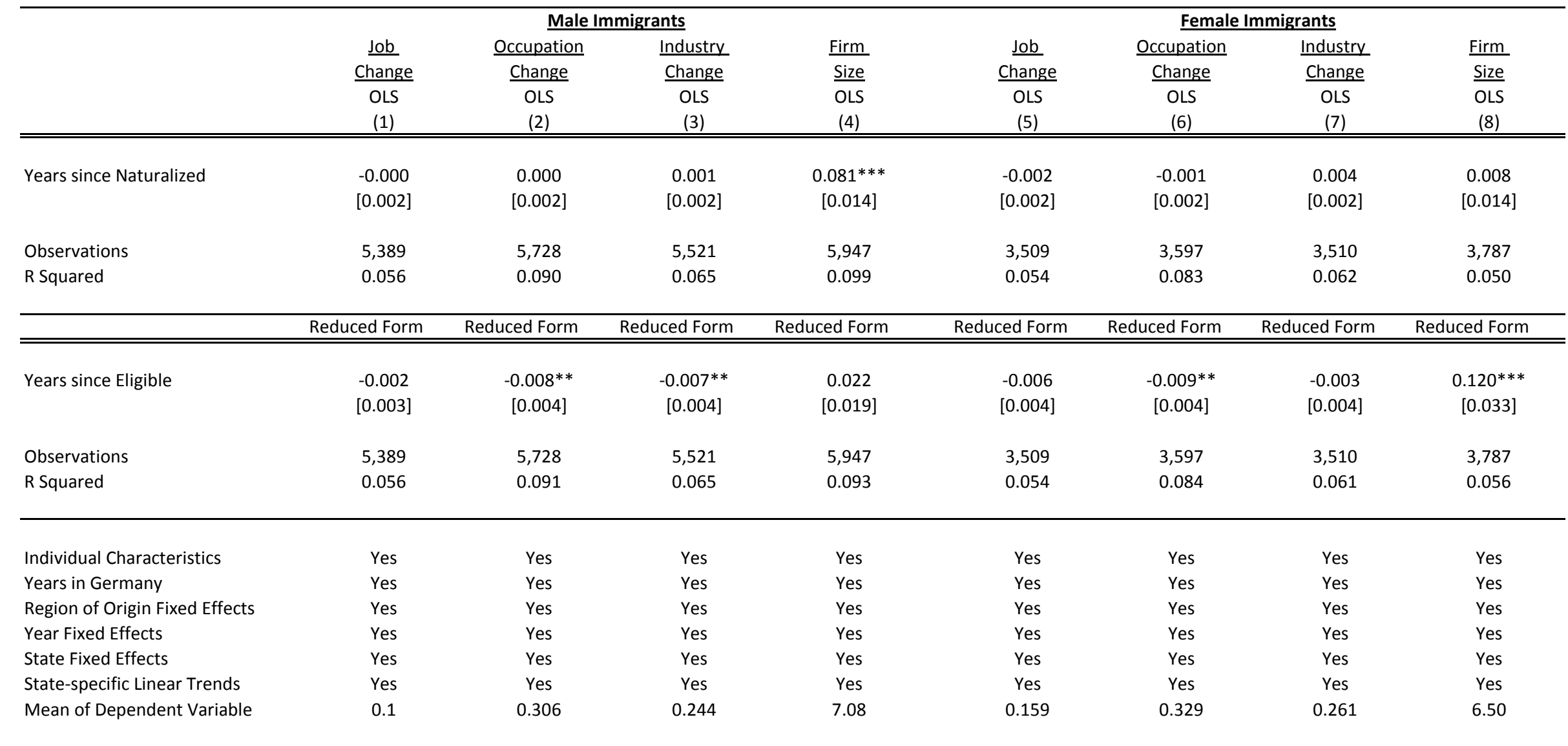

Notes : The table reports OLS (top panel) and reduced-form estimates (bottom panel) of the returns to citizenship for male and female immigrants in Germany. The dependent variables are whether a person switches jobs in the following year (columns (1) and (5)); whether a person switches her two-digit occupation in the following year (columns (2) and (6)); and whether a person switches her broad industry of employment (1-digit) in the following year (columns (3) and (7)). Finally, the dependent variable in column (4) and (8) is the size of the firm size an individual works in; the variable is categorical ranging from 1 (self-employed with no employees or working in a firm with less than 5 employees) to 10 (working in a firm with 2000 employees or more). The sample includes all immigrants who arrived in Germany between 1976 and 2000 and who were between 16-35 years old in some year in the 1991-2009 period. We exclude all ethnic Germans, i.e. immigrants with German ancestry who had faster access to German citizenship than regular immigrants. Years since naturalized denote the number of years since an immigrant reports naturalization. All specifications include the same individual chara level. Statistical significance *** $p<0.01 * * p<0.05 *$ * $<0.1$

Source : Socio-Economic Panel (1984-2009). 
Table A8: Eligibility and Pre-Policy Immigrant Characteristics (1984-1989)

\begin{tabular}{|c|c|c|}
\hline & $\frac{\text { Male Immigrants }}{(1)}$ & $\begin{array}{c}\text { Female Immigrants } \\
(2) \\
\end{array}$ \\
\hline \multirow[t]{2}{*}{ Employment } & 0.191 & 0.052 \\
\hline & [0.314] & {$[0.098]$} \\
\hline \multirow[t]{2}{*}{ Working Fulltime } & -0.008 & $-0.094^{*}$ \\
\hline & [0.009] & {$[0.053]$} \\
\hline \multirow[t]{2}{*}{ Overtime Hours } & 0.451 & -0.051 \\
\hline & [0.429] & {$[0.397]$} \\
\hline \multirow[t]{2}{*}{ Annual Hours Worked } & 46.931 & -80.961 \\
\hline & [96.278] & [88.514] \\
\hline \multirow[t]{2}{*}{ Log Monthly Wages } & 0.005 & -0.005 \\
\hline & {$[0.046]$} & [0.095] \\
\hline \multirow[t]{2}{*}{ Job in Service Sector } & $0.093^{*}$ & -0.019 \\
\hline & {$[0.056]$} & {$[0.060]$} \\
\hline \multirow[t]{2}{*}{ Job in Manufacturing } & $-0.112^{*}$ & -0.021 \\
\hline & [0.058] & {$[0.060]$} \\
\hline \multirow[t]{2}{*}{ Years of Education } & 0.119 & -0.249 \\
\hline & [0.198] & [0.141] \\
\hline \multirow[t]{2}{*}{ Education Abroad } & 0.038 & 0.012 \\
\hline & {$[0.027]$} & {$[0.034]$} \\
\hline \multirow[t]{2}{*}{ Speak Mother Tongue } & -0.026 & -0.044 \\
\hline & [0.055] & {$[0.062]$} \\
\hline \multirow[t]{2}{*}{ Write Mother Tongue } & 0.023 & -0.113 \\
\hline & [0.061] & [0.083] \\
\hline \multirow[t]{2}{*}{ Married } & 0.002 & -0.002 \\
\hline & [0.018] & {$[0.021]$} \\
\hline \multirow[t]{2}{*}{ Household Size } & -0.094 & $-0.369 *$ \\
\hline & [0.181] & {$[0.202]$} \\
\hline \multirow[t]{2}{*}{ Household Income } & 129.521 & 10.347 \\
\hline & [90.910] & [94.228] \\
\hline
\end{tabular}

Notes: The table reports estimates from a regression of the dependent variables (shown in the first column) on an indicator equal to one if an immigrant is eligible shortly after the 1991 reform (in 19911995); the indicator is zero for immigrants who got eligible somewhat later (1996-1999). The data are restricted to the pre-reform period (1984-1989). The sample contains first-generation immigrants who arrive in Germany between 1976 and 2000 and are 16-35 years old in the post-reform period (19912009). We exclude all ethnic Germans, i.e. immigrants with German ancestry who had faster access to German citizenship than regular immigrants. All regressions control for age, age squared, years in Germany, a linear and squared term of years spent in Germany, year and state fixed effects as well as state-specific linear trends. We also include 10 region of origin fixed effects (traditional EU countries, new EU entrants (EU-12), ex-Yugoslavia, Turkey, Middle East, Asia, Africa, North and South America, Russia and other former Soviet Union republics, other or no citizenship). Standard errors are clustered at the age $x$ arrival cohort level. Statistical significance: ${ }^{* * *} p<0.01, * * p<0.05, * p<0.1$

Source : Socio-Economic Panel (1984-1989) 
Table A9: Placebo Reforms

\begin{tabular}{|c|c|c|c|c|}
\hline & \multicolumn{2}{|c|}{ Male Immigrants } & \multicolumn{2}{|c|}{ Female Immigrants } \\
\hline & $\begin{array}{l}\text { Labor Force } \\
\text { Participation }\end{array}$ & $\begin{array}{c}\text { Log Monthly } \\
\text { Earnings }\end{array}$ & $\begin{array}{l}\text { Labor Force } \\
\text { Participation }\end{array}$ & $\begin{array}{l}\text { Log Monthly } \\
\text { Earnings }\end{array}$ \\
\hline Placebo Reform t-2 (1989) & $\begin{array}{r}-0.003 \\
{[0.014]}\end{array}$ & $\begin{array}{c}0.042 \\
{[0.027]}\end{array}$ & $\begin{array}{c}0.037 \\
{[0.029]}\end{array}$ & $\begin{array}{c}0.021 \\
{[0.052]}\end{array}$ \\
\hline Placebo Reform t-3 (1988) & $\begin{array}{c}0.017 \\
{[0.015]}\end{array}$ & $\begin{array}{c}0.034 \\
{[0.029]}\end{array}$ & $\begin{array}{l}-0.015 \\
{[0.026]}\end{array}$ & $\begin{array}{c}0.022 \\
{[0.051]}\end{array}$ \\
\hline Placebo Reform t-4 (1987) & $\begin{array}{c}0.013 \\
{[0.015]}\end{array}$ & $\begin{array}{c}0.042 \\
{[0.034]}\end{array}$ & $\begin{array}{c}0.016 \\
{[0.027]}\end{array}$ & $\begin{array}{c}0.012 \\
{[0.052]}\end{array}$ \\
\hline Placebo Reform t-5 (1986) & $\begin{array}{c}0.033^{* *} \\
{[0.016]}\end{array}$ & $\begin{array}{c}0.052 \\
{[0.035]}\end{array}$ & $\begin{array}{c}0.030 \\
{[0.029]}\end{array}$ & $\begin{array}{c}0.016 \\
{[0.060]}\end{array}$ \\
\hline Placebo Reform t-6 (1985) & $\begin{array}{c}0.059 * * * \\
{[0.018]}\end{array}$ & $\begin{array}{c}0.045 \\
{[0.042]}\end{array}$ & $\begin{array}{c}0.044 \\
{[0.033]}\end{array}$ & $\begin{array}{c}-0.063 \\
{[0.064]}\end{array}$ \\
\hline $\begin{array}{l}\text { Notes: The table reports coeffici } \\
\text { and the control variables used in } \\
\text { reforms but assumes that the ref } \\
1991 \text { reform period with the pre } \\
\text { education, year and state dumm } \\
\text { entrants (EU-12), ex-Yugoslavia, } \\
\text { or no citizenship). Standard error }\end{array}$ & $\begin{array}{l}\text { te regression of } t \\
\text { Placebo reform t- } \\
\text { nted in } 1989 \text { inste } \\
\text { od. All specificati } \\
\text {-specific trends. V } \\
\text { t, Asia, Africa, No } \\
\text { he age x arrival cc }\end{array}$ & $\begin{array}{l}\text { llates eligibility us } \\
\text { sample is restric } \\
\text { lude age, age squ } \\
\text { include region of } \\
\text { South America, } \\
\text { evel. Statistical sig }\end{array}$ & $\begin{array}{l}\text { he top row on th } \\
\text { esidency requiren } \\
\text { ars before } 2000 \text { to } \\
\text { ars in Germany, y } \\
\text { ed effects (traditi } \\
\text { d other former So } \\
* * * p<0.01, * * p\end{array}$ & $\begin{array}{l}\text { bo reform indicat } \\
\text { ules as in the actu } \\
\text { overlap of the po } \\
\text { Germany square } \\
U \text { countries, new } \\
\text { hion republics, oth } \\
{ }^{*} \text { p }<0.1 \text {. }\end{array}$ \\
\hline
\end{tabular}


Table A10: Additional Estimates of the Labor Market Returns to Naturalization

\begin{tabular}{|c|c|c|c|c|c|c|c|c|}
\hline & \multicolumn{4}{|c|}{ Male Immigrants } & \multicolumn{4}{|c|}{ Female Immigrants } \\
\hline & \multirow{2}{*}{\multicolumn{2}{|c|}{$\frac{\text { Employment }}{\text { OLS }}$}} & \multirow{2}{*}{\multicolumn{2}{|c|}{$\frac{\text { Log Monthly Earnings }}{\text { OLS }}$}} & \multirow{2}{*}{\multicolumn{2}{|c|}{$\frac{\text { Employment }}{\text { OLS }}$}} & \multirow{2}{*}{\multicolumn{2}{|c|}{$\frac{\text { Log Monthly Earnings }}{\text { OLS }}$}} \\
\hline & & & & & & & & \\
\hline & (1) & (2) & (3) & (4) & (5) & $(6)$ & (7) & (8) \\
\hline \multirow[t]{2}{*}{ Actually Naturalized } & -0.000 & -0.000 & 0.024 & 0.021 & $0.042^{*}$ & 0.032 & 0.045 & 0.022 \\
\hline & {$[0.018]$} & {$[0.018]$} & {$[0.028]$} & {$[0.027]$} & {$[0.024]$} & {$[0.024]$} & {$[0.059]$} & {$[0.058]$} \\
\hline \multirow[t]{2}{*}{ Years since Naturalized } & $0.006^{* * *}$ & $0.003^{*}$ & 0.005 & 0.001 & $0.007 * * *$ & 0.003 & $0.016^{* * *}$ & $0.009 * *$ \\
\hline & [0.002] & {$[0.002]$} & {$[0.003]$} & {$[0.003]$} & {$[0.002]$} & [0.002] & {$[0.004]$} & {$[0.004]$} \\
\hline Observations & 7,810 & 7,810 & 6,178 & 6,178 & 8,462 & 8,462 & 4,019 & 4,019 \\
\hline \multirow[t]{3}{*}{ R Squared } & 0.121 & 0.129 & 0.458 & 0.469 & 0.118 & 0.138 & 0.169 & 0.187 \\
\hline & \multicolumn{2}{|c|}{ Employment } & \multicolumn{2}{|c|}{ Personal Income } & \multicolumn{2}{|c|}{ Employment } & \multirow{2}{*}{\multicolumn{2}{|c|}{$\frac{\text { Personal Income }}{\text { Reduced Form }}$}} \\
\hline & Reduc & Form & Reduc & Eorm & Reduc & Form & & \\
\hline \multirow[t]{2}{*}{ Eligible for Naturalization } & $0.052^{* * *}$ & 0.008 & $0.058^{* * *}$ & 0.014 & $0.117^{* * *}$ & -0.002 & $0.113^{* * *}$ & 0.026 \\
\hline & {$[0.015]$} & {$[0.022]$} & {$[0.020]$} & {$[0.045]$} & [0.017] & {$[0.021]$} & [0.039] & {$[0.025]$} \\
\hline \multirow[t]{2}{*}{ Years since Eligible } & $0.008^{* * *}$ & -0.005 & $0.020 * * *$ & -0.003 & $0.009 * * *$ & $0.008 * * *$ & $0.027^{* * *}$ & $0.013^{* * *}$ \\
\hline & {$[0.002]$} & {$[0.003]$} & {$[0.003]$} & {$[0.007]$} & [0.002] & {$[0.003]$} & {$[0.005]$} & [0.003] \\
\hline Observations & 7,810 & 7,810 & 6,178 & 6,178 & 8,462 & 8,462 & 4,019 & 4,019 \\
\hline R Squared & 0.127 & 0.129 & 0.469 & 0.470 & 0.126 & 0.137 & 0.176 & 0.185 \\
\hline Individual Characteristics & Yes & Yes & Yes & Yes & Yes & Yes & Yes & Yes \\
\hline Years in Germany & No & Yes & No & Yes & No & Yes & No & Yes \\
\hline Region of Origin Fixed Effects & Yes & Yes & Yes & Yes & Yes & Yes & Yes & Yes \\
\hline Year Fixed Effects & Yes & Yes & Yes & Yes & Yes & Yes & Yes & Yes \\
\hline State Fixed Effects & Yes & Yes & Yes & Yes & Yes & Yes & Yes & Yes \\
\hline State-specific Linear Trends & Yes & Yes & Yes & Yes & Yes & Yes & Yes & Yes \\
\hline \multicolumn{9}{|c|}{$\begin{array}{l}\text { Notes: The table reports OLS (top panel) and reduced-form estimates (bottom panel) of the returns to citizenship. The dependent variables are whether a person is employed (columns (1)- } \\
\text { (2) and (5)-(6)) and the log monthly personal income (columns (3)-(4) and (7)-(8)). To test for the presence of level and slope effects, the specifications includes both an indicator for actual } \\
\text { naturalization and years since naturalization (in the top panel); or an indicator for eligiblity and the number of years of eligibility (in the bottom panel). The sample includes all immigrants } \\
\text { who arrived in Germany between } 1976 \text { and } 2000 \text { who were between } 16-35 \text { years old in some year in the } 1991-2009 \text { period. We exclude all ethnic Germans, i.e. immigrants with German } \\
\text { ancestry who had faster access to German citizenship than regular immigrants. All specifications include the same individual characteristics as earlier tables (age, education), current year } \\
\text { and state of current residence fixed effects as well as state-specific linear trends. We also include } 10 \text { region of origin fixed effects (traditional EU countries, new EU entrants (EU-12), ex- } \\
\text { Yugoslavia, Turkey, Middle East, Asia, Africa, North and South America, Russia and other former Soviet Union republics, other or no citizenship). The second specification (columns (2), (4), } \\
(6) \text { and (8)) includes a linear and squared term in the years since arrival in Germany. Standard errors are clustered at the age } x \text { arrival cohort level. Statistical significance: } * * * \text { p }<0.01,{ }^{* *} \\
p<0.05,{ }^{*} p<0.1 \text {. }\end{array}$} \\
\hline
\end{tabular}


Figure A1: Identification of Wage Effects

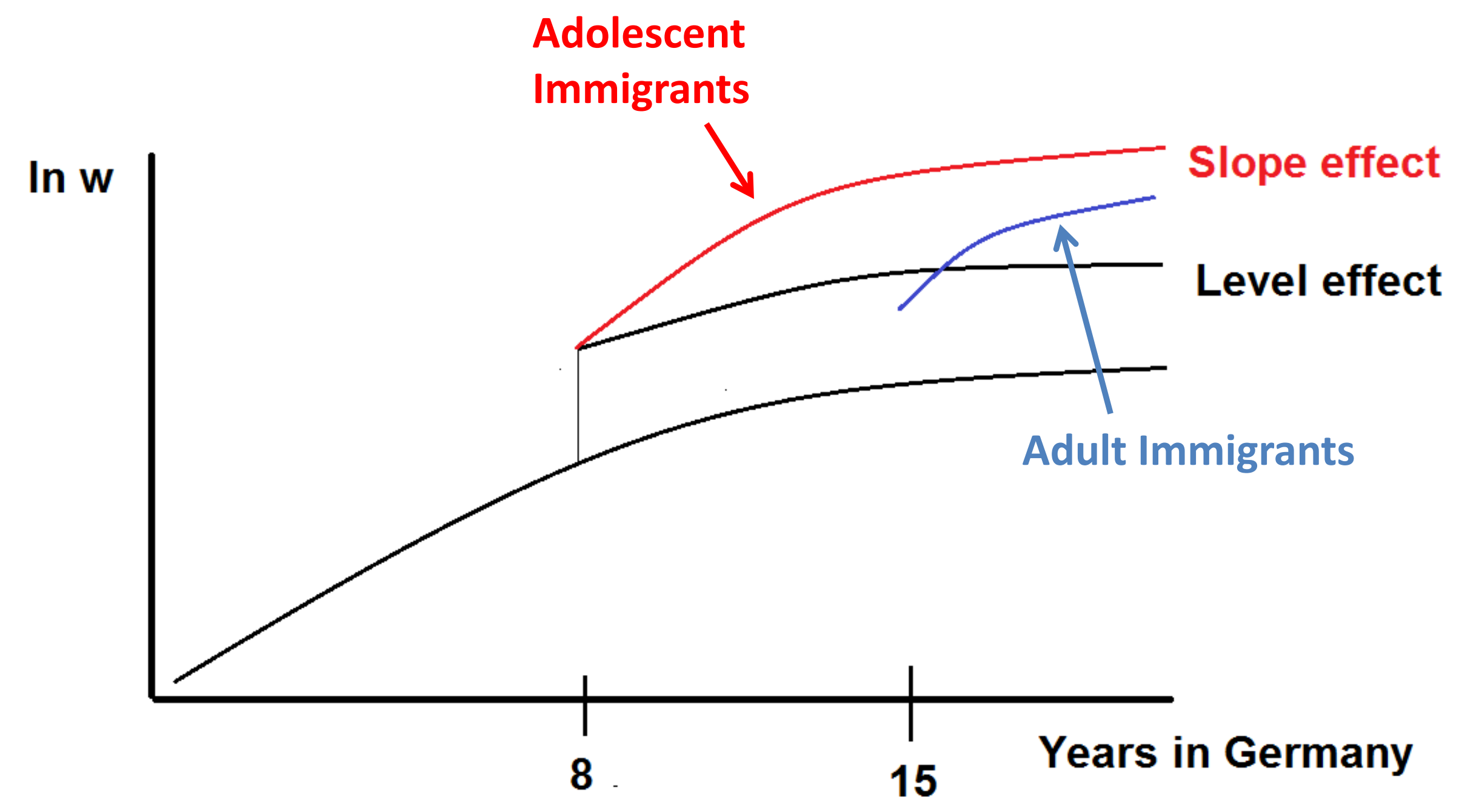

